P. WAGENAAR HUMMELINCK

\title{
ROTSTEKENINGEN VAN CURAC̨AO, ARUBA EN BONAIRE
}

\author{
DEEL III
}

Toen in het tweede deel van de 'Rotstekeningen van Curaçao, Aruba en Bonaire' de hoop werd uitgesproken dat de Bonaireaanse petrografieën van Spelonk en Onima spoedig als derde deel van deze documentatie zouden kunnen volgen, kon niet worden vermoed, dat de beschrijving van deze vindplaatsen zou moeten worden uitgesteld ten gunste van de publicatie van een aantal waarnemingen welke inmiddels door eilandbewoners waren verricht.

De grootste verrassing hierbij was een album - mij aangeboden door Ivan TJON Sie FAT, telegrafist te Oranjestad (Aruba) - dat een groot aantal foto's bevatte van mij nog onbekende Arubaanse rotstekeningen, benevens afbeeldingen van enkele bekende vindplaatsen welke zóveel duidelijker waren dan de reeds gereproduceerde, dat besloten werd ook deze in dit derde deel op te nemen.

Op Curaçao waren inmiddels door leden van de 'Natuurwetenschappelijke Werkgroep' nieuwe vondsten gedaan, welke - met nog enkele eigen waarnemingen - eveneens nog hierin werden verwerkt.

Ook in meer officiële kringen bestond een groeiende belangstelling voor de archeologie van onze eilanden, welke gepaard ging met een grotere waardering voor hetgeen aan landschappelijk schoons en merkwaardigs toeristen kon worden geboden. Een keurig wandelpad voert thans - door een opgeruimd en van lastige cactussen gezuiverd landschap - naar het reusachtige uitgeholde rotsblok van Ajó (A2), waarop met enorme letters 'Ajo Bar' is geschilderd. Andere vindplaatsen vervullen ons eveneens met zorg. Aan de uitbreiding van de steengroeve van Canashito, en het vliegveld op Hato, zijn de dichtstbijzijnde vindplaatsen reeds ten offer gevallen. 
Pastoor van KoolwiJK schreef in I885 (I, p. II), dat hij op Aruba "reeds op 27 plaatsen indiaansche opschriften" had ontdekt. Aanvankelijk was men geneigd aan te nemen, dat de meeste hiervan sindsdien wel verloren zouden zijn gegaan. $\mathrm{Na}$ de onderzoekingen van IvaN TJON SIE FAT weten wij echter dat dit niet het geval is. Diens veldwerk gaf meer resultaten dan wij durfden hopen, en zijn waarnemingen waren op een zo uitnemende wijze met foto's en korte, zakelijke aantekeningen gedocumenteerd, dat het mij een behoefte is hem, voor zijn bijdrage tot onze kennis van de Arubaanse prae-historie, op deze plaats hulde te brengen.

In $195^{8}$ heeft de 'Werkgroep' een Verjaardagskalender het licht doen zien, waarin tekeningen van een groot aantal petrografieën (waaronder nog onbekende van Santa Martha en Spelonk) als versiering van de kalenderbladen zijn afgedrukt.

HARTOG's grote werk over Curaçao dat zeer kortgeleden verscheen, geeft een overzicht van de Curaçaose rotstekeningen.

Uit de plaatselijke pers wisten wij reeds dat de chirurg Dr. HANS FERIZ, honorair medewerker van het Koninklijk Instituut voor de Tropen te Amsterdam, in mei 1954 een grote belangstelling heeft getoond voor de Arubaanse tekeningen (II, p. II8, Beurs 26. V. '54). In de beschrijving van zijn archeologische studiereizen Zwischen Peru und Mexico, welke in augustus 1959 verscheen, wijdt hij niet minder dan 38 bladzijden, en 3 uitslaande platen, aan Aruba en Bonaire. Het gedeelte dat op de Arubaanse rotstekeningen betrekking heeft wordt hieronder, volledigheidshalve, letterlijk en zonder commentaarovergenomen. FERIz' vlotte interpretaties zullen vele personen stellig meer bevallen dan het voorzichtige voorbehoud, dat de samensteller van deze documentatie ten aanzien van de verklaring der Antilliaanse petrografieën vooralsnog geboden acht. (Vgl. Fig. 2-4).

18. V. 1954. [p. 107] “... wir ... erreichen ... den 176 Meter hohen Berg [p. 108] Arikók unter dessen Granitkuppe sich Höhlen mit Felszeichnungen befinden; der Eingang zu den Höhlen ist hinter gewaltigen Granitblöcken verborgen. Die Höhlen selbst sind muschelförmig, nicht tief, aber wohl geeignet für eine primitive Behausung. Die Zeichnungen sind in mattroter und weisser Farbe ... angebracht und stellen unter anderem eine vierfingrige Hand dar, einen grossen Haifisch und vierfüssige Tiere, was nicht unbedingt gegen das präkolumbische Alter der Zeichnungen sprechen muss. Denn wenn es auch bei der Ankunft der ersten Europäer keine Säugetiere auf der Insel gegeben hat, so können die Indianer die Erinnerung daran vom nahen Festland mitgebracht haben. Sehr merkwürdig ist die Zeichnung einer menschlichen Figur, welche, wie man sagt, "die Sonne vom Himmel herab holt". (Abb. 2, Taf. I2 ). 


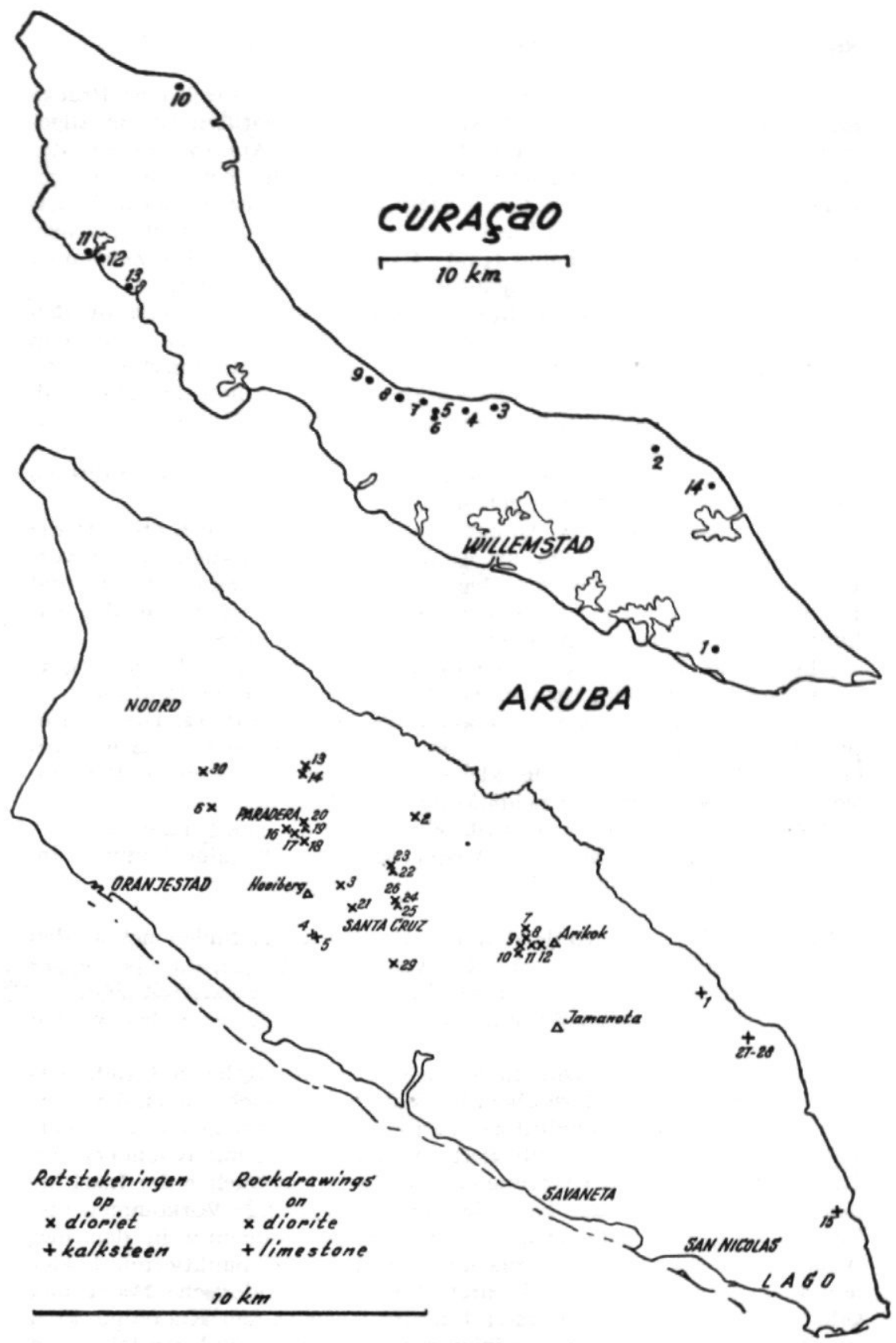

Fig. I. De ligging van 44 vindplaatsen van rotstekeningen op Curaf̧ao en Aruba; C I-I 4 en A I, 4-5, I 5, 27-28 op kalksteen, A 2-3, 6-14, 16-26, 29-30 op dioriet. Inscripties (petroglyphen) vindt men alleen bij $\mathrm{C}_{4}$ en $\mathrm{C}_{14}$; op de andere vindplaatsen komen alleen tekeningen (petrographiën) voor.

Fig. I. Index maps of the islands of Curafao and Aruba showing sites at which rude linear designs occur, painted (petrographs) on limestone rock (C I-I3, A I, 4-5, I5, 27-28) or diorite (A 2-3, 6-1 4, 16-26, 29-30), and engraved (petroglyphs) in weathered dripstone $\left(\mathrm{C}_{4}, \mathrm{I}_{4}\right)$. 
Abb. I, Taf. 12 zeigt konzentrische weisse Kreise durch eine Brücke miteinander verbunden. Die Wiederholung der Konturen ist ein allgemeines Kennzeichen der Ornamentik der Indianer Amazoniens und der Guyanas. Aber hier ist der grössere Kreis offen, der Kleinere Ganz geschlossen; auch die verschiedene Anzahl der Kreise ist gewiss nicht zufällig (4 und 6 Kreise mit 5 Linien verbunden. Die Deuting ist unsicher: Sonne und Mond? Mutter und Kind? Mann und Frau? - Die Zeichnung kommt zwei Mal in verschiedenen Grössen in der Höhle vor.

Abb. 2, Taf. 12. Die Bedeutung dieser Zeichnung ergibt sich aus den von der Kreisscheibe links oben und dem Bogen rechts unten ausgehenden Strahlen. Hier ist unzweifelhaft eine Sonnen- und Mondmythe dargestellt. Der Mann scheint die Sonne werfen zu wollen, er holt sie nicht herab greift auch nicht nach ihr, sondern schiebt sie in den Himmel - auf dass sie ihre Bahn beschreibt.

Abb. 3, Taf. 12. Es ist bewundernswert, wie gut hier die charakteristische Kontur der Haifisches getroffen ist.

[p. 109] Abb. 4, Taf. 12. An europäische Felszeichnungen erinnert die Zeichnung eines Vierfüsslers, die wohl geeignet ist Diskussionen hervorzurufen. Der Kopf ist der eines Ameisenbären oder Tapirs, Schwanz und Beine passen aber eher zu einem Pferd, das den Indianern vor der Ankunft der Europäer jedoch unbekannt gewesen sein muss.

Abb. 5, Taf. 12. scheint der Abdruck einer Bärentatze oder einer vierfingrigen Hand zu sein, ist aber zweifelhaft bezüglich der Deutung.

Eine merkwürdig expressive Figur zeigt Abb. 6, Taf. 12. Die anthropomorphen Hände deuten auf einen Maskentragenden Menschen bei einer Beschwörungsszene. Die kleine Figur erinnert an einem Pinguin, sie könnte aber auch eine Schildkröte darstellen.

Abb. 7, Taf. 12 ist eher ein Fish oder Wurm als eine Schlange.

Abb. 8, Taf. 12 stellt einen Wasservogel dar. Pinguine kommen im Karibischen Meer nicht vor".

“... Fontein .... Im vordersten Teil der Grotte ... finden sich an den glatt- [p. Iro] gewachsenen Wänden viele Zeichnungen, die aber leider zum grossen Teil verwischt und von Besuchern ... verkritzelt sind.... Guadirikiri ... Indianer-Zeichnungen sind hier nicht gefunden worden ..."

19. V. 1954. "Auf Arikok finde ich eine zweite Höhle mit Indianerzeichnungen, die ich gestern übersehen habe. Wir besuchen auch die Grotten von Fontein und Guadirikiri ... Bei den Zeichnungen von [p. III] Fontein (die bereits 1885 publiziert wurden) scheint mir besonders ihre Lage an und über dem Ursprung einer der seltenen Quellen der Insel bedeutsam. Mit dieser Lage kann das besonders häufige Vorkommen von Wasser-Symbolen (Schlangenlinien und Spiralornamente) in den hier befindlichen Petrogrammen zusammenhängen. Die punktierten Felder und manche geometrischen Figuren dürften eine siderische Bedeutung gehabt haben. Das gilt in erster Linie von den in den Knotenpunkten von Netzen und durch gerade Linien miteinander verbundenen Rhomben und Ovalen mit Punkten oder kleine Kreisen in ihrer Mitte, die an die "Sternenaugen" der mexikanischen Bilderhandschriften erinnern".

2o. V. 1954. "Es gibt Hunderte von Höhlen und Grotten auf Aruba und nur ein kleiner Teil davon ist auf das Vorhandensein von Felsbildern 

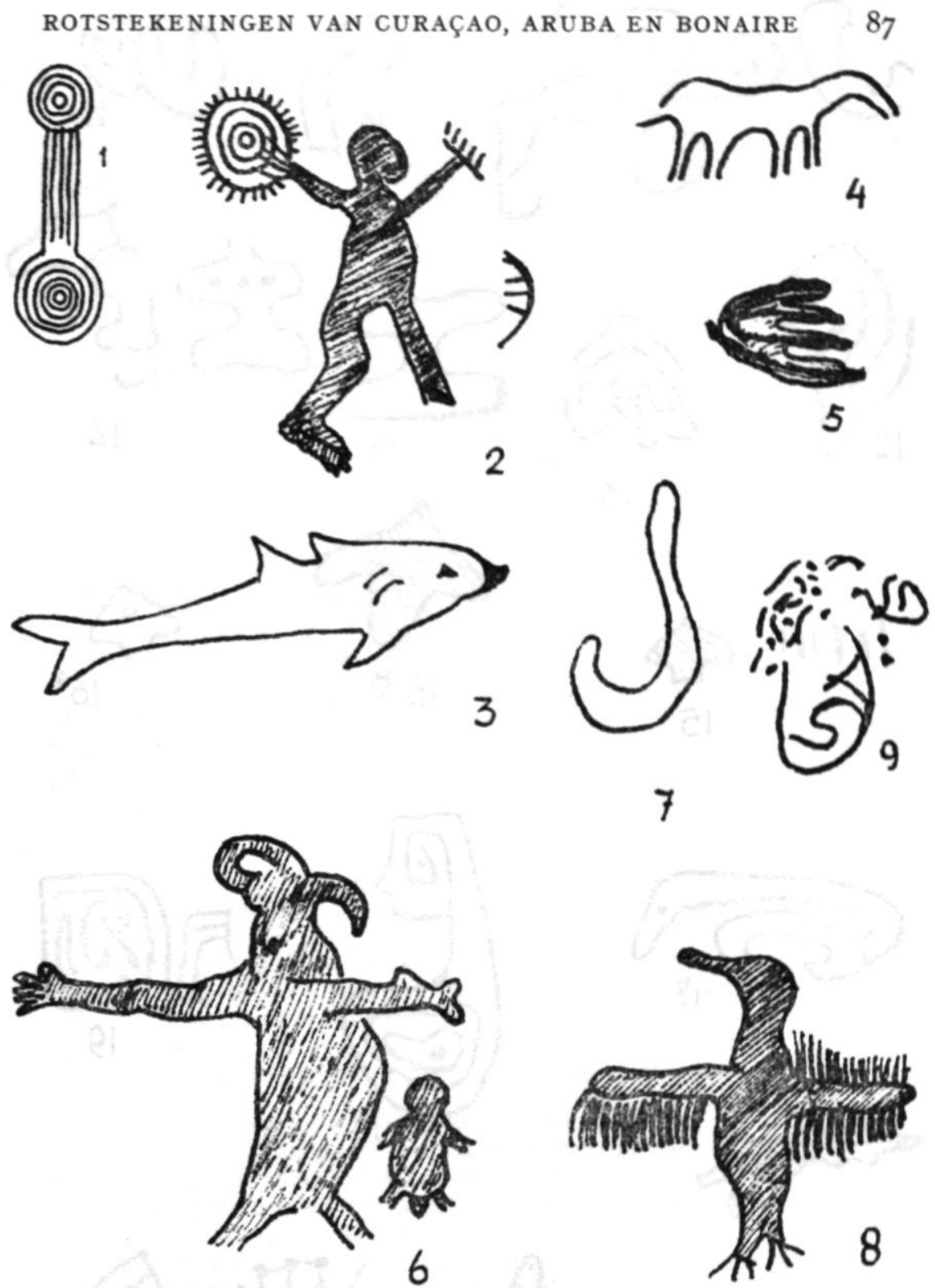

Fig. 2. Rotstekeningen van Aruba, zoals zij door FERIz in 1949 werden afgebeeld. (Taf. I2).Zie het onderschrift van fig. 4

Fig. 2. Rock drawings in Aruba, as sketched by FERIz, 1949. See Fig. 4. 

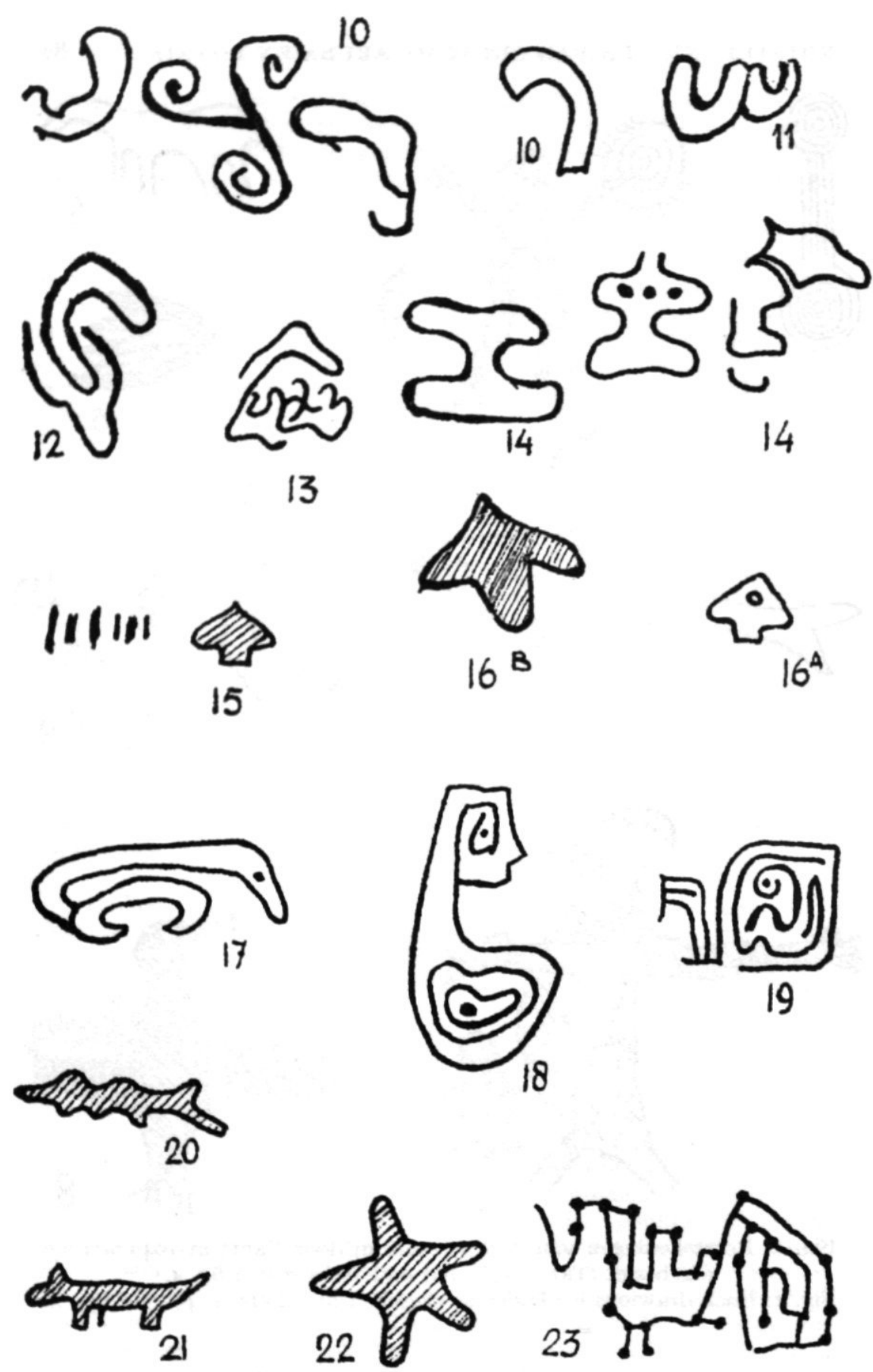

Fig. 3. Rotstekeningen van Aruba,zoals zij door FERIz in 1949 werden afgebeeld. (Taf. 12) Zie het onderschrift van fig. 4.

Fig. 3. Rock drawings in Aruba, as sketched by FERIZ, 1949. See Fig. 4. 


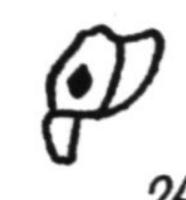

24

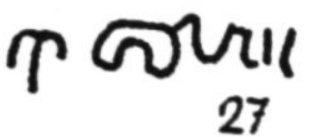

27

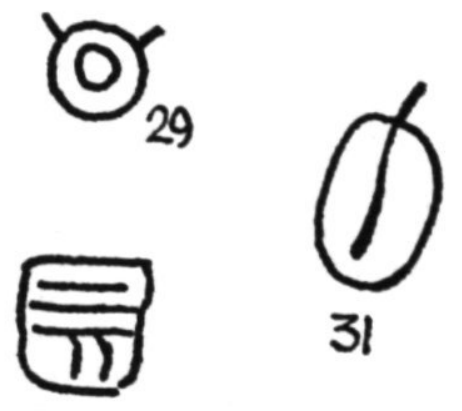

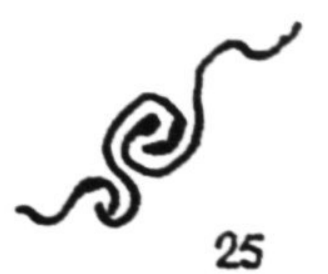

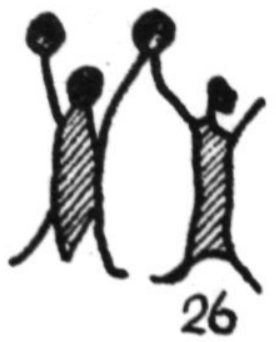

\section{0}

Fig. 4. Rotstekeningen van Aruba, zoals zij door FerIz in 1949 werden afgebeeld. (Taf. 13).

Fig. 4. Rock drawings in Aruba, as sketched by FerIz, 1949.

Figs. $2-4: \mathrm{I}=7 b ; 2=7 e, g ; 3=82 ; 5=8 x_{5} ; 6=820,22 ; 8=8 x 6$; $9=4 a ; 10=4 c ; 11=$ s.n., see I fig. I1 $; 12=4 d ; 14=$ s.n., see I fig. II; $15=5 h ; 16=5 g ; 18=5 e ; 19=5 k ; 20=5 m ; 21=5 r ; 22=5 j ; 23=$ $5 s ; 24=5 t ; 25=4 b ; 26=5 i ; 27=5 q ; 29=5 l ; 30=5 n$.

untersucht worden. ... Canashito. An der Steilwand ... südlich der Seroe Bientoe ... Arbeiter eines nahen Kalksteinbruches .... zeigen mir bereitwillig einen recht halsbrecherischen Pfad zu der Oberhalb der letzten Sprengstelle liegenden Höhle, die so gut verborgen ist, dass ich sie nur durch Zufall finden konnte ... [112] ... am Eingang etwa mannshoch und verengt sich trichterförmig. Nahe der Offnung befinden sich am Gewölbe und an den Seitenwänden sehr merkwürdige Indianerzeichnungen in braunroter Farbe. Nördlich anschliessend befindet sich eine zweite, kleinere Höhle, ebenfalls mit Spuren alter Zeichnungen - Punkten und Strichen - alle in derselben, matt braunroten Farbe. Die Zeichnungen, die einen Zusammenhang zeigen, versuche ich zur Ergänzung der Bilder von Martin und von Wagenaar Hummelinck zu kopieren.

Die Bedeutung der Zeichen $4^{-14}$, Taf. 12 ist völlig unklar; möglicherweise sind sie unvollständig erhalten und ist ihre Position zu einander 
wichtig. Auffallend ist das häufige Vorkommen von C-förmig gebogenen wurmartigen Figuren (Abb. Io, I1, 12, Taf. 12). Unter diesen befinden sich die Zeichen I4 von denen die linke an indianische Fischsymbole erinnern. Vermutlich zoomorph sind die Zeichen 15, 16, 17, Taf. 12 und 24, Taf. 13: Rochen, Vogel und Ameisenbär. Zeichen 15 könnte die Mitteilung erhalten, dass 6 Rochen gesichtet und gefangen wurden. Die Deutung von 17 ist ganz willkürlich und vor allem von dem Augenpunkt und dem Umriss der ganzen Figur diktiert, vielleicht nur die zufällig Folge der Verdoppelung einer wurmartigen C-Figur. Sehr charakteristisch ist dieses indianische Stilelement der Wiederholung der Konturen bei der vermutlich anthropomorphen Figur (No. I8), die einen hockenden Menschen darstellen könnte, sowie bei der Zeichnung No. 19, in der ich ebenfalls ein anthropomorphes Motiv vermute; die labyrinthartige Zeichnung No. 23 deutet auf eine siderische Konstellation. Die deutlich zoomorphen Zeichen 16B, 20, 21, 22, die einen ganz anderen Stil zeigen, rechtfertigen die Annahme, dass die geometrischen Figuren einen abstrakten Sinn hatten und nicht nur Symbole oder Stilisierungen von Gegenständen und Lebewesen waren. Die Menschen die diese Zeichnungen machten, waren sehr gut im Stande, die Konturen von ihnen bekannten Dingen naturgetreu zu reproduzieren. Das erweist sich auch [p. 113] in der hochinteressanten Zeichnung No. 26, Taf. 13, die an den Mann mit der Sonne in der Höhle von Arikok erinnert und keiner Erklärung bedarf. Sicherlich handelt es sich hier nicht um sinnlose Spielereien sondern auch bei den uns ganz unverständlichen Zeichen um Manifestationen einer Magie. Deshalb sind die Höhlen in denen die Felszeichnungen sich befinden, als Kultplätze zu bezeichnen. Wenn die Urbevölkerung überhaupt in Höhlen gewohnt hat, was bei dem günstigen Klima und der Abwesenheit von wilden Tieren und feindlichen Stämmen unwahrscheinlich ist, dann hat sie andere Höhlen bewohnt als die mit Zeichnungen geschmückten. Grabungen in den Höhlen sind noch nicht versucht worden. In Canashito, Arikok und in der Fonteingrotte besteht der Boden aus gewachsenem Fels. - Die prähistorische Siedlung der Leute von Canashito vermute ich am Fuss des Grottenberges. - Die restlichen in der Höhle von mir kopierten Zeichen sind: Abb. 27, Taf. 13, die einer griechischen Inschrift ähnelt; Abb. 28, Taf. 13 ist eine horizontale Reihe von 17 kurzen parallelen Strichen. Abb. 25, 29, 30, 31, Taf. 13 gebe ich hier ohne Kommentar, das doch nur willkürlich und phantastisch sein könnte. An jedem der von mir besuchten Fundplätze haben die Petrogramme ihren eigenen Charakter.

In Fontein überwiegen die abstrakten, kurvilinearen Zeichnungen (geometrische Figuren, Netzmuster, Schlangenlinien und Spiralen, einzeln und zu komplizierten Zeichen zusammengefasst). Abgesehen von zwei braunroten Handabdrücken, fehlen naturalistische, biomorphe Zeichnungen und nur in ganz wenigen Figuren sind stilisierte Abbreviaturen von Tieren zu erkennen.

In Arikok dagegen dominieren anthropo- und zoomorphe Figuren, die oft naturalistisch in sehr expressiven Haltungen dargestellt sind.

In den kleinen Höhlen der Seroe Canashito steht der Stil der Petrogramme dem von Fontein nahe. Wohl finden sich hier einzelne Menschen und Tierfiguren, [p. 114] aber diese sind schematisch mit sparsamen Konturen ausgeführt oder nur als Silhuetten angedeutet. Häufiger kommen 
jedoch abstrakte Zeichnungen vor, die denen von Fontein ähneln. Spezifisch für die Seroe Canashito sind wurmartige, C-förmige gekrümmte Zeichen.

Allen Fundplatzen gemeinsam sind Reihen gerader Striche, unregelmässige punktierte Flächen und die typisch aruakischen, ornamentalen Perseverationen, Verdopplungen wichtiger Konturen, besonders der Umrisse polygonaler und elliptischer Felder, die meist punktiert und netzförmig unterverteilt sind.

[p. II 5 ] Oberhalb dieser Höhle finde ich in einer kleineren, flacheren Aushöhlung wieder indianische Zeichnungen; es sind Vogelsymbole, Spiralen und einfache geometrische Figuren".

21. V. 1954. "Nachmittags mit [p. Ir 7] den Herren Müller, Hartog und De Wit zur Höhle von Canashito ... die Indianerzeichnungen werden photographiert ..."

\section{BESCHRIJVING VAN VINDPLAATSEN OP ARUBA}

\section{(A 3) Piedra Plat (Fig. 5, 39)}

Enkele mooie foto's van de Heer Ivan TJon SiE FAT - in oktober 1958 vervaardigd - stelden mij in staat een beter beeld te geven van de schilderingen op het bekende, uitgeholde blok kwartsdioriet bezuiden het kerkje van Piedra Plat, waarover in Deel I (p. 35) aan de hand van enkele tekeningen reeds mededelingen zijn gedaan. [In I, fig. $3 \mathrm{I}$ moet $c$ in $e$ en $d$ in $t$ worden veranderd.]

\section{(A 6) Tanki Leendert}

Aan de Heer E. BARTELs was reeds geruime tijd het voorkomen bekend van tekeningen in een diepe uitholling van een groot, alleenliggend diorietblok, omstreeks $600 \mathrm{~m}$ noordoostelijk van Tanki Leendert (A6), op een perceel dat thans behoort aan Lino de La M. Paula. In 1955 bleek de opening van deze holte reeds door een keurig gemetseld muurtje, voorzien van een deurtje en raampjes, te zijn gesloten. De Heer TJON SiE FAT vond, in mei $\mathbf{r} 96 \mathrm{I}$, in deze als berghok dienende ruimte, nog slechts op één plaats sporen van een verbleekte tekening.

$$
\text { (A 7-9) Arikok (Fig. 6, 40-46) }
$$

De beschrijving van de vindplaatsen bij Rooi Arikok (Deel II, p. 98-1oo, fig. II-19, 33-4I) moge hier worden aangevuld met enkele foto's van I. TJon SiE FAT, waarop de meest belangwekkende figuren veel duidelijker zijn waar te nemen dan op de in Deel II (fig. 33-4I) gegeven afbeeldingen.

Enkele figuren in een aparte lage holte van A8 (II, p. I0o, fig. II, 20), welke reeds door PINART op Planche 2 fig. 4 (links boven $=\mathrm{A} 8$ 24, rechts boven $=\mathrm{A} 8$ 25) waren aangeduid, konden thans naar foto's worden getekend.

De vogel $\mathrm{A} 826$ bevindt zich links van A 88 .

De in Deel II onder A8 24 vermelde sikkelvormige figuren (II, p. 1oo, fig. I8) zijn bij vergissing als voorkomende bij Arikok genoemd; in werkelijkheid zijn zij te vinden op het blok van Ajó (A2), dat in Deel I is behandeld.

Het blok met A9 ligt ongeveer 60 meter ten zuiden van A8. 
De eerste vindplaats (A7) werd door de bewoner van een huisje in Rooi Arikok aangeduid als 'Cudi Helena' (in verband met een verhaal over een meisje dat daar had gewoond); de tweede (A8) werd door hem 'Cudi Grandi' genoemd. In de oostwand van dit diorietblok staat een Mariabeeldje.

$$
\text { (A I0-12) Arikok (Fig. 6-7, 47) }
$$

Op hetzelfde terrein van Arikok liggen nog drie andere blokken welke resten van roodbruine tekeningen vertonen.

Een alleen-liggende diorietklomp, A ro, 300-400 meter zuid-zuidwestelijk van A9, heeft aan de zuidzijde een holte van ruim 2 meter hoog, bijna 2 meter breed en omstreeks 4 meter diep. In deze ruimte bevinden zich resten van een bruinrode beschildering, waarin men, met enige verbeelding, een menselijke figuur zou kunnen herkennen (Aro a). Van de nevenstaande figuren $(b-d)$ is door afschilfering van het gesteente weinig meer over.

Ongeveer 50 meter ten zuiden van A8 ligt, deel uitmakend van de trankeer, een ander diorietblok, Arr. Het heeft eveneens een uitholling op het zuiden, waarin enkele figuren zijn te herkennen welke reeds door PINART werden afgebeeld: II, Planche 6 fig. 9 links boven $=\operatorname{ArI} a$; rechts onder $=\operatorname{ArI} f$.

In dezelfde trankeer ligt, ongeveer 20 meter zuidwestelijk van AII "een nog iets kleiner blok, met een uitholling van ongeveer een meter diep en breed" (II, p. roo) waarin enkele onduidelijke bruine strepen en vlekken zijn waar te nemen: Ar2.

Deze vindplaatsen van Arikok werden door I. TJON SiE FAT in oktober 1958, februari en maart 1959 onderzocht, waarbij grote bulp werd ondervonden van de onderwijzers ORLANDo FERROL en DOMINico TROMP.

$$
\text { (A I3-I4) Babijn (Fig. 8-9, 48-49) }
$$

In het kwartsdiorietlandschap benoorden Oranjestad ligt in het bekende goudgraversgebied bij de Kristalberg, niet ver achter het woonhuis Babijn 12 - op een terrein toebehorende aan Minister W. F. M. Lampe een langwerpig blok van ongeveer ro meter lengte en 4 meter hoogte. Aan de zuidwestzijde vindt men een vrij ondiepe holte van ongeveer 2,70 meter breed en 2,25 meter hoog, met een duidelijk afschilferende wand waarin een klomp zwartachtig gesteente is uitgeprepareerd. Op deze wand ziet men nog de resten van een zestal tekeningen (Á13) van een roodachtige kleur, waarvan er slechts drie duidelijk genoeg waren om te worden afgebeeld (Fig. 8). Ar $3 a$ en $b$ liggen links van de donkere, uitstekende steenbrok, $30 \mathrm{~cm}$ van elkaar; Ar $3 c$ ligt rechts daarvan, $2 \mathrm{~m}$ van $\mathrm{I}_{3} a$ verwijderd. Duidelijke resten van een andere tekening bevinden zich in een kleine holte, ongeveer $30 \mathrm{~cm}$ links van $13 a$.

Westelijk van $\mathrm{Ar}_{3}$ ligt een ander diorietblok van ongeveer $5 \mathrm{~m}$ breed en $2,5 \mathrm{~m}$ hoog, met uithollingen aan de zuidwestelijke zijde, over nagenoeg de gehele breedte. In deze holte liggen een groot aantal verweerde tekeningen van een rode en roodbruine kleur, te onduidelijk dan dat zij goed konden worden afgebeeld. De roodgekleurde figuren vallen het meeste op en maken de indruk van later datum te zijn. 
Op hetzelfde perceel ligt, geheel vrij, een langwerpig diorietblok, waarop, in een kleine, ondiepe holte aan de zuidwestzijde, onduidelijke resten van rode tekeningen werden aangetroffen.

Mooiere tekeningen vindt men echter in de grote, ruime verweringsholte van een diorietblok ten zuiden hiervan (Ar4; Fig. 9, 48). Deze uitholling is reeds zo diep geworden dat men de indruk krijgt dat het blok nog slechts bestaat uit een dikke schil, welke reeds twee gapende scheuren vertoont, terwijl er onlangs ook al een stuk van de rand is afgebroken (links op Fig. 49).

Een smalle zone, vlak boven de grond, waar de wand in latere tijden het minst is afgeschilferd, toont ons nog resten van rotstekeningen, die vroeger stellig vrijwel de gehele wand moeten hebben bedekt. Het duidelijkste groepje, aan de linkerzijde, werd op Fig. 9 en 48 afgebeeld.

Deze vindplaatsen bij Babijn werden door I. TJON SIE FAT in december I958 (Ar3) en januari 1959 (Ar4) ontdekt en gefotografeerd.

\section{(A I5) Boca Grandi (Fig. I0)}

In 1955 had ik vergeefs getracht de rotstekeningen te vinden, welke, volgens mededeling van de onderwijzer J. C. vAN DEN BERGH, in de brandingsnis van het middenterras bij Boca Grandi aanwezig zouden zijn. I. TJON SiE FAT toonde mij thans enkele foto's van deze bruinachtig rode figuren, zoals hij ze op dezelfde plaats, 'Grapefield', zowel in de brandingsnis als in hiermede samenhangende ondiepe grotten, soms wel ter hoogte van $2 \frac{1}{2} \mathrm{~m}$ had gevonden. Gezien de ongunstige plaats - op de windzijde van het eiland, dicht bij de kust in een met zout bezwangerde atmosfeer - mag men er zich over verwonderen dat van deze tekeningen, die vroeger een zeer veel grotere oppervlakte moeten hebben bedekt, nog sporen konden worden gevonden.

Opvallend is de overeenkomst met de figuren van Quadirikiri (A27) - waar zij onder soortgelijke omstandigheden zijn te vinden - en van Fontein (AI); en ook hier komen dezelfde vreemd-getekende handafdrukken voor.

Deze vindplaats bij de 'Sea Grape Grove' werd door I. TJon Sir Fat in februari 1959 onderzocht.

\section{(A I6-I9) Paradera (Fig. II-I4, 50-52)}

In het diorietlandschap van Paradera liggen, op het perceel van Juanito Laclé, No. 149, vlak bij de oostelijke grens, een aantal grote blokken. Een hiervan, een kolossaal plat blok, ligt schuin tegen een andere steenklomp aan, en biedt aldus aan de westelijke zijde een goede schuilplaats voor mens en dier (Fig. 5I). Aan deze zijde van het schuinstaande blok bevindt zich een ondiepe verweringsholte van $\frac{3}{4} \mathrm{~m}$ breedte en $2 \mathrm{~m}$ hoogte (Ar6), waarin een achttal bruin-rode tekeningen zijn aangebracht. Vier daarvan zijn nauwelijks herkenbaar; de anderen zijn echter vrij gaaf gebleven. De grootste is mooi van vorm en met een vaste hand gemaakt (Ar6e $e$ ).

Op perceel Paradera No. 16r, van Placido Croes, ligt een diorietblok van ongeveer 5-6 m doorsnede, met aan de westkant een diepe verweringsholte van ongeveer $1.2 \mathrm{~m}$ hoogte en $2.3 \mathrm{~m}$ breedte. Naast het blok ligt een metersgrote klomp steen welke vroeger van dit blok is afgebroken, 
en de voortzetting vormde van het dak van deze holte. In deze holte ziet men een vijftal beschilderingen in een bruin-rode kleur, waarvan er drie (Ar7 $a-c$ ) tamelijk goed bewaard zijn gebleven. Hieronder zijn er, over een strook van ongeveer $50 \mathrm{~cm}$, nog resten zichtbaar van een of meer, waarschijnlijk oudere, oranjekleurige tekeningen $\left(\operatorname{Ar}_{7} d-e\right)$, waarover één der drie duidelijke bruinrode figuren $(c)$ schijnt te zijn geschilderd.

Vlak bij de grond zijn er verder nog schamele resten van bruinrode beschildering, ter breedte van $73 \mathrm{~cm}$, terwijl in een kleine holte, rechts, nog iets van een oranje-rood motief te bespeuren is.

Niet ver van dezelfde vindplaats, op hetzelfde perceel, ten zuidoosten van de woning van Placido Croes, vinden wij weer tekeningen in een beschuttende uitholling van een diorietheuveltje, dat bezig is tot een stapel losse blokken te verweren (Ar8). Deze keer geen ornamenten, maar figuren die met enige goede wil als symbolen zouden kunnen worden verklaard. De 'kikkerfiguur' (a) zit op het plafond van een kleine uitholling, van $\mathrm{I}, 4 \mathrm{~m}$ breed en $\mathrm{I}, 5 \mathrm{~m}$ hoog, links in dezelfde grote holte; de 'poten' hebben drie tenen; als 'kop' zou een bruin-rood, verbleekt vlekje moeten worden opgevat. Mensen met veel fantasie zien in fig. $b$ een beest met opgekrulde staart (aap of schorpioen). De oranjerode zon $(c)$ geeft minder aanleiding tot speculaties.

En tenslotte vinden wij op Paradera, ten noordoosten van de woning van Yarzagaray, in een grote holte op het Westen van $2,15 \mathrm{~m}$ breed en I,9 $\mathrm{m}$ hoog van een alleenliggend diorietblok, nog tekens (Ar9). Vijf daarvan waren zo duidelijk dat zij konden worden afgebeeld.

$$
\text { (A 20) Casibari (Fig. 16, 53-54) }
$$

Enkele honderden meters ten noordoosten van AI8, 500-60o m ten noorden van Casibari, liggen enkele losse diorietblokken met holten op hun zuidwestelijke kanten. Eén daarvan (de rechtse op fig. 53) heeft negen rode, duidelijke tekeningen: A2o.

De tekens van Paradera en Casibari werden door I. TJON Sie FAT in november 1958 en februari 1959 gevonden en gefotografeerd. Hij was daarbij dikwijls in gezelschap van H. A. D. Stenzen, waarbij JUAN Ismael CroEs hem tot gids diende.

\section{(A 2I) Seroe Noka (Fig. I5)}

Aan de voet van de zuidelijke helling van het uit kwartsdioriet bestaande heuveltje tussen Santa Cruz en de Hooiberg, dat als Seroe Noka bekend staat, ligt een rotsblok met een uitholling van ongeveer $2 \mathrm{~m}$ breedte. De ingang is bijzonder laag geworden, doordat hierin een hoop grond was opgeworpen door een naar schatten gravende persoon, die hier slechts 'waardeloze' scherven had gevonden. Deze vindplaats is zeer dicht gelegen bij het 'urnenveld' van Santa Cruz, waar reeds verschillende malen met veel succes is gegraven.

Op het plafond van deze uitholling bevindt zich aan de voorzijde een groepje samenhangende tekeningen van een roodachtige kleur, terwijl meer achterin een figuur $(c)$ staat welke bruinachtig rood is. Volgens I. TJon Sie FAT, die deze vindplaats in december 1958 ontdekte, en de tekeningen fotografeerde, moet deze laatste tekening (en misschien ook 
wel de andere) worden gezien als symbool voor een vogel - mede ook, omdat de onderzijde schijnt te zijn opgebouwd uit een aantal lijnen welke als staartpennen zouden kunnen worden gezien.

\section{(A 22-23) Shabururi (Fig. I7, 55)}

Te Shabururi - even ten noorden van Siribana - vond I. TJON SIE FAT enkele diorietblokken met tekeningen, doch de meeste waren zodanig verweerd, dat het niet mogelijk was er een goede afbeelding van te geven.

Nog enigszins duidelijk waren de tekeningen op een blok van ongeveer Io $\mathrm{m}$ breedte bij 2,5 $\mathrm{m}$ hoogte, waarin zich op het zuidwesten een uitholling bevond van $2 \mathrm{~m}$ breedte en I,25 m hoogte. Van twee van de vier bruinrode resten kon een afbeelding worden gegeven (A22 $a-b)$.

Ongeveer $40 \mathrm{~m}$ noordwestelijk van het vorige blok, ongeveer roo $\mathrm{m}$ zuidoostelijk van het huis van Cashero No. 24, ligt een kwartsdiorietblok van ruim $5 \mathrm{~m}$ breedte en $4 \mathrm{~m}$ hoogte, met een holte aan de zuidwestelijke zijde van $4 \mathrm{~m}$ breed en bijna $2,5 \mathrm{~m}$ hoog (A23).

In deze holte vindt men de zeer onduidelijke resten van een tiental rode tekeningen, welke door een donkergrijze laag zijn bedekt. Van deze konden er slechts twee - de in het midden van de achterwand gelegene worden afgebeeld $(a-b)$.

Aan de linkerzijde van de holte vindt men een vrij ingewikkelde tekening, waarvan de juiste vormen niet meer bij benadering zijn vast te stellen. Geheel rechts, tegen het plafond, zijn echter tamelijk duidelijke witte figuren zichtbaar, welke over de oudere rode tekeningen zijn aangebracht $(c)$. Deze witte figuren, elk ongeveer $7 \mathrm{~cm}$ groot, hebben de vorm van een konijnekop. De dubbele rij 'konijnekoppen' is $45 \mathrm{~cm}$ breed; daarboven zien we nog een grotere tekening, waarvan nog slechts enkele witte lijnen zichtbaar zijn.

\section{(A 24-26) Siribana (Fig. I8-I9, 56)}

Op de oostelijke helling van de diorietheuvel Siribana, ten noordoosten van de politiepost van Santa Cruz, vond I. TJON SIE FAT, in januari I959, twee vlak naast elkaar liggende diorietblokken met grote verweringsholten aan de zuidwestelijke zijde. In de holte van het meest zuidelijk gelegen blok zien wij een groepje pijlpunten met een ster getekend (A24 $a-f)$. Rechts in dezelfde holte zijn nog resten van een, waarschijnlijk verkleurde, lichtrode tekening $(g)$, terwijl in een kleine holte aan de linkerzijde nog iets van een tekening nauwelijks zichtbaar is.

Enkele passen westwaarts ligt een ander uitgehold blok, waarvan het plafond aan de voorzijde ten dele is afgebroken (A25). Hierin vinden wij enkele behoorlijk geconserveerde rode tekeningen. De meest opvallende geeft ons de indruk een hoofd met twee opgeheven armen voor te stellen $(d)$. Twee andere $(b-c)$ doen aan de figuren van Seroe Noka (A2I) denken.

Tussen deze rode tekeningen zien wij nog een aantal - waarschijnlijk oudere - verweerde, oranjekleurige fragmenten waarvan de vormen niet meer herkenbaar zijn.

Aan de noordoostelijke zijde van de heuvel Siribana ligt een diorietblok van ongeveer $2,50 \mathrm{~m}$ hoog en $3,60 \mathrm{~m}$ breed, met aan de westkant een uitholling van ongeveer I bij 2 meter (A26). Op drie gedeelten van de wand 
welke in historische tijd niet is afgeschilferd treffen wij de resten aan van opmerkelijk rood-gekleurde ornamenten, welke reeds door PINART (planche 2 fig. 6) werden geschetst. TJON SIE FAT fotografeerde deze tekeningen in november $195^{8}$.

$$
\text { (A 27-28) Quadirikiri (Fig. 20-23, 57-58) }
$$

In de steile, ongeveer $8 \mathrm{~m}$ hoge rand van het middenterras, ongeveer $500 \mathrm{~m}$ oostelijk van de bekende grot van Quadirikiri, bij vader Piet, bevinden zich twee kleine druipsteengrotten, in omstandigheden welke doen denken aan die van de Grot van Fontein (Ar). De oostelijke grot (A27) heeft, evenals de westelijke (A28), een omstreeks $6 \mathrm{~m}$ hoge ingang, maar wordt na enkele meters al veel lager, en vernauwt zich spoedig in grillig gevormde, nauwe gangen, die onder het kalksteenplateau wegduiken.

De oostelijke grot heeft achterin, op het nog slechts $\mathrm{I}-\mathrm{I}, 4 \mathrm{~m}$ hoge plafond, duidelijke ornamenten, in bruinachtig rood (A27 a,c), met daarnevens een aantal raadselachtige afdrukken waarvan er enkele als handafdrukken (b) te herkennen zijn (Fig. 58). De schilderingen op het plafond dichter bij de ingang, dat ruw is en erg verweerd, zijn moeilijker te begrijpen; zelfs de best bewaarde resten - door de beschouwers vlot als 'mannetjes' aangeduid $(d-e)$ - stellen ons voor raadsels.

De westelijke grot is rijker. Zowel langs de oostelijke als de westelijke zijwanden vinden wij hier, op hoogten van $1,80 \mathrm{~m}(m-o)$ zowel als omstreeks $0,90 \mathrm{~m}(k, r-s)$, een aantal resten van figuren, die ons te denken geven (b.v. $j$ en $s$ ), omdat zij ten dele als symbolen zouden kunnen worden opgevat.

Een aantal schetsen van deze rotsschilderingen welke op 12 augustus I955 werden gemaakt, konden met behulp van de foto's van TJON SiE FAT zodanig worden aangevuld, dat van de meest opvallende details thans afbeeldingen kunnen worden gegeven.

\section{(A 29) Macuarima (Fig. 24, 59)}

IvAN TJon SiE FAT's onderzoekingen gaven, zeer kort geleden, nog enkele bijzonder mooie resultaten met het vinden van de rotsschilderingen van Macuarima en Paraguaná.

Over de eerste vindplaats, welke hij op 22 maart I96I ontdekte, schrijft hij het volgende.

Niet ver van de hoofdverkeersweg door Santa Cruz, even ten Noorden van het Union-voetbalveld, ligt een opeenhoping van grote diorietblokken, op perceel No. 78 van Evaristo Geerman. In een holte van ongeveer 2,40 m breed, I,40 $\mathrm{m}$ hoog en I,50 $\mathrm{m}$ diep, aan de zuidelijke zijde van een dezer blokken, bevinden zich de volgende tekeningen:

$a$ In het midden van de achterwand, op ongeveer $74 \mathrm{~cm}$ hoogte, staat een ronde figuur van ongeveer $30,5 \mathrm{~cm}$ middellijn.

$b$ Op ongeveer $63 \mathrm{~cm}$ afstand, rechts van $a$, vindt men een ruitvormige tekening van ongeveer $15,5 \mathrm{~cm}$ lengte.

$c$ Vlak bij de grond, links, is er op een soort schrift gelijkende tekening, die een breedte beslaat van wel $1,50 \mathrm{~m}$, maar waarvan slechts het linkerdeel ter breedte van ongeveer $30 \mathrm{~cm}$ enigszins zichtbaar is.

$d$ Aan de rechterzijde, onder $b$, bevindt zich ten slotte nog een schets welke 
aan een omlijnd kruis doet denken, en welke eveneens te onduidelijk was om te worden gefotografeerd.

\section{(A 30) Paraguaná (Fig. 25-26, 60-62)}

Over de vindplaats in het buurtschap Paraguaná worden door I. TJoN SiE FAT, na zijn bezoek op 16 mei 196r, de volgende mededelingen gedaan.

Op perceel No. 7 te Paraguaná, dat toebehoort aan Nicolaas Dijkhoff, ligt - niet ver van het woonhuis - een uitgehold diorietblok dat deel uitmaakt van een trankeer. Het plafond van deze uitholling, welke naar het Westen is gekeerd, is ongeveer $1,75 \mathrm{~m}$ hoog, terwijl het overhangende gedeelte omstreeks $3,30 \mathrm{~m}$ diep is. Deze uitholling, welke de indruk geeft van een afdak, bevat de volgende tekeningen.

$a$ Een roodbruin gekleurde vogelfiguur met uitgespreide vleugels, op ongeveer $1,50 \mathrm{~m}$ hoogte, in de noordwesthoek.

$b$ Iets hoger dan $a$ staat een witte, op een leguaan gelijkende figuur, waar een roodbruine vogel, eveneens met uitgespreide vleugels, gedeeltelijk overheen is geschilderd.

$c$ Tegen het plafond: witte concentrische cirkels; in de ietwat verbleekte meest rechtse figuur, is een dierenfiguur in rood zichtbaar; iets meer naar rechts zijn er verschillende roodbruine tekeningen naast en over elkaar heen geschilderd, zodat de vormen hiervan niet meer te herkennen zijn. $d$ Eveneens tegen het plafond, in de zuidwesthoek, een roodbruin gekleurde 'zon', met vlak daarbij enkele parallele, gebogen, witte lijnen. $e$ Op de achterwand, over een breedte van ongeveer $72 \mathrm{~cm}$, witte en roodbruine tekeningen; de meest linkse en de meest rechtse rode tekening van deze groep doen aan schildpadden denken.

$f$ Tegen het plafond, meer achterin dan $d$, witte concentrische cirkels over niet meer te herkennen rode tekeningen, een vlak bestrijkend van ongeveer $66 \mathrm{~cm}$ lengte.

Deze tekeningen vertonen veel overeenkomst met die van Ajó en Arikok.

\section{BESCHRIJVING VAN VINDPLAATSEN OP CURAÇAO}

$$
\text { (C } 4 \text { ) Hato (Fig. 27-28, 63-65) }
$$

Tijdens een haastig bezoek aan het abri van Hato, op 7 augustus I955, konden door mij nog enkele aanvullende waarnemingen aan de zich daar bevindende reliëfs worden gedaan (vgl. I, p. 25, fig. I8-2I).

Het bleek, dat deze niet zijn uitgehouwen in (harde) kalksteen maar in (zachte) verweerde druipsteen. De gehele westelijke wand van deze abri - waarvóór Ringma indianenskeletten had opgegraven - ongeveer $9 \mathrm{~m}$ lang, en $2 \frac{1}{2}-3 \mathrm{~m}$ hoog, draagt op vele plaatsen sporen van bewerking. Hier en daar vindt men ook nog onduidelijke roodbruine krabbels, waarvan niet veel te maken is. Waarschijnlijk is deze druipsteen na de bewerking nog veel meer gaan verweren, waardoor de meeste reliëfs thans ruw en onduidelijk zijn (vgl. Fig. 63), met randen waarvan men met de vingers stukjes kan afbreken.

De petroglyphen zijn over het algemeen zeer onduidelijk; zij konden pas goed worden gefotografeerd nadat zij met krijt zichtbaar waren ge- 
maakt (Fig. 64-65). Het 'gelaat met hoofdtooi' bleef een niet geheel overtuigende uitbeelding: de neus en mond zijn onduidelijk en berusten voor een groot deel op fantasie; de ogen zijn gaten (vooral het linkeroog is groot en diep) welke een niet geheel kunstmatige indruk maken. Het lijkt niet onmogelijk, dat men het gelaat om deze twee natuurlijke (oog-) gaten heeft gemodelleerd.

De driehoekige omtrek van het gezicht is diep ingegrift. Dergelijke driehoekige omtrekken vindt men terug links boven en rechts van het gelaat, en (zeer onduidelijk) ook nog enkele keren op andere plaatsen, zonder dat hierin gezichten zijn te herkennen.

$$
\text { (C II-I2) Santa Martha (Fig. 30-34, 66) }
$$

In de opgeheven brandingsnis van het middenterras, ten Westen van de ingang van de Santa Martha baai, werd door G. H. BARNEVELD, in juli 1953, de eerste rotstekening aan de 'zuidkust' ontdekt (als wij de vindplaats aan de noordzijde van de Tafelberg van Santa Barbara niet medetellen). Bij een nader onderzoek van dezelfde brandingsnis aan de oostzijde van de baai, vond J. G. DE JoNG, in augustus 1953, nog een serie ornamenten - waarmede het dozijn vindplaatsen op Curaçao was volgemaakt.

De eerste vindplaats $\left(\mathrm{C}_{1} \mathrm{I}\right.$ ) werd mij op 13 februari 1955 door P. A. VAN DER WERF getoond. Hij ligt omstreeks 80 meter ten Westen van de monding van de baai, 200 meter van de zee verwijderd, op ongeveer 20 meter hoogte. De kalksteen van deze Oost-West verlopende nis - waarvan de vorm in Fig. 30 is weergegeven - is ruw en leent zich niet erg goed voor beschilderen. De duidelijkste figuur $(b)$ is donkerbruin. Ruim I meter oostelijk hiervan staat een veel vagere, hiermede wellicht vergelijkbare voorstelling in het lichtbruin $(a)$. Overal in de omtrek vinden wij onregelmatige vlekken van dezelfde lichtbruine kleur, welke ouder lijken te zijn dan het donkerbruin van de duidelijke figuur en van nog enkele vegen in de omgeving daarvan.

In de zachte bodem vóór de drempel werden slechts enkele schelpen en potscherven gevonden.

De ornamentale tekeningen in de Noordoost-Zuidwest verlopende brandingsnis aan de oostzijde van de Baai, ongeveer 70 meter van de oever, werden mij op 16 augustus 1955 door mevrouw A. DE JoNG-SNETHLAGE aangewezen $\left(\mathrm{C}_{12}\right)$. Het zijn ingewikkelde tekeningen, op het plafond van een niet meer dan I meter hoog abri, die niet overal even duidelijk zijn. Het zijn resten van een veel uitgebreidere, roodbruine beschildering (vgl. Fig. 34).

$$
\text { (C I3) St. Jan (fig. 35-36) }
$$

Nadat er bij de Boca van St. Martha rotstekeningen waren gevonden, besloot de Heer J. G. DE Jong ook nog andere delen van de Curaçaose zuid-westkust aan een nauwkeurig onderzoek te onderwerpen. Het meest in aanmerking hiervoor kwam de omgeving van de Boca van St. Jan, welke een met de kust van St. Martha vergelijkbaar landschap vertoonde. En inderdaad werd door hem op deze plaats, in een opgeheven brandingsnis aan de westzijde van de puinwal welke de binnenbaai van St. 
Jan (sinds de orkaan van 2 november 1932) van de zee afsluit, op I9 april I959, een vrij groot aantal tekeningen gevonden. Begin mei volgde een meer nauwkeurige bestudering, waaraan de hieronder vermelde gegevens zijn ontleend.

De plaats waar de rotstekeningen voorkomen bevindt zich ro meter boven de zeespiegel en is langs een pad over de plateaurand gemakkelijk te bereiken. De abri loopt vrijwel evenwijdig aan de kustlijn en heeft een begaanbare lengte van 36 meter, met een plafond dat aan zeezijde hoog genoeg is om rechtop te kunnen lopen. Dan volgt nog een rotsrichel van 8 meter lengte, waarna de nis tenslotte geheel verdwijnt en de rotswand steil naar beneden gaat.

De abri geeft goede beschutting en biedt een prachtig uitzicht over de Boca en de Caraïbische Zee; ook strategisch is het stellig een sterk punt.

De eerste 35 meter - van Oost naar West gerekend - zijn op de situatie ${ }^{-}$ schets (Fig. 36) weergegeven.

De tekeningen zijn resten van figuren, die uit een vrij willekeurig samenstelsel van rechte en gebogen lijnen lijken te bestaan. $\mathrm{Zij}$ zijn evenals alle andere van Curaçao bekende tekeningen - bruinachtig rood van kleur, doch vertonen verder hiermede geen duidelijke overeenstemming.

De 56 tekeningen welke nog met enige duidelijkheid zijn te onderkennen vindt men in de eerste 30 meter van de abri. Vage resten van andere schilderingen doen vermoeden dat de meeste fragmenten zijn van grotere figuren welke een groot deel van het plafond hebben bedekt. Van verschillende delen werden door de Heer J. G. DE JoNG de schetsen gemaakt, welke op Fig. 35 staan weergegeven.

Over de eerste 4 meter bevinden zich op het plafond slechts een viertal onduidelijke resten. Tussen de druipsteenpilaartjes zien wij, op de achterwand van de abri, echter nog vrij duidelijk een overblijfsel van een tekening $(a)$, en ook nog een van een veel grotere figuur $(b)$. Ook op de voorwand,boven de eerste pilaar staan nog twee duidelijke resten. Tussen de 6 en de 8 meter staan dan nog een 6 -tal onduidelijke restanten op het plafond.

Vlak voor de Io meter staan op de zoldering een I $_{5}$-tal, soms vrij duidelijke, nogal ingewikkelde figuren die kennelijk tot één complex behoord hebben, en die pas goed te zien zijn nadat een dunne verweringslaag is weggekrabd $(c)$. Tussen de ro en de $\mathbf{I}_{4}$ meter vinden wij op het plafond, vóór de richel, 5 onduidelijke resten en I duidelijke $(d)$ tekening.

Over de volgende zes meter is het plafond vrij ruw. Eerst krijgen wij hierop nog 4 resten van tekeningen, en op het laatste deel nog $\mathrm{I}$ onduidelijk restant. Tussen de $2 \mathrm{I}$ en 23 meter zien wij nog twee gecompliceerde figuren en één meer eenvoudige tekening $(e)$. Vervolgens zijn er nog enkele onduidelijke vegen en dan nog een zestal duidelijker waarneembare fragmenten in en rondom een holte in de achterwand, plus enige vegen op het plafond.

Bij 29 meter staat nog een vrij duidelijke tekening $(f)$. Verder zijn er geen waarneembare figuren meer, ofschoon het plafond hier vlak is.

Tijdens de inventarisatie van de tekeningen werden de met zand gevulde holten in de abri en de ruimte achter de richel uitgegraven. De resultaten waren echter slechts enkele Strombus-fragmenten, welke als krabbers gediend zouden kunnen hebben, zoals ook langs het pad naar de Boca gevonden werden. 


\section{(C I4) Koraal Tabak (Fig. 37-38,67)}

Meer dan tien jaar nadat A. D. Ringma in de abri van Hato de eerste ingekraste tekeningen had ontdekt, viel het oog van SoPHIA DE JoNGvAN HeUZEN op een verweerde stalagmiet, die met ogen, neus en mond was begiftigd. Dit was op 15 februari 1960 , toen een grot in het kalkplateau van de Seroe Kibra Pica, op de Plantage Koraal Tabak, op indianentekeningen werd onderzocht. Toen een nader onderzoek twijfel aan de oudheid van dit 'beeldhouwwerkje' had weggenomen, werd het stuk door J. G. DE JoNG, de leider van de kleine excursie (waaraan behalve de familie DE Jong ook de archeologen H. R. van HeEkeren en C. J. Du RY deelnamen) 'Joris Tabak' gedoopt.

De grot is omstreeks $50 \mathrm{~m}$ breed en $16 \mathrm{~m}$ diep (Fig. 37); zij ligt in een sterk verkarst kalksteenterras dat met vele grotten en spleten is doortrokken. Het dak is zeer dun en zit vol spleten en gaten. Actieve druipsteen is bijna niet te vinden.

De mond van Joris Tabak is ongeveer $7 \mathrm{~mm}$ diep; de neus staat wat naar links en lijkt, zeer modern, en reliëf te zijn uitgewerkt. De ogen zijn z.g. koffieboon-ogen. De kaaklijn is vrij ruw uitgehakt en lijkt sterk verweerd. Druipsteen-groeven en golfjes geven de indruk van een gerimpeld voorhoofd, een behaard gezicht en een indrukwekkende baard.

In de grot waren geen aanwijzingen van vroegere bewoning te vinden. Voor de ingang werden schelpresten gevonden, maar deze komen in de omgeving zoveel voor, dat dit op zichzelf niets zegt.

\section{NIEUWE LITERATUUR}

\section{NEW REFERENCES}

Publicaties gemerkt met een ${ }^{*}$ bevatten geen gegevens over rotstekeningen.

Publications marked with an ${ }^{*}$ do not contain data on petrographs.

In the text, reference to the first paper of this series is made by a simple I, to the second paper by a II.

1953 WagenaAR Hummelinck, P.: Rotstekeningen van Curaçao, Aruba en Bonaire. W. I. Gids 34, 1953, p. 173-209, 36 figs., ro of which on 6 plates excl. (Summary, p. 207-209, expl. of figures also in English). - At the same time issued as a separate booklet by the Natural Science Study Group of the Netherlands Antilles (Uitgaven Natuurwetenschappelijke Werkgroep Nederlandse Antillen 2). Reference to this publication has been made by a simple: I.

1957 WagenaAr Hummelinck, P.: Rotstekeningen van Curaçao, Aruba en Bonaire, II. W. I. Gids 37, 1957, p. 93-126, 4I + 8 figs., 30 of which on 20 plates excl. (Summary, p. II9-I2I, expl. of figures 
also in English). - (Uitg. Werkgroep N.A. 6). - Reference to this publication has been made by a simple: II.

1958 Prenda Antiyano. Verjaardagskalender, Kalénder di cumpleaños. Uitg. Werkgroep N.A. 8, 26 pp. ill. - Including 12 pages with drawings of petrographs by $\mathrm{P}$. WAGENAAR HUMMELINCK, from Aruba (A $4 b-d ; 7 e-g, i ; 5 i-j, w, x$; I 3-6, 9, $17,20,29,27,45-48$; I $23 ;$ I 19,7$)$, Curaçao (C 1o $n ; 6 ; 7 f ; 12 b$, ro $m$ ), and Bonaire (B3 and 6).

*i959 WagenaAr Hummelinck, P.: Indiaanse skeletvondsten op Aruba en Curaçao. W. I. Gids 39, 1959, p. 77-94, 3 figs., 5 pls. excl.

* TAcoma, J.: Indian skeletal remains from Aruba. W. I. Gids 39, 1959, p. 95-112, 7 figs., 3 pls. excl.

Both articles in: Studies on the physical anthropology of the Netherlands Antilles: I-II. Uitg. Werkgroep N.A. 9.

1959 Feriz, H.: Zwischen Peru und Mexico (2 vols.). Meded. Kon. Inst. Tropen Amsterdam 134 (Afd. Anthrop. 63). - Aruba und Bonaire: p. 98-136; see this paper.

1959 Coomans, H. E.: Nieuwe rotstekeningen van Indianen op Curaçao ... ontdekt door J. G. de Jong. Amigoe di Curaçao 25. IV. 1959, p. 4. - Referring to $\mathrm{C}_{13}$.

* 1960 Du RY, C. J.: Notes on the pottery of Aruba, Curaçao and Bonaire. Nieuwe $W$. I. Gids 40, p. 81-102, 2 figs., pl. I - XXIIa excl.

* HeEkeren, H. R. van: A survey of the non-ceramic artifacts of Aruba, Curaçao and Bonaire. N. W. I. G. 40, p. 103-112, pl. XXIIb - XXVI excl.

Both articles in: Studies on the archaeology of the Netherlands Antilles: I-II. Uitg. Werkgroep N.A. Io.

I96I Hartog, JоH.: Curacao, van kolonie tot autonomie (2 vols.). D. J. de Wit, Aruba. - 'Indianentekeningen': p. 19-23, with drawings of petrographs $\mathrm{C}_{1} a, \mathrm{C}_{4} a, \mathrm{C}_{7}, \mathrm{C}$ ron, $\mathrm{C}_{12} b$, and of petroglyphs $\mathrm{C}_{4} \alpha$ and $\gamma$. Same figures as reproduced in 'Rotstekeningen' I and III. 


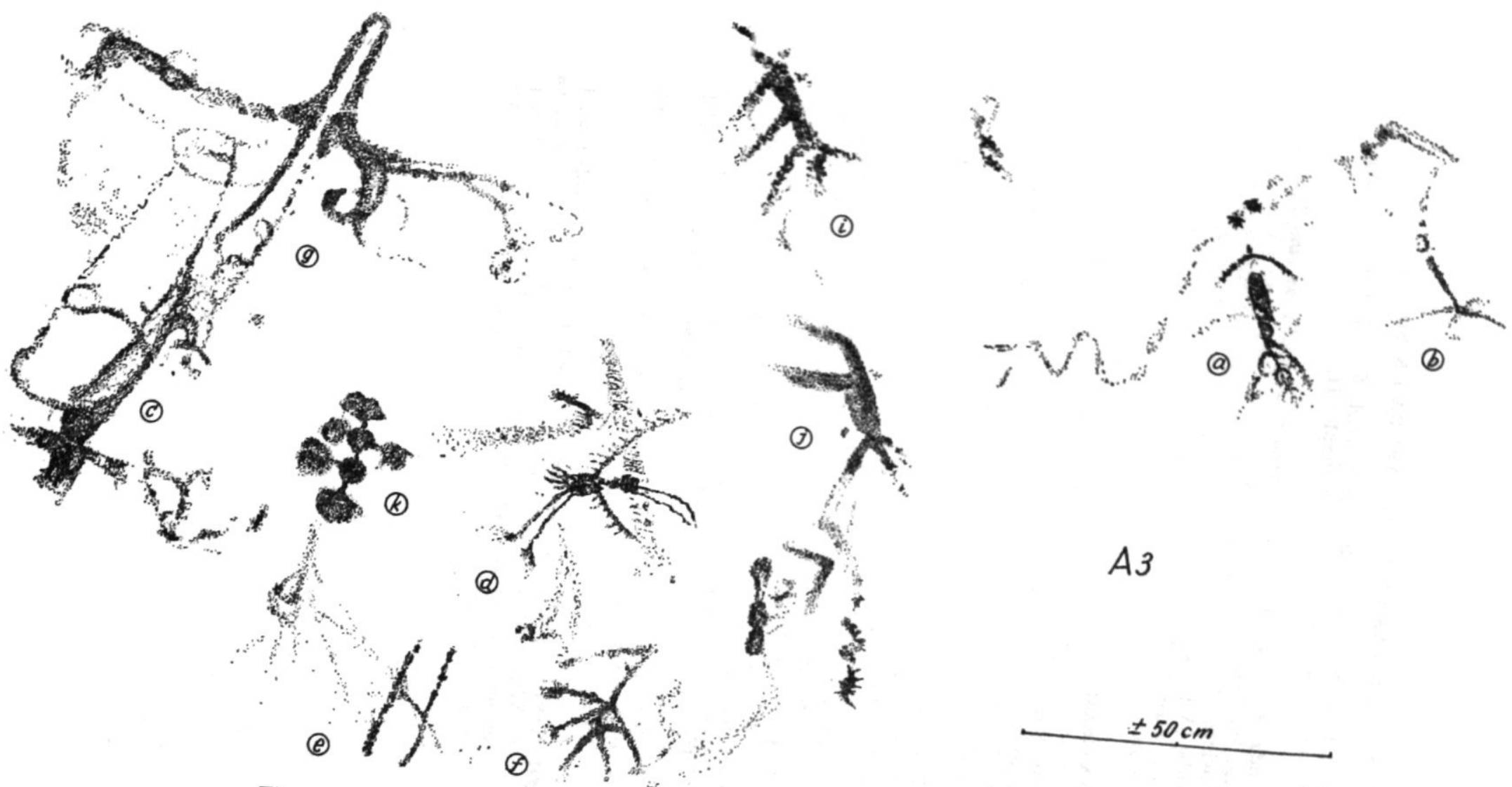

Alle tekeningen van Arubaanse

All pen and ink drawings of Aruba

Figs. 5-22, duceerd (Fig. 5-22, 24-26) zijo-31).

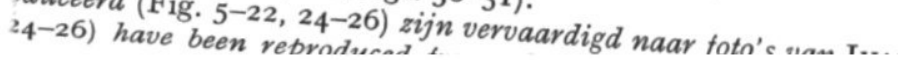



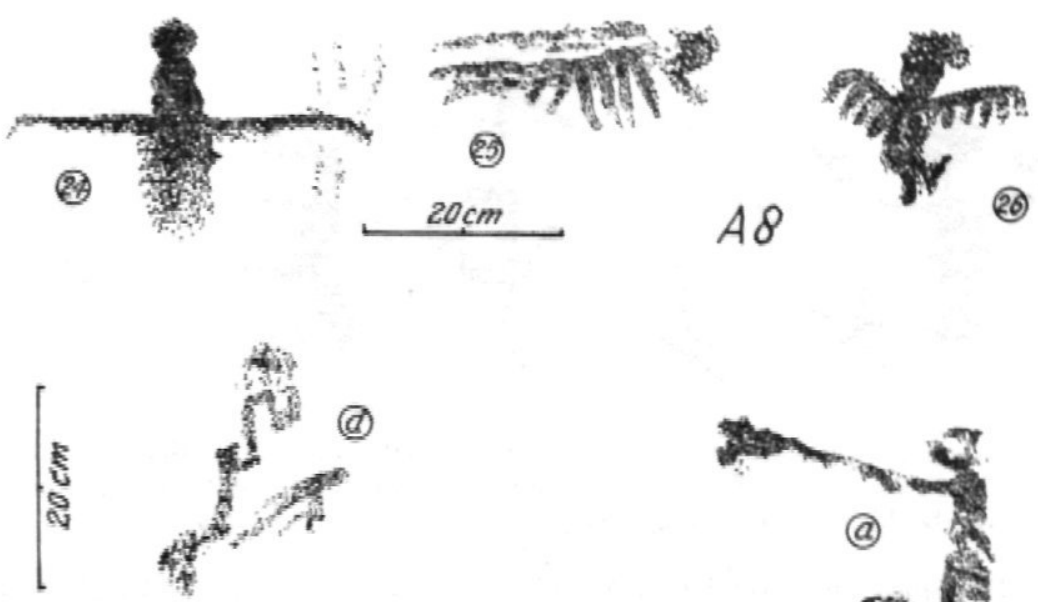

(6)
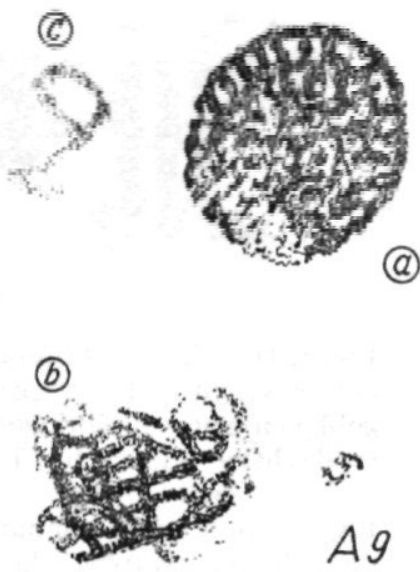

(a)

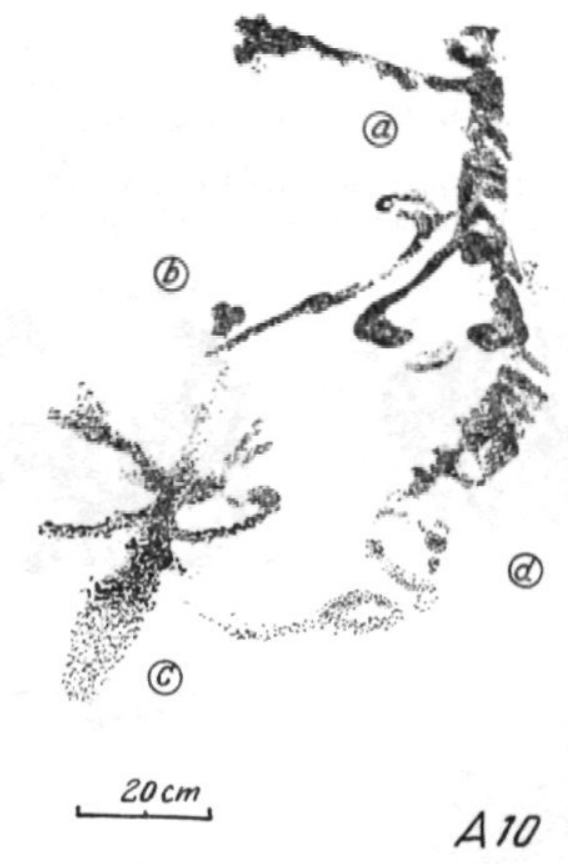

Fig. 6. Resten van rotstekeningen uit een kleine, diepe uitholling van een diorietblok van Arikok, Aruba (A8), welke reeds door PINART in 189o, werden afgebeeld (vgl. II, planche 2 fig. 4) werden afgebeeld. - Een groepje tekeningen van een ander rotsblok van Arikok (A9), grotendeels reeds afgebeeld in II, fig. I9 (vgl. Fig. 46). - Resten van een beschildering bij Arikok (Aro) welke door afschilfering van het diorietgesteente zeer onduidelijk is geworden.

Fig. 6. Remains of petrographs, on diorite rock at Arikok (A8), already reproduced by PINART (I89o; cf. II, planche 2 fig. 4). - Two groups of rock drawings at Arikok: A9, previously dealt with (cf. II, fig. 19), and at a new site, Aro, damaged by weathering (cf. Fig. 46). 


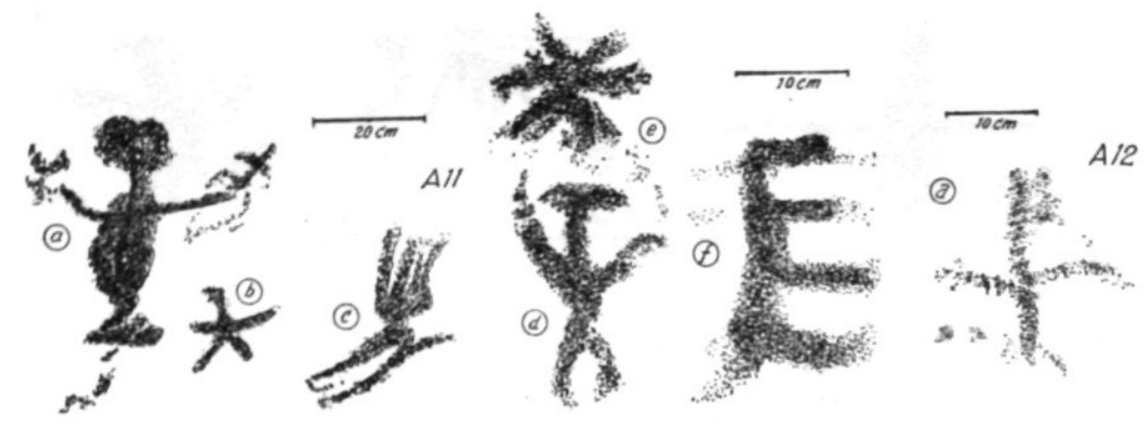

Fig. 7. Overblijfselen van roodbruine rotstekeningen uit een ander diorietblok van Arikok, Aruba (A II), welke ook reeds door Pinart (I89o; vgl. II, planche 6 fig. 9) werden afgebeeld. - Een vaag restant uit een ander rotsblok van Arikok (A I2; vgl. fig. 47).

Fig. 7. Drawings on a boulder at Arikok (A II), already sketched by PINART (I890; cf. II, planche 6 fig. 9), and a poor remnant from another boulder (A 12).


(C)

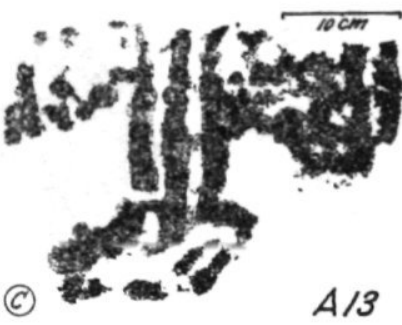

Fig. 8. Door het afschilferen van het gesteente slecht bewaard gebleven rotsschilderingen van roodachtige kleur, bij Babijn, Aruba (A 13).

Fig. 8. Indistinct remnants of reddish petrographs, damaged by weathering, in a hollowed boulder at Babijn (A I3).?

Fig. 9. De rotstekeningen welke nog te zien zijn op het in Fig. 49 afgebeelde diorietblok bij Babijn, Aruba (A I4; vgl. Fig. $4^{8}$ ). Fig. 9. Petrographs as still to be observed at Babijn (A $\mathbf{r}_{4}$; cf. Figs. 48-49). 

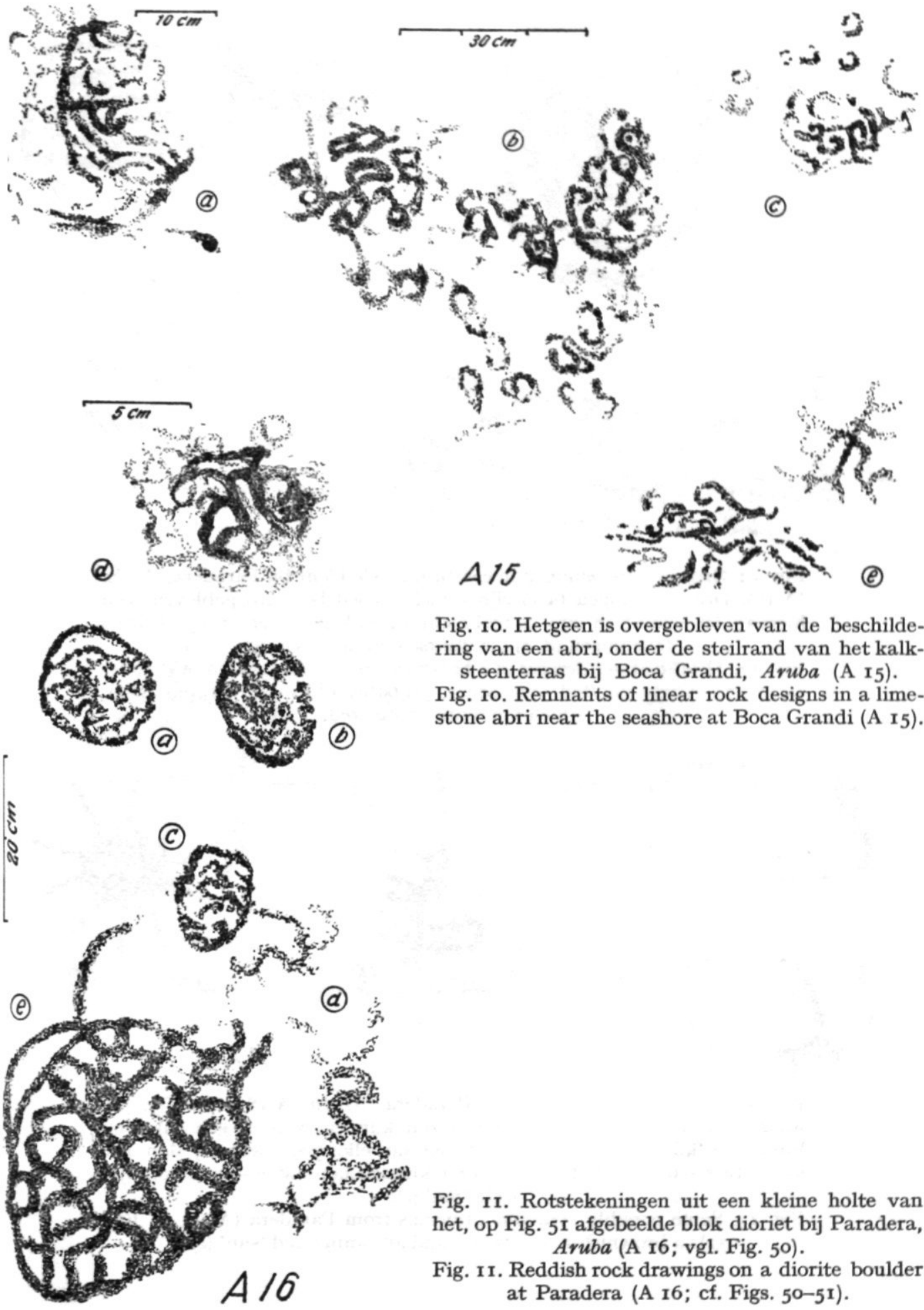

Fig. ro. Hetgeen is overgebleven van de beschildering van een abri, onder de steilrand van het kalksteenterras bij Boca Grandi, Aruba (A r5).

Fig. 10. Remnants of linear rock designs in a limestone abri near the seashore at Boca Grandi (A 15 ).

Fig. II. Rotstekeningen uit een kleine holte van het, op Fig. 5I afgebeelde blok dioriet bij Paradera, Aruba (A 16; vgl. Fig. 50).

Fig. II. Reddish rock drawings on a diorite boulder at Paradera (A 16; cf. Figs. 50-51). 
(a)
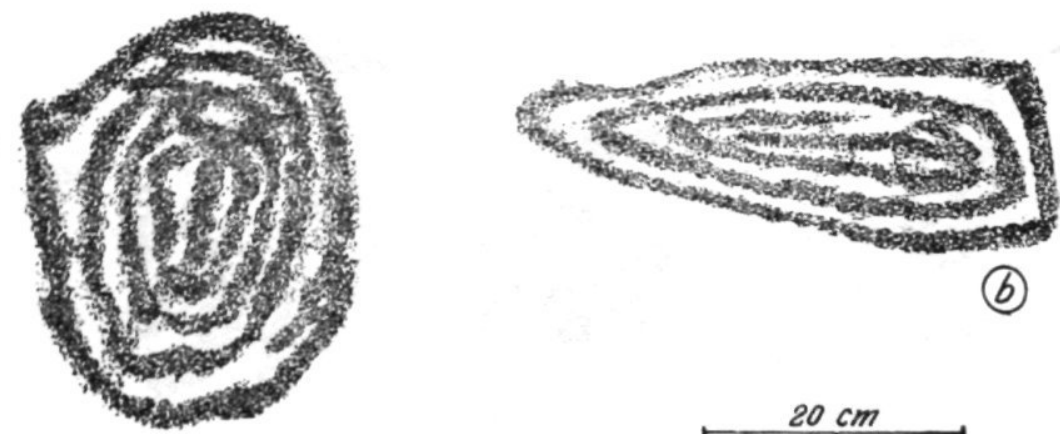

(d)

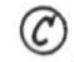

(c)

manm

(e)

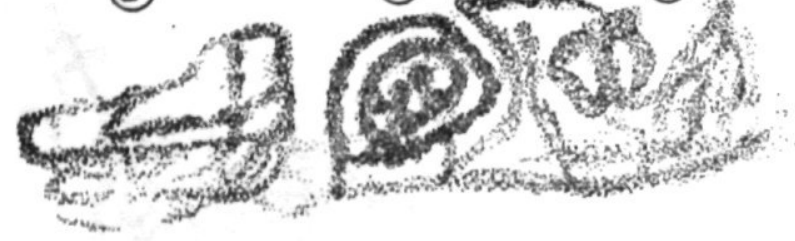

$A / 7$

Fig. 12. Groep rotstekeningen in een bruin-rode kleur bij Paradera, Aruba

(A 17 ). Drie tekeningen ( $a-c)$ zijn tamelijk goed bewaard gebleven; een

hiervan (c) schijnt te zijn aangebracht op enkele, meer oranjekleurige tekeningen (d-e) die waarschijnlijk ouder zijn.

Fig. I 2. Three distinct designs of a brownish-red colour $(a-c)$ from Paradera (A I7), partly painted over other, probably older petrographs $(d-e)$, which are more orange red.
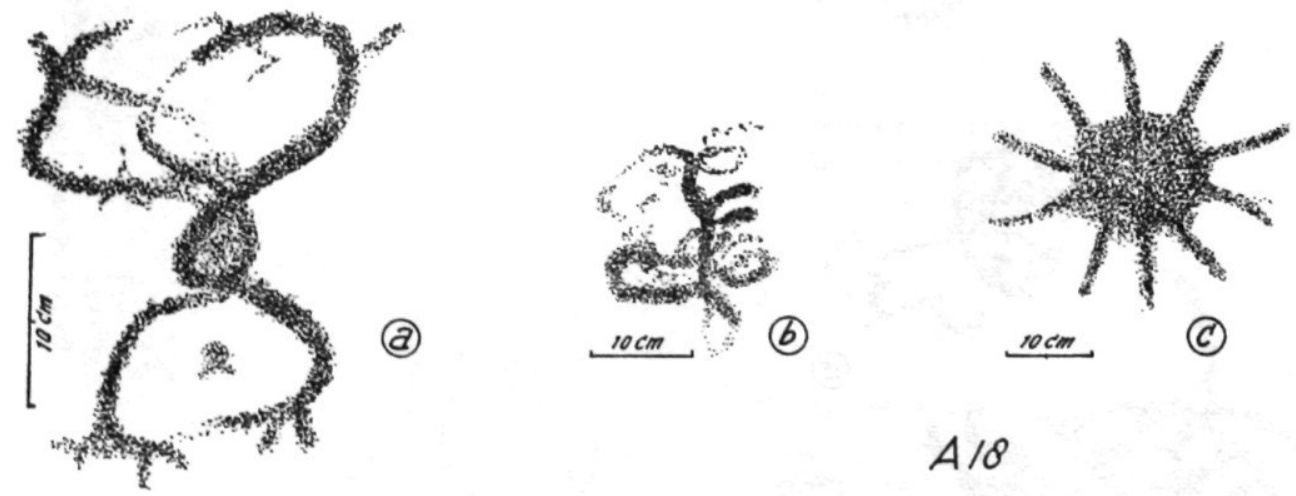

Fig. 13. Enkele tekeningen over Paradera, Aruba (A r8; vgl. Fig. 52) waaraan een symbolische betekenis zou kunnen worden gehecht: een bruinrode 'kikker' $(a)$ - met drie tenen aan elke poot, waarbij dan het vlekje tussen de 'voorpoten' de kop zou kunnen aanduiden - en een oranjerode 'zon' (c).

Fig. 13. Some possibly symbolic drawings from Paradera (A 18; cf. Fig. $52)$ : a brownish-red 'frog' $(a)$ and an orange-red 'sun' (c). 

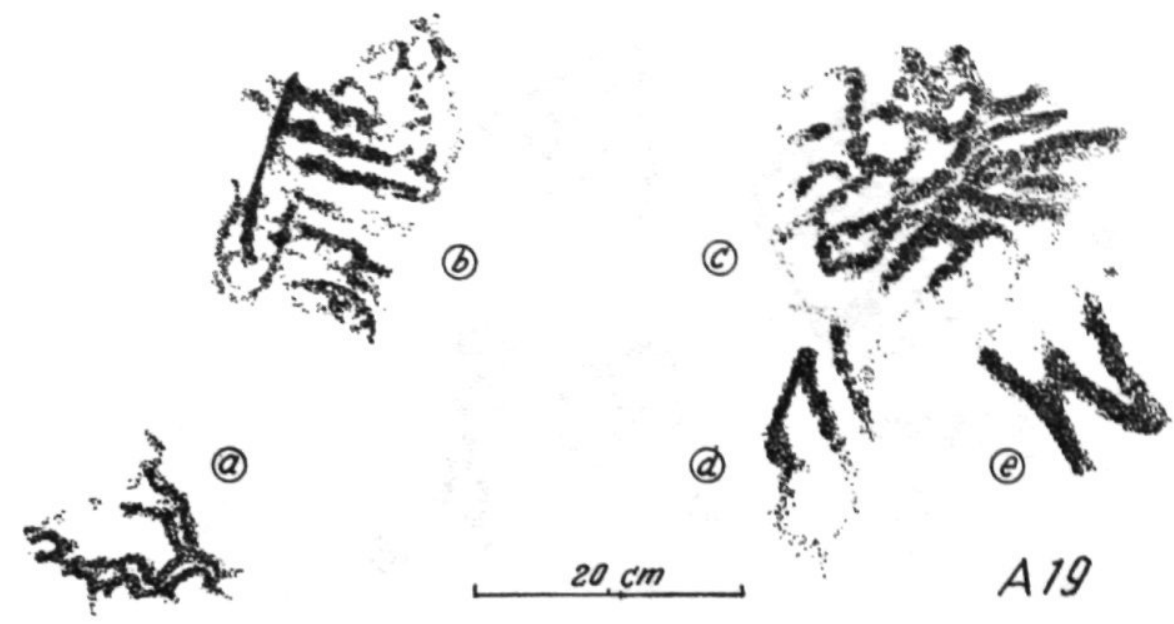

Fig. 14. Nog enkele overblijfselen van rotstekeningen van Paradera, Aruba (A 19).

Fig. I4. A few more remains of rock drawings from Paradera (A 19).
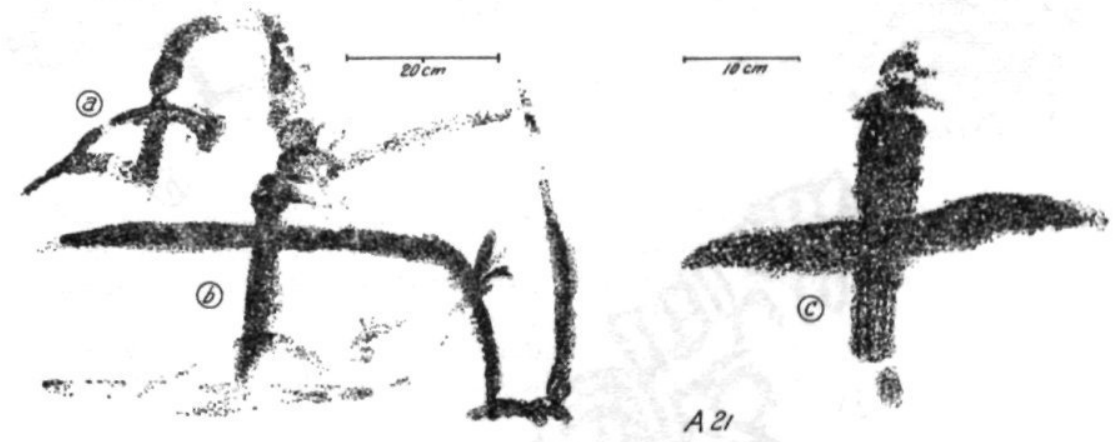

Fig. 15. Onduidelijke schilderingen op een rotsblok bij het 'urnenveld' van Santa Cruz, bij de Seroe Noka, Aruba (A2 I).

Fig. 15. Reddish paintings, as traced from a piece of diorite at Seroe Noka (A2I). 


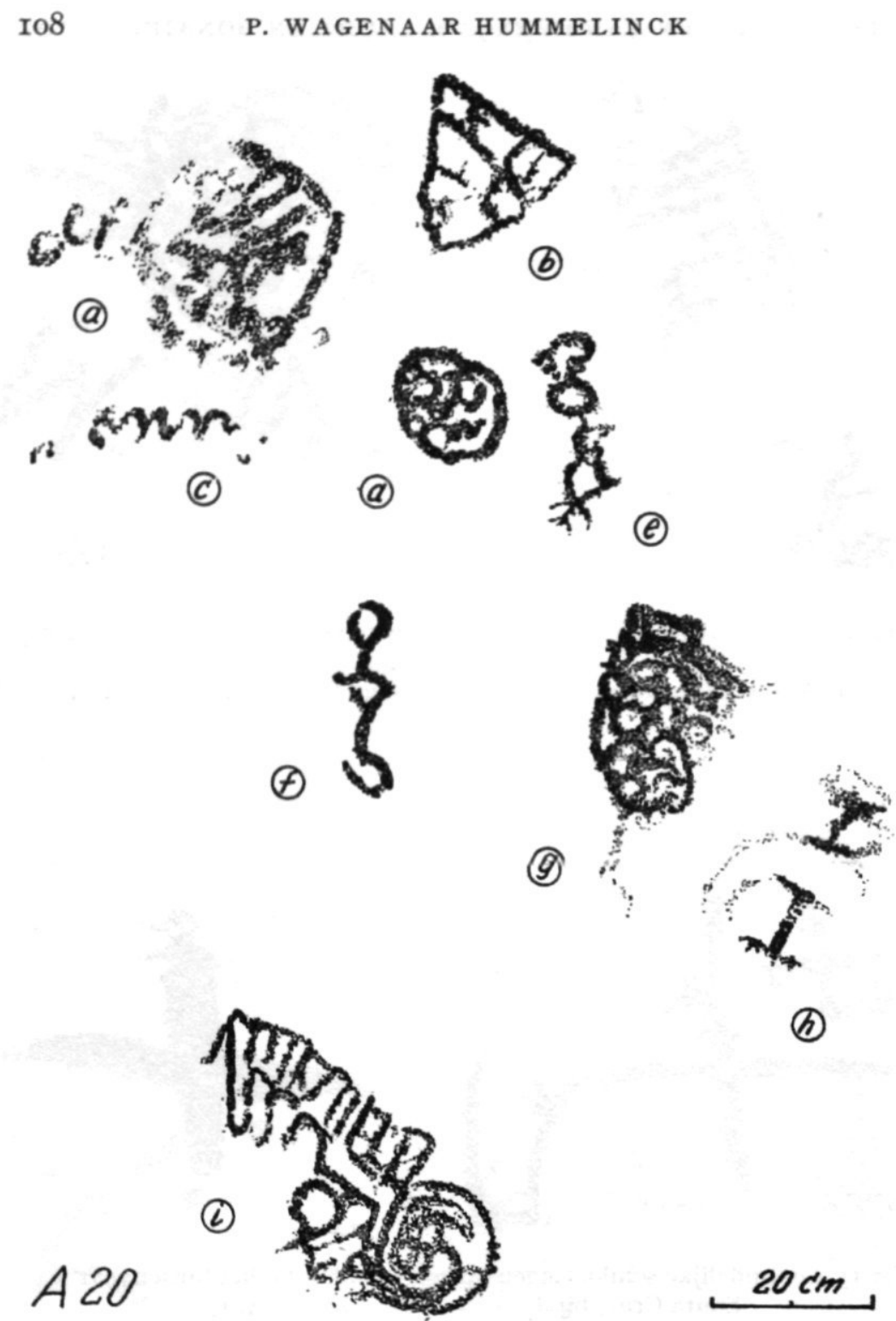

Fig. 16. Een mooi groepje tekeningen uit de holte van een diorietblok bij Casibari, Aruba (A 20; vgl. Fig. 53-54).

Fig. 16. A fine collection of drawings from a diorite boulder near Casibari (A 20; cf. Figs. 43-54). 


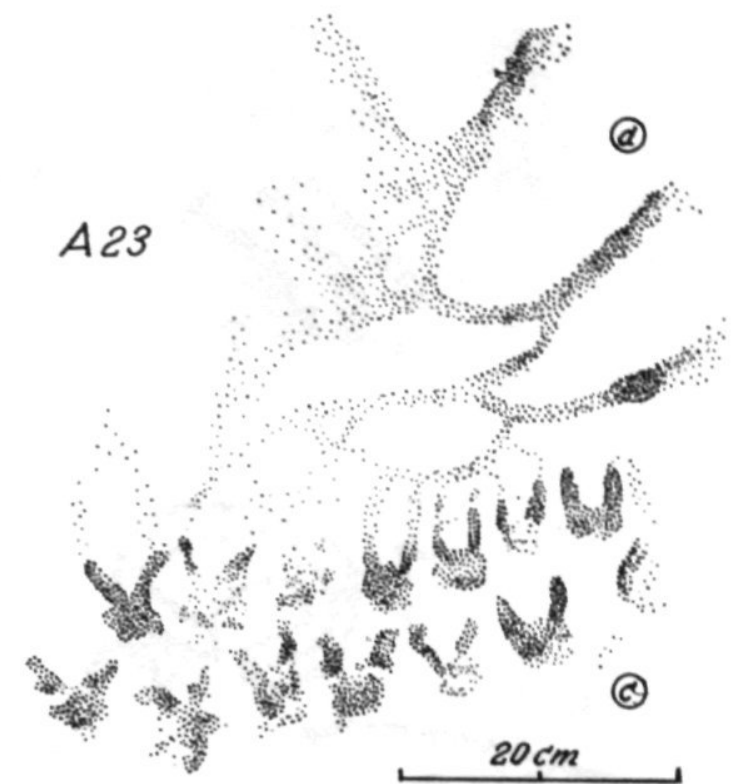

(b)
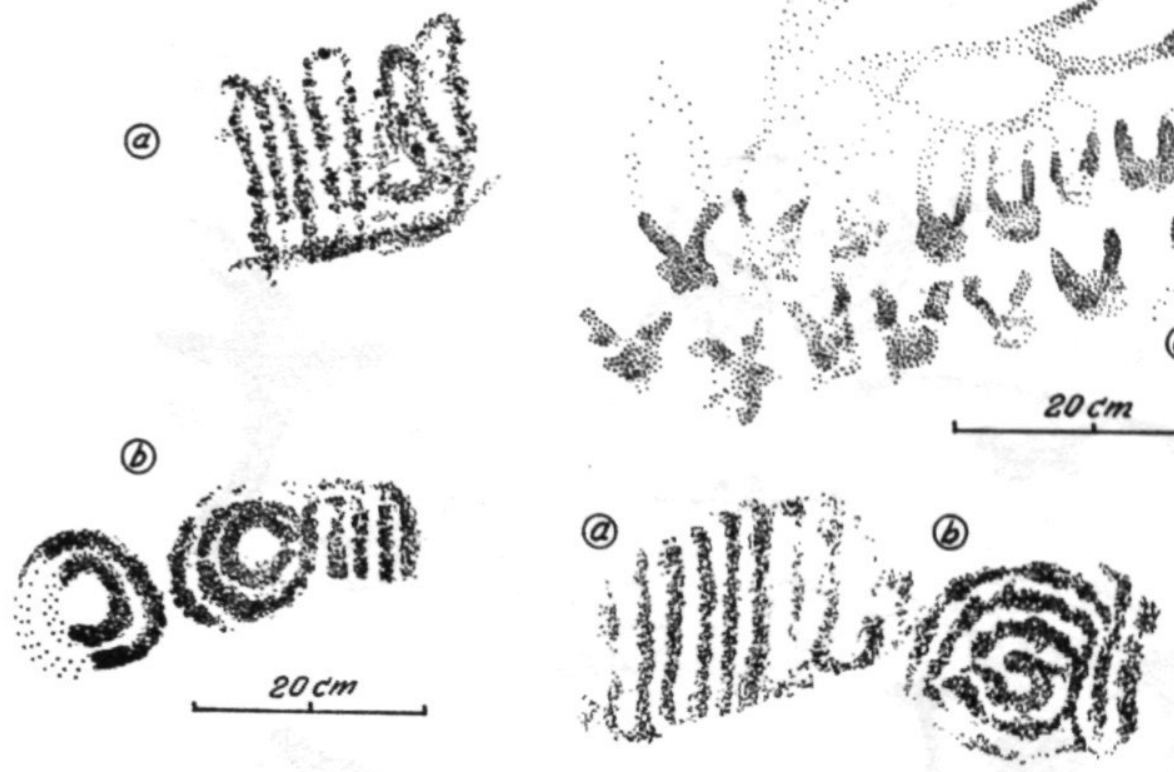

Fig. 17. Rotsschilderingen bij Shabururi, Aruba (A 22-23). De dubbele rij 'konijnekopjes' (23c) en de grotere tekening waarmede deze samenhangen $(d)$ zijn niet met een rode maar met een witte kleurstof aangebracht (vgl. Fig. 55).

Fig. 17. Rock paintings at Shabururi (A 22-23), including a series of 'rabbit heads' which are not brownish-red as usual, but executed in white paint (cf. Fig. 55). 


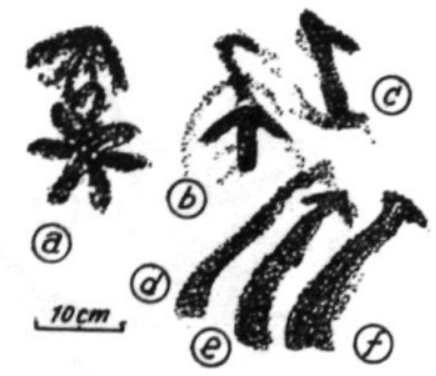

A24
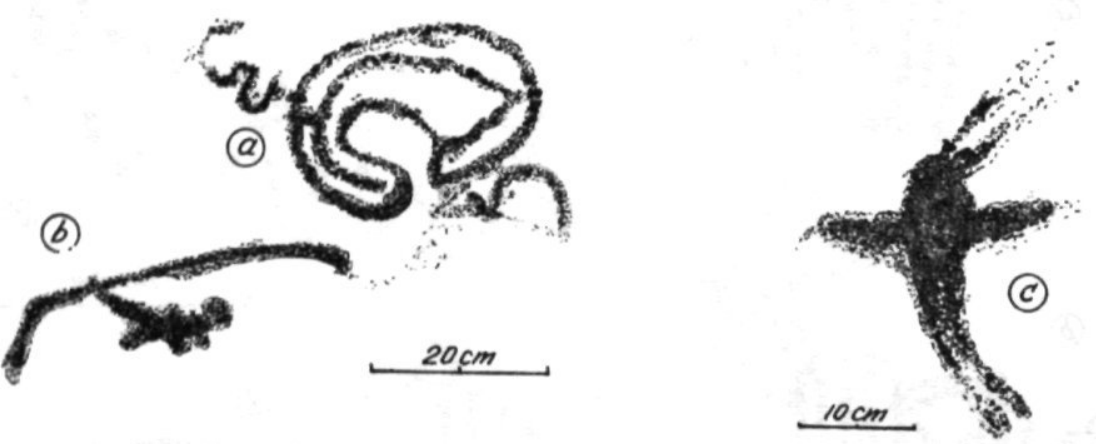

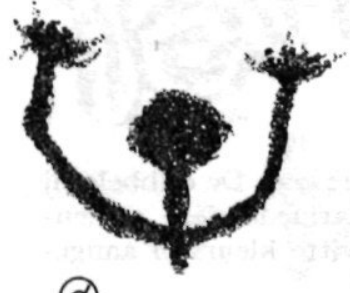

(d)

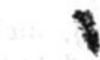

(e)

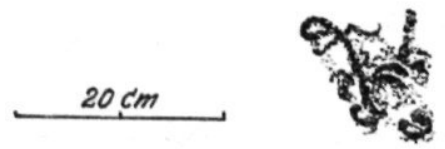

\section{5}

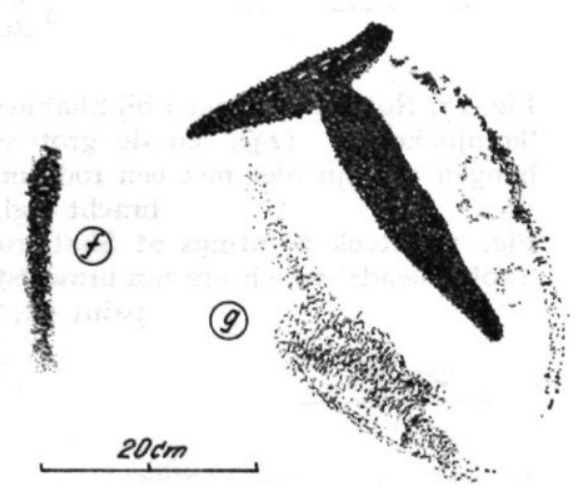

Fig. 18. Twee series rotstekeningen van Siribana, Aruba (A 24-25), met een duidelijke ster $(24 a)$ en pijlpunten $(24 b-f)$, en een figuur die ons de indruk geeft een hoofd met opgeheven armen voor te stellen $\left(25^{d}\right)$.

Fig. 18. Two series of rock drawings from Siribana (A 24-25), with a few striking figures $(24 a-f, 25 d)$. 
(a)

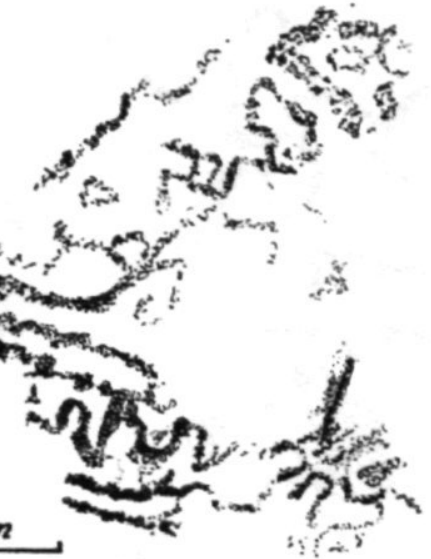

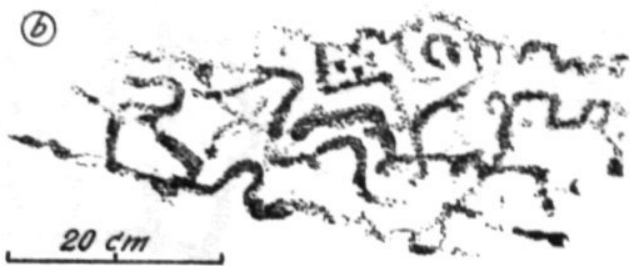

\section{A26}

(C)

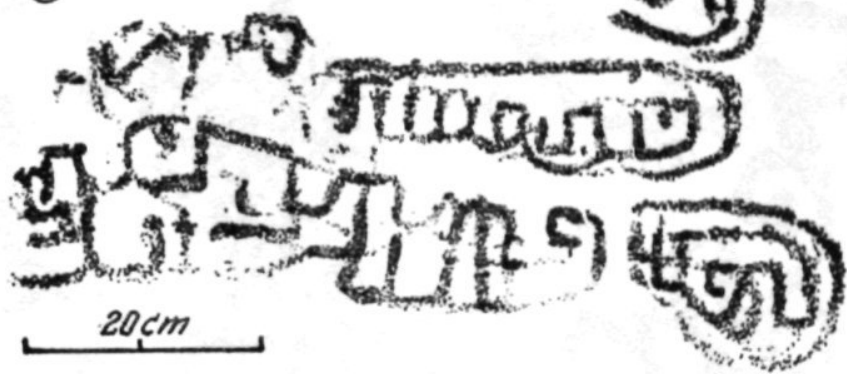

Fig. 19. Ornamentale tekeningen van Siribana, Aruba (A 26), waaronder wij er aantreffen, die reeds door PINART in 1890 werden afgebeeld (II, planche 2 fig. 6; vgl. Fig. 56).

Fig. 19. Ornamental rock drawings from Siribana (A 26), including those sketched by Pinart in 1890 (II, planche 2 fig. 6 ; cf. Fig. 56). 
II2

P. WAGENAAR HUMMELINCK


Fig. 20. Resten van tekeningen op een, ten dele zeer ruw en verweerd plafond van een kleine druipsteengrot, beoosten de Grot van Quadirikiri, Aruba (A 27; vgl. Fig. 23, 58). Van de verscheidene handafdrukken welke achterin deze abris voorkomen is er slechts én (van een linkerhand) getekend.

Fig. 20. Remains of brownish-red drawings on the ceiling of a small limestone cave, to the east of the much larger cave of Quadirikiri (A 27, cf. Figs. 23, 58), including one print of a left hand.

Downloaded from Brill.com๑4/26/2023 10:47: ๑९AM

via free access 


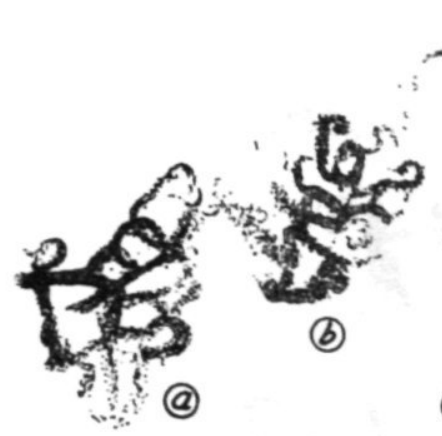

(C)
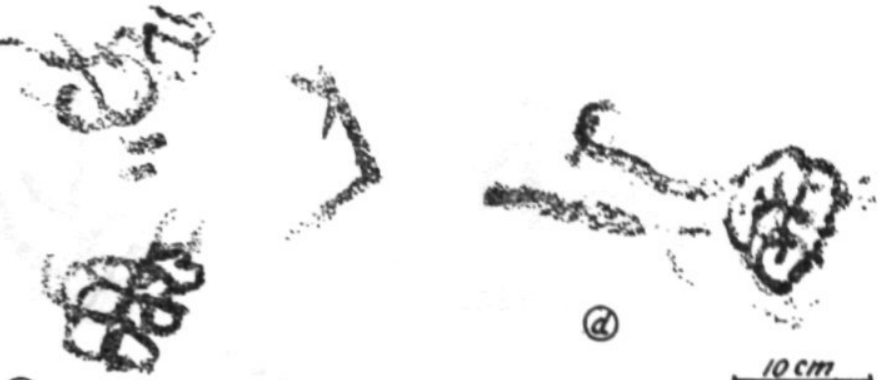

(d)

$10 \mathrm{~cm}$

$10 \mathrm{~cm}$

428

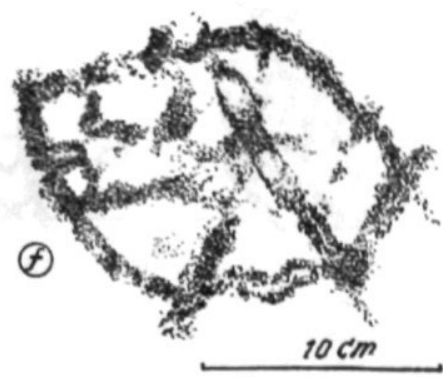

$10 \mathrm{~cm}$
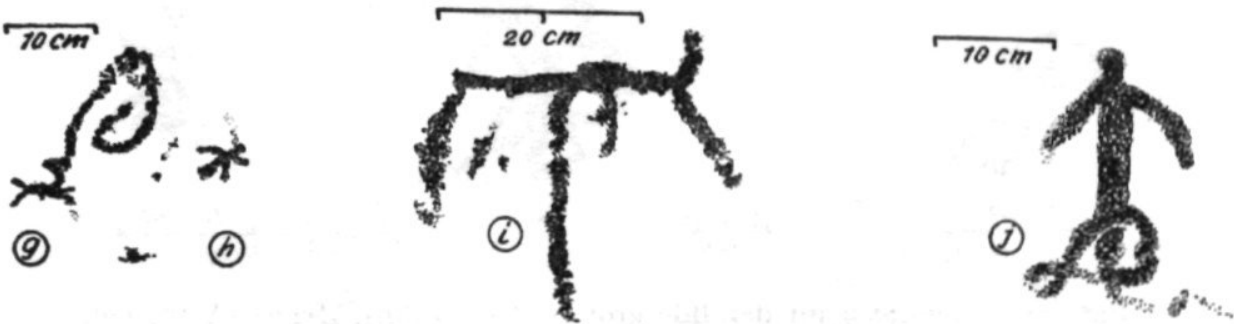

Fig. 2r. Tekeningen in het westelijke deel van dezelfde abri bij Quadirikiri, Aruba (A 28; vgl. Fig. 23, 57).

Fig. 21. Petrographs from the western part of the same limestone abri near Quadirikiri (A"28; cf. Figs. 23, 57 ). 

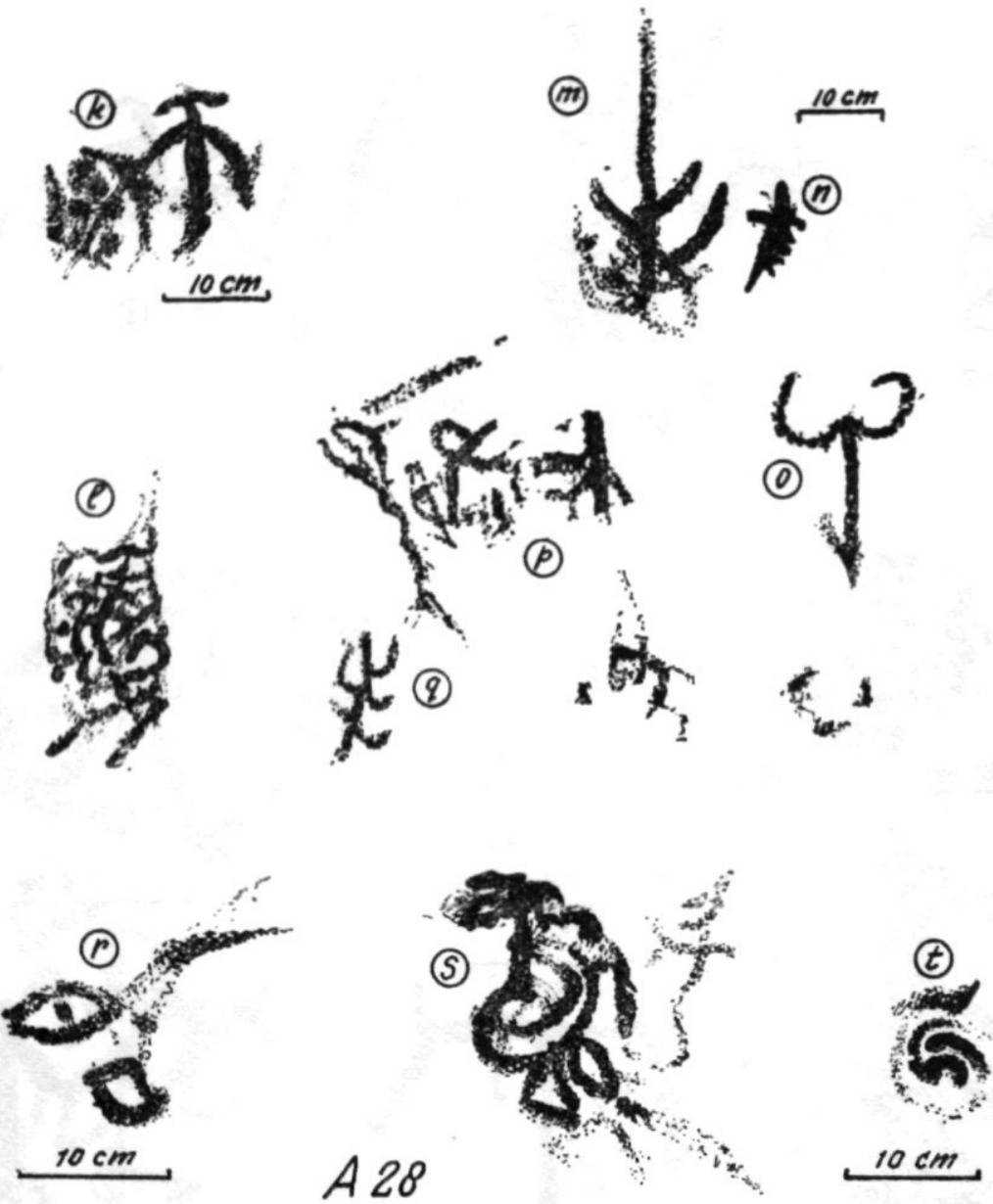

Fig. 22. Tekeningen uit dezelfde grot bij Quadirikiri, Aruba (A 28; vgl. Fig. 23, 57).

Fig. 22. Drawings from the same cave near Quadirikiri (A 28; cf. Figs. 23, 57). 


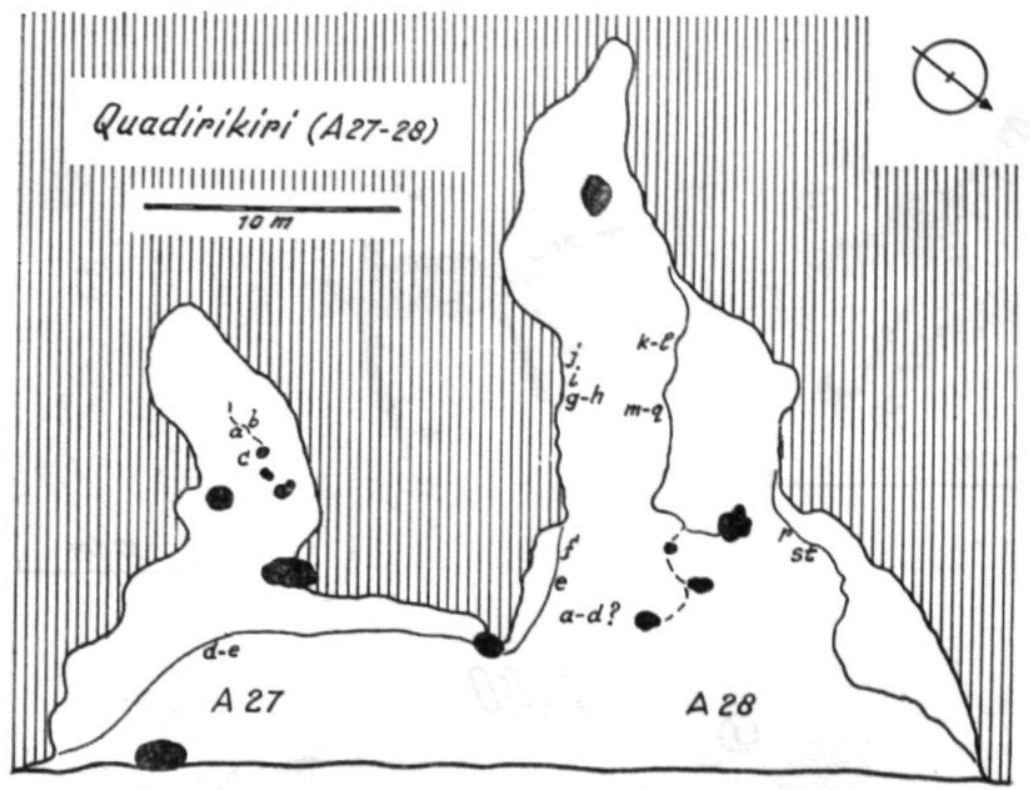

Fig. 23. Plattegrond van de abri bij Quadirikiri, Aruba (A 27-28), met vindplaatsen van rotstekeningen $(27 a-e ; 28 a-t)$. - De kalksteenrots is gearceerd; de druipsteenzuilen massief zwart. De rand van het overhangende deel is met een dikke lijn aangeduid; belangrijke reliëfverschillen van de zoldering met een dunne lijn, van de bodem met een gebroken lijn.

Fig. 23. Ground plan of the limestone abri near Quadirikiri, showing the locations of petrographs $(27 a-e, 28 a-\mathrm{t})$. Pillars of dripstone indicated by black dots.

(a)
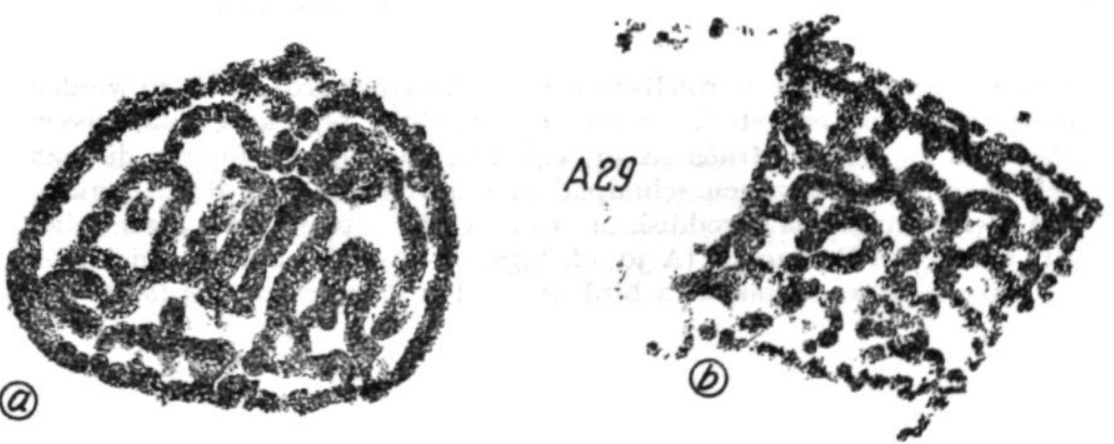

Fig. 24. Twee bruinachtige rode petrographieën van een diorietblok bij Macuarima, Santa Cruz, Aruba (A 29) (lengte van $a$ ruim $30 \mathrm{~cm}$, van $b$ omstreeks $15 \mathrm{~cm}$ ).

Fig. 24. Two reddish designs from Macuarima, near Santa Cruz (A 29) (max. diam. of $a$ about $30 \mathrm{~cm}$, of $b$ about $15 \mathrm{~cm}$ ). 

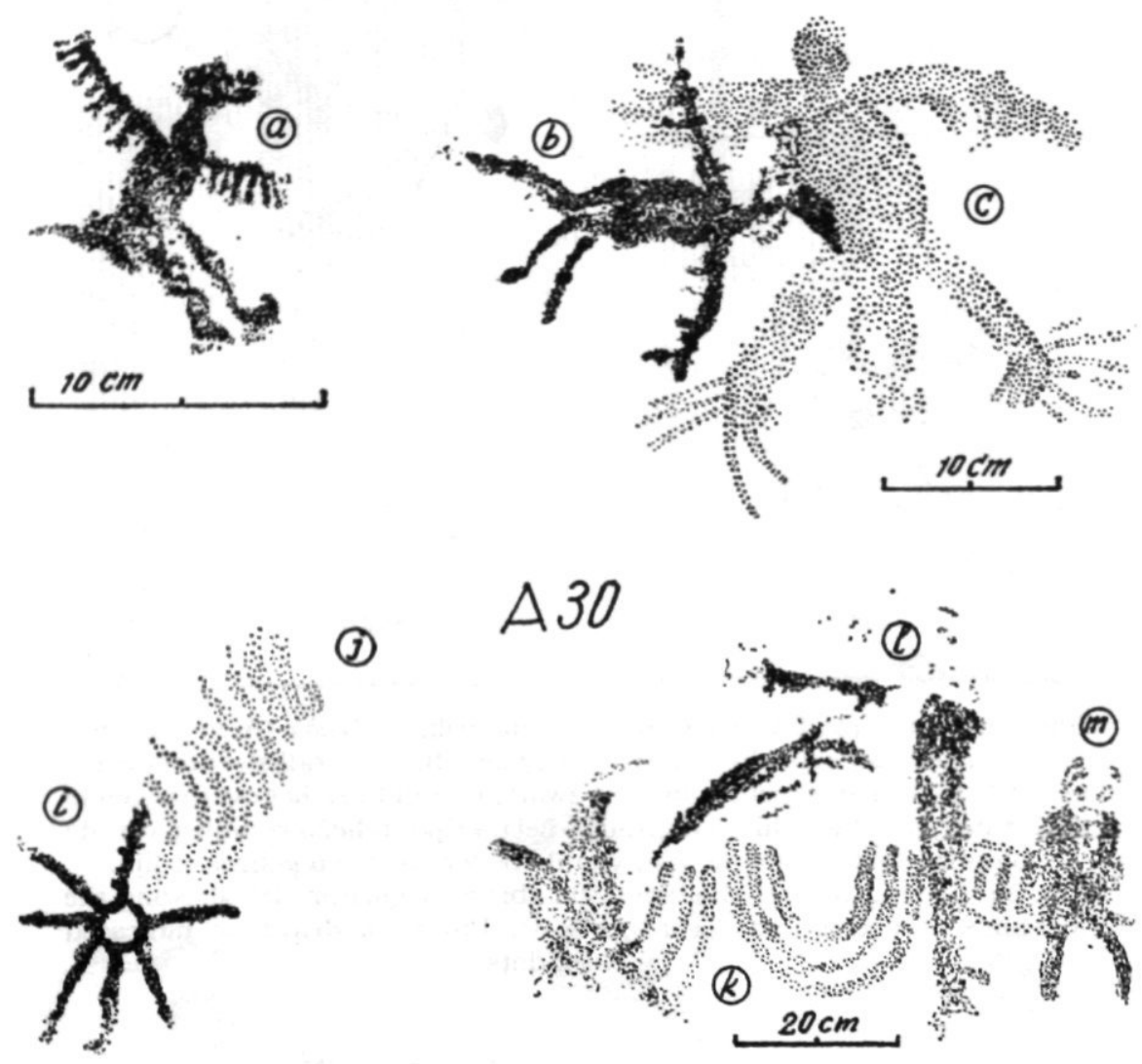

Fig. 25. Schilderingen in roodbruin en wit (gepuncteerd), zoals zij werden aangetroffen op een sterk uitgehold diorietblok bij Paraguaná, tussen Paradera en Noord, Aruba (A 30; vgl. Fig. 60-62), met figuren die aan een vogel $(a)$ en aan een schildpad of een leguaan $(b-c)$ doen denken. Fig. 25. Petrographs in reddish brown and white (punctated) from a diorite boulder at Paraguaná (A 30; cf. Figs. 60-62), with figures which look like representations of a bird $(a)$, and turtles or iguanas $(b-c)$. 

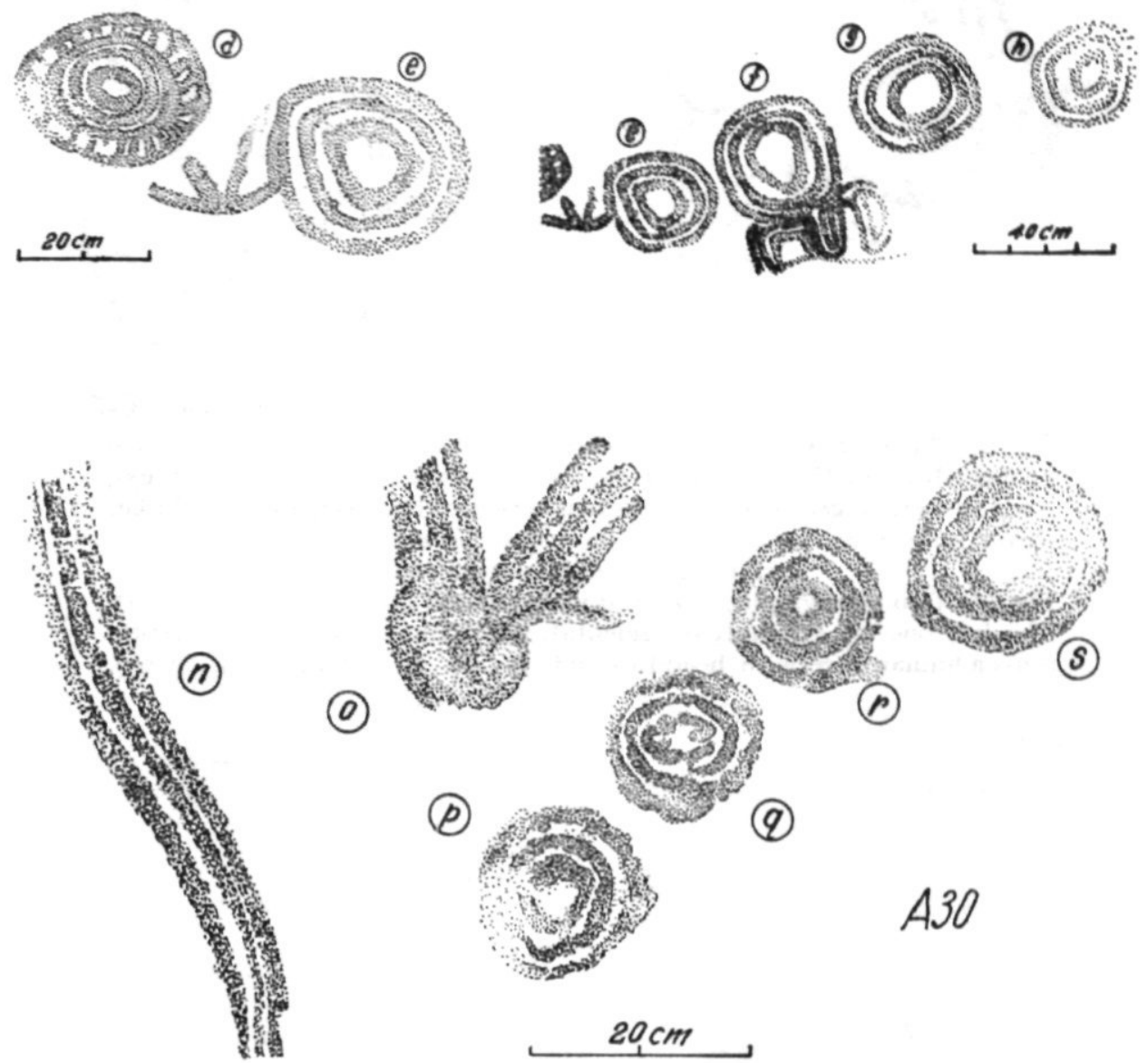

Fig. 26. Nog enkele andere tekeningen, met een witte kleurstof aangebracht, van dezelfde vindplaats, \Paraguaná, Aruba (A 30; vgl. Fig. 6o, 62). Fig. 26. More drawings in white,'from the same locality, Paraguaná (A 30; cf. Figs. 6o, 62). 

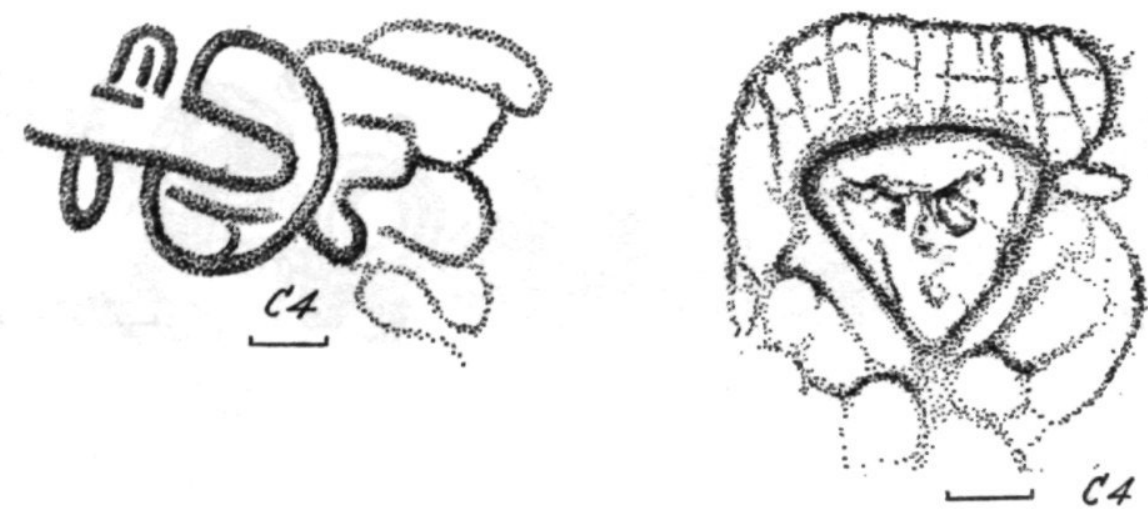

Fig. 27. Twee verweerde, in druipsteen gehouwen tekeningen, gevonden bij het abri van Hato, Curaf̧ao (C4; vgl. I, fig. 20-2I ; Fig. 29, 63-65), zoals zij werden gereproduceerd in het werk van HARToG, I96r. De linker figuur $(\gamma)$ is zuiver ornamentaal; de rechter $(\alpha)$ stelt misschien een menselijk gelaat met hoofdtooi voor.

Fig. 27. Two petroglyphs, engraved in weathered dripstone at Hato $\left(\mathrm{C}_{4}\right)$. The left one $(\gamma)$ is purely ornamental, the right one $(\alpha)$ probably represents a human face with headdress (cf. I, figs. 20-21; Figs. 29, 63-65).

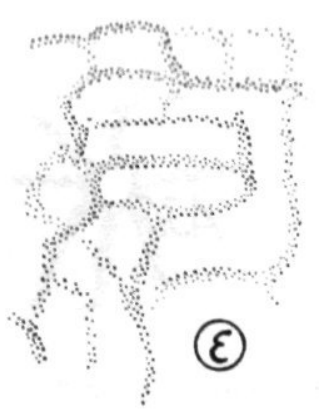

()
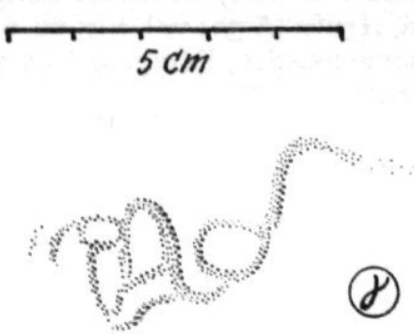

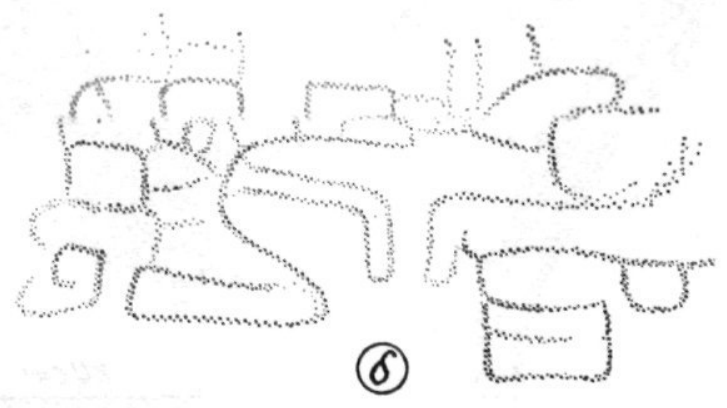

C4

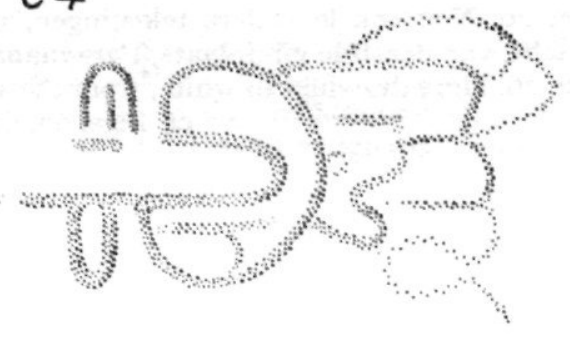

Fig. 28. Petroglyphen in verweerde druipsteen van het abri van Hato, Curaçao $\left(\mathrm{C}_{4} ;\right.$ vgl. Fig. 29, 63-65).

Fig. 28. Petroglyphs on weathered dripstone in the abri at ${ }^{7} H_{a}\left(\mathrm{C}_{4}\right.$; $\mathrm{cf}$. Figs. 29, 63-65). 

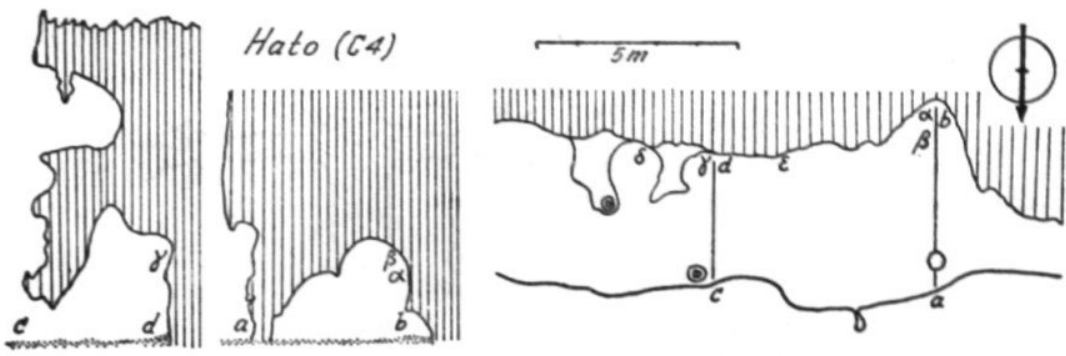

Fig. 29. Doorsneden en plattegrond van de abri van Hato, Curaçao $\left(\mathrm{C}_{4}\right)$. - De kalksteenrots is gearceerd; de rand van het overhangende deel van het terras is met een vette lijn aangeduid. De letters a-b en c-d hebben betrekking op de plaats waar de doorsneden gemaakt zijn; de Griekse letters op plaatsen waar de reliëfs werden gevonden.

Fig. 29. Cross sections (a-b, c-d) and ground plan of the abri of Hato $\left(\mathrm{C}_{4}\right)$; petrographs indicated by Greek characters.
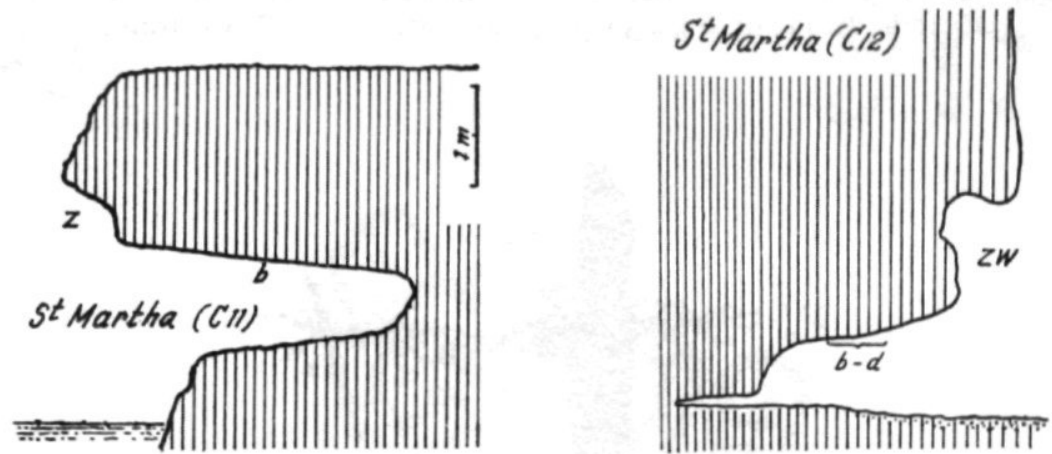

Fig. 3o. Doorsnede van de westelijke abri van Santa Martha, Curaf̧ao (C II); een opgeheven brandingsnis tegen het dak waarvan tekeningen voorkomen (vgl. Fig. 32-33).

Fig. 30. Cross section of the western abri of Santa Martha (C II ; cf. Figs. 32-33).

Fig. 31. Doorsnede van de oostelijke abri van Santa Martha, Curafao (C12 ; vgl. Fig. 34).

Fig. 31. Cross section of the eastern abri of Santa Martha (C 12; cf. Fig. 34). 


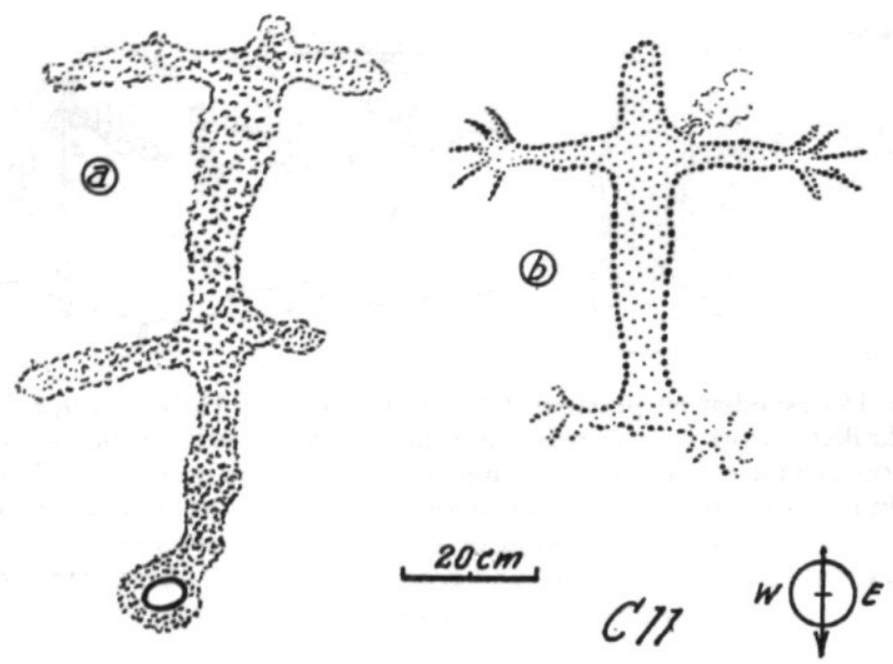

Fig. 32. Veldschetsen van de twee rotstekeningen van de westelijke abri van Santa Martha, Curaçao (C II ; vgl. Fig. 30, 3I); $b$ volgens J. G. DE JoNG.

Fig. 32. Field sketches of the petrographs in the western abri of Santa Martha (C II ; cf. Figs. 30, 33); $b$ according to J. G. DE Jong.

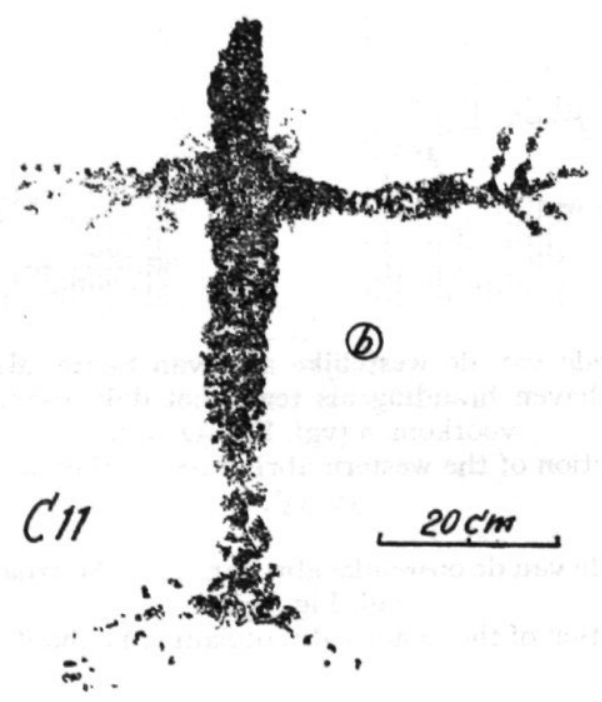

Fig. 33. Petrografie van Santa Martha, Curaçao (C II b). (Getekend naar een foto van P. A. VAN DER WERF, vgl. Fig. 66).

Fig. 33. Petrograph at Santa'Martha (C 1 I $b$; cf. Fig. 66). 


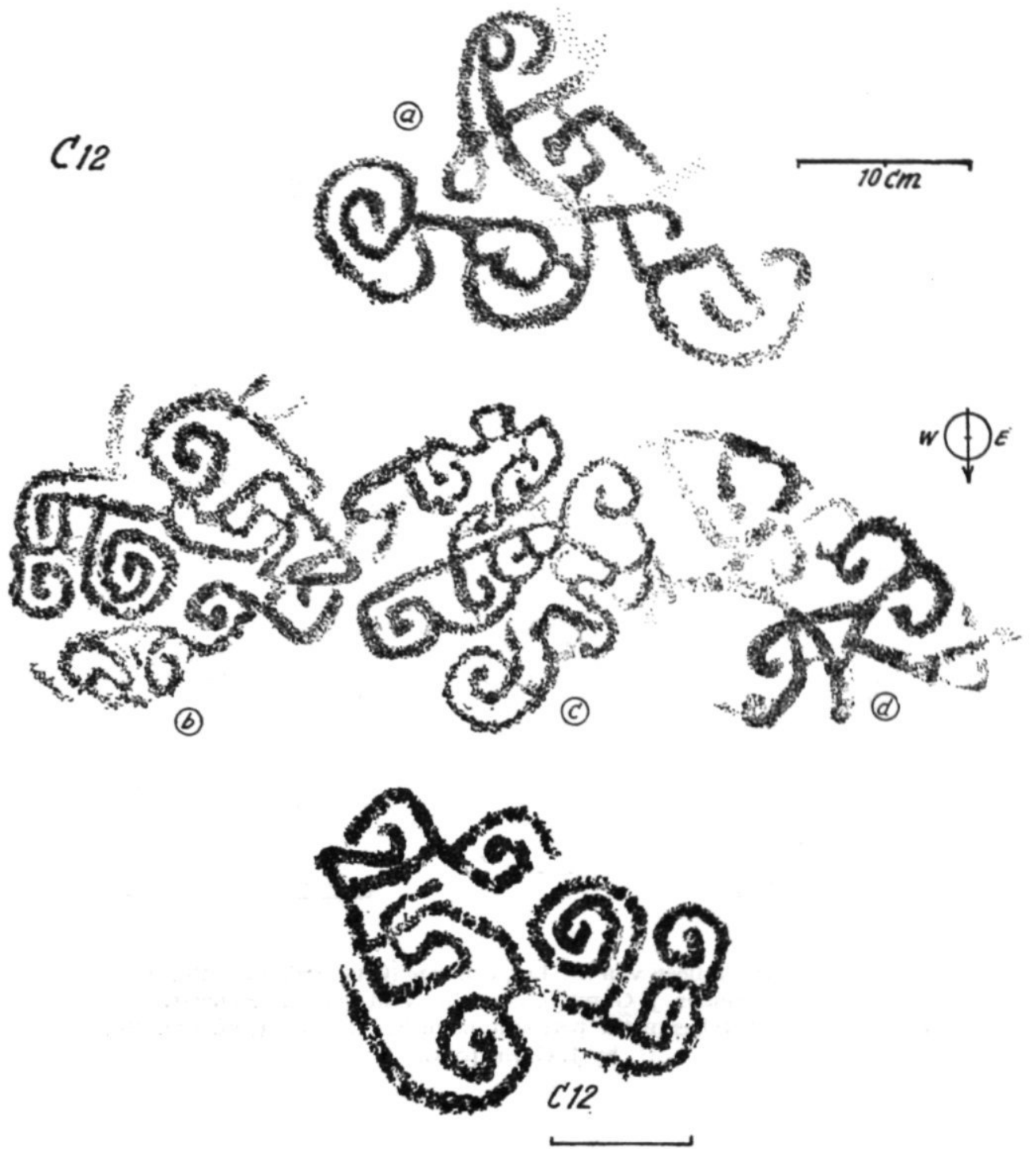

Fig. 34. Hetgeen nog te zien was van een reeks tekeningen op het plafond van een laag abri ten oosten van de baai van Santa Martha, Curaçao (C12; vgl. Fig. 3I). De figuur $a$ is op ro cm afstand rechts van $d$ gelegen. Onderste figuur: $b$ zoals afgedrukt in het werk van HARTOG, 196r.

Fig. 34. Ornamental rock drawings which are still visible, albeit indistinctly, on the ceiling of the limestone abri of Santa Martha Bay (C I2; cf. Fig. $3 \mathrm{I}) ; a$ is situated ro $\mathrm{cm} \mathrm{E}$ of $c$. Lower figure: $b$ as reproduced in HARTOG, I961. 

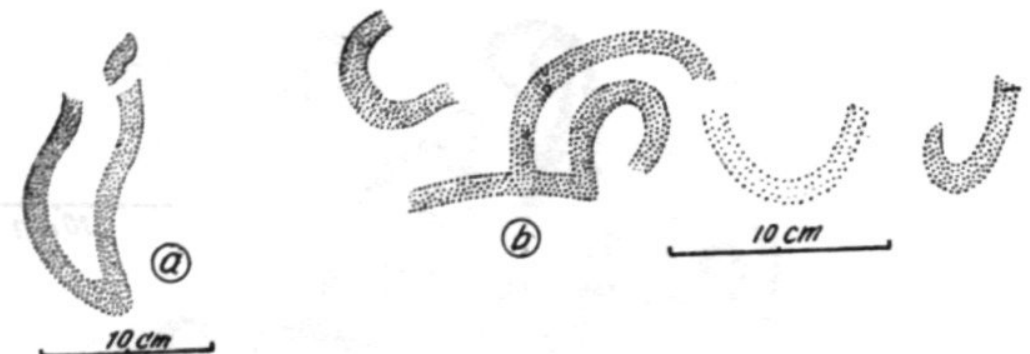

(b)

$10 \mathrm{~cm}$

$10 \mathrm{~cm}$
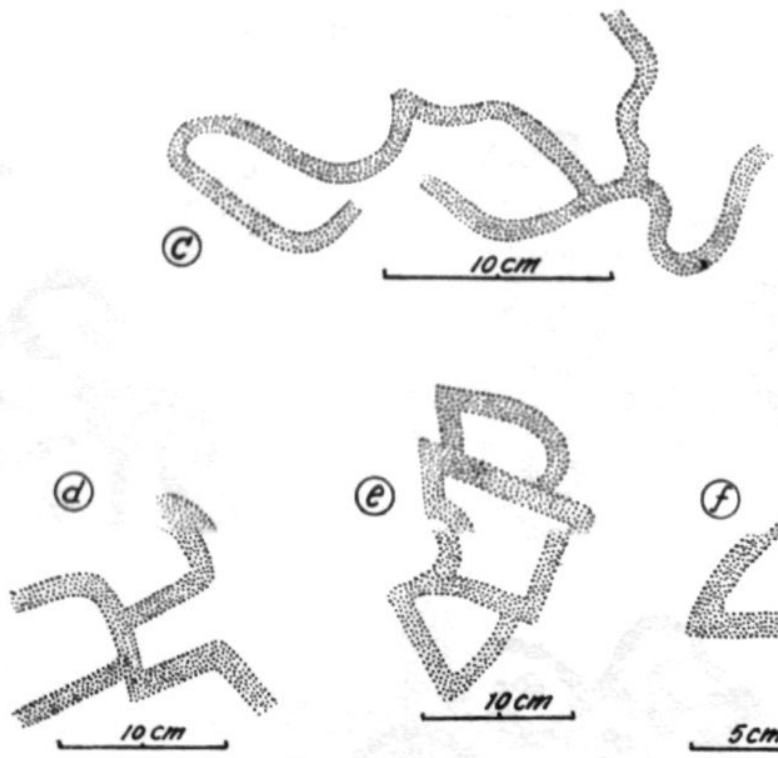

(e)
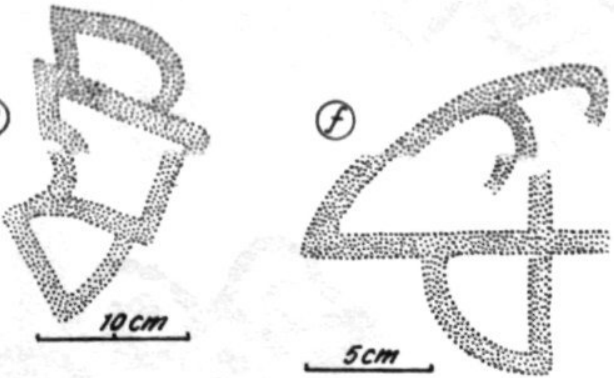

Fig. 35. De petrografieën van St. Jan, Curaf̧ao (C 13; vgl. Fig. 36), zoals zij door de vinder, J. G. DE JONG, in het veld werden geschetst.

Fig. 35. Field sketches of the petrographs of St. Jan (C 13; cf. Fig. 36), by J. G. DE JONG. 


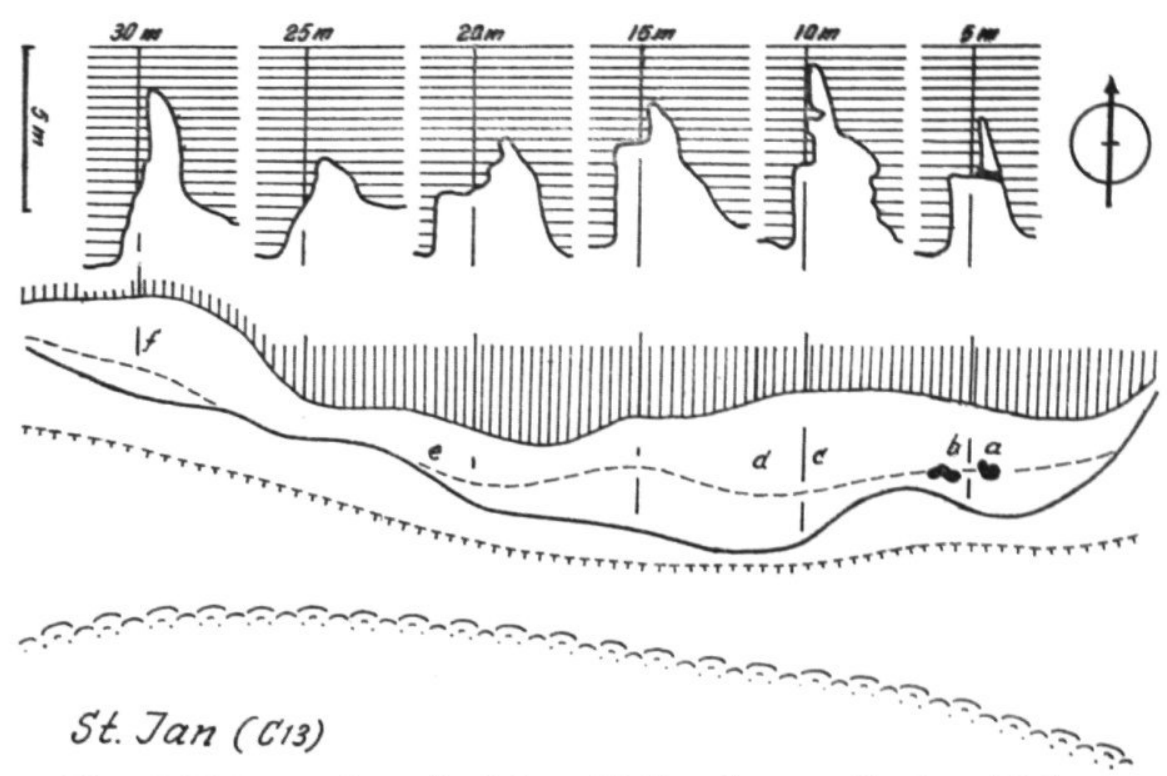

Fig. 36. Plattegrond van de abri van St. Jan, Curafao (C 13), met 6 doorsneden welke op afstanden van 5 meter werden gemaakt. Te beginnen met de grens van het gesteente zijn achtereenvolgens aangeduid: de drempelrand (gebroken lijn), de grens van het overhangende gesteente (gesloten lijn), rand van het terras, en kustlijn. Naar J. G. DE JoNG. Fig. 36. Ground plan of the limestone abri of St. Jan (C 13), together with six cross sections. Below the upper edge of the limestone terrace (thick line), the lower edge of the terrace and the shoreline are indicated. J. G. DE JONG.
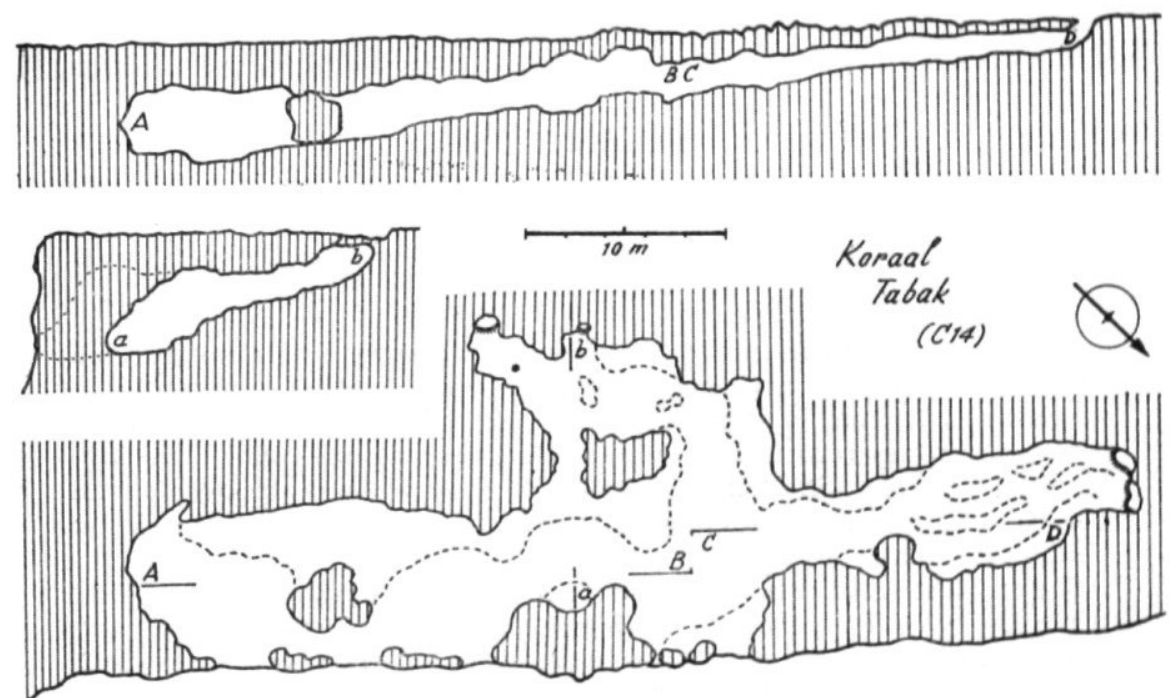

Fig. 37. Plattegrond, lengte-doorsnede (A-D) en dwars-doorsnede (a-b) van de Grot van Koraal Tabak, Curą̧ao (C I4), waarin (bij de stip linksonder van $b$ ) een bewerkte stalagmiet (vgl. Fig. 38 en 67 ) werd gevonden. Het dak van de grot is uiterst dun en vertoont vele gaten, waarvan er slechts twee bij D en twee bij b zijn aangeduid. Deze grot ligt aan de rand van het kalksteenterras, en is langs de steilrand door verscheidene openingen ontsloten. Naar een tekening van J. G. DE JoNG.

Fig. 37. Ground plan with longitudinal section (A-D) and lateral section (a-b) of the cave of Koraal Tabak ( $\left.\mathrm{C}_{14}\right)$, in which a carved stalagmite (cf. Figs. $3^{8}$ and 67 ) was found. After a survey by J. G. DE Jong. 


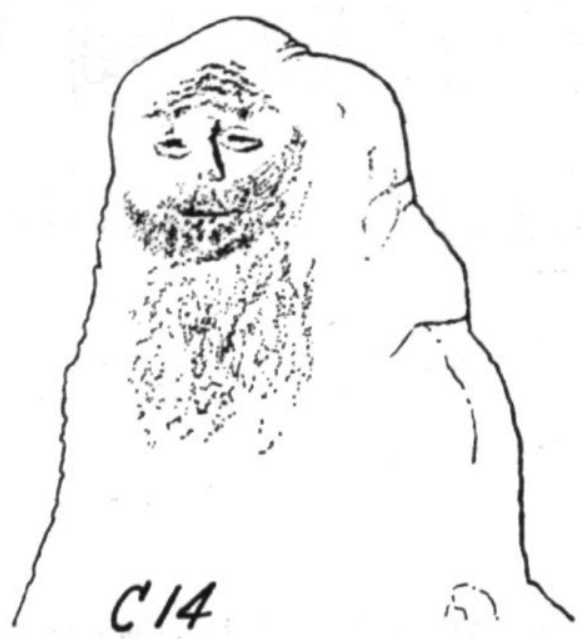

Fig. 38. De bewerkte stalagmiet welke door Mevrouw S. DE JonG-van HEUZEN in de Grot van Koraal Tabak, Curaçao (C I4) werd gevonden. Alleen de neus, de mond en de koffieboon-ogen zijn kunstmatig aangebracht; de plooien in het voorhoofd en het baardige voorkomen zijn veroorzaakt door het natuurlijk reliëf van de druipsteen. (Getekend naar een foto van C. J. Du Ry, vgl. Fig. 67).

Fig. 38. Carved stalagmite in the cave of Koraal Tabak (C 14). Only the coffee-bean eyes, the nose and the mouth are artificial (cf. Fig. 67).

\section{SUMMARY}

\section{LINEAR ROCK DESIGNS OF CURAÇAO, ARUBA AND BONAIRE}

\section{Part III}

In the second part of Linear Rock Designs of Curaçao, Aruba and Bonaire (1957), the hope was expressed that an account of the petrographs of Spelonk and Onima, in Bonaire, would soon follow as the third part of this documentary record. However, at that time no one could have supposed that description of those sites would have to be postponed for the sake of publication of a number of observations made in the interval by inhabitants of the islands.

The greatest surprise in this connection was an album which was offered to me by IVAN TJON SIE FAT, telegraphist at Oranjestad, Aruba, and which contained a large number of photographs of Aruban rock drawings as yet unknown to me, together with pictures of some well-known sites which were so much clearer than those already reproduced that it was decided also to include these in the present, third part of the work.

Meanwhile, members of the Natural Science Study Group of the Netherlands Antilles had made further discoveries in Curaçao, which have also 


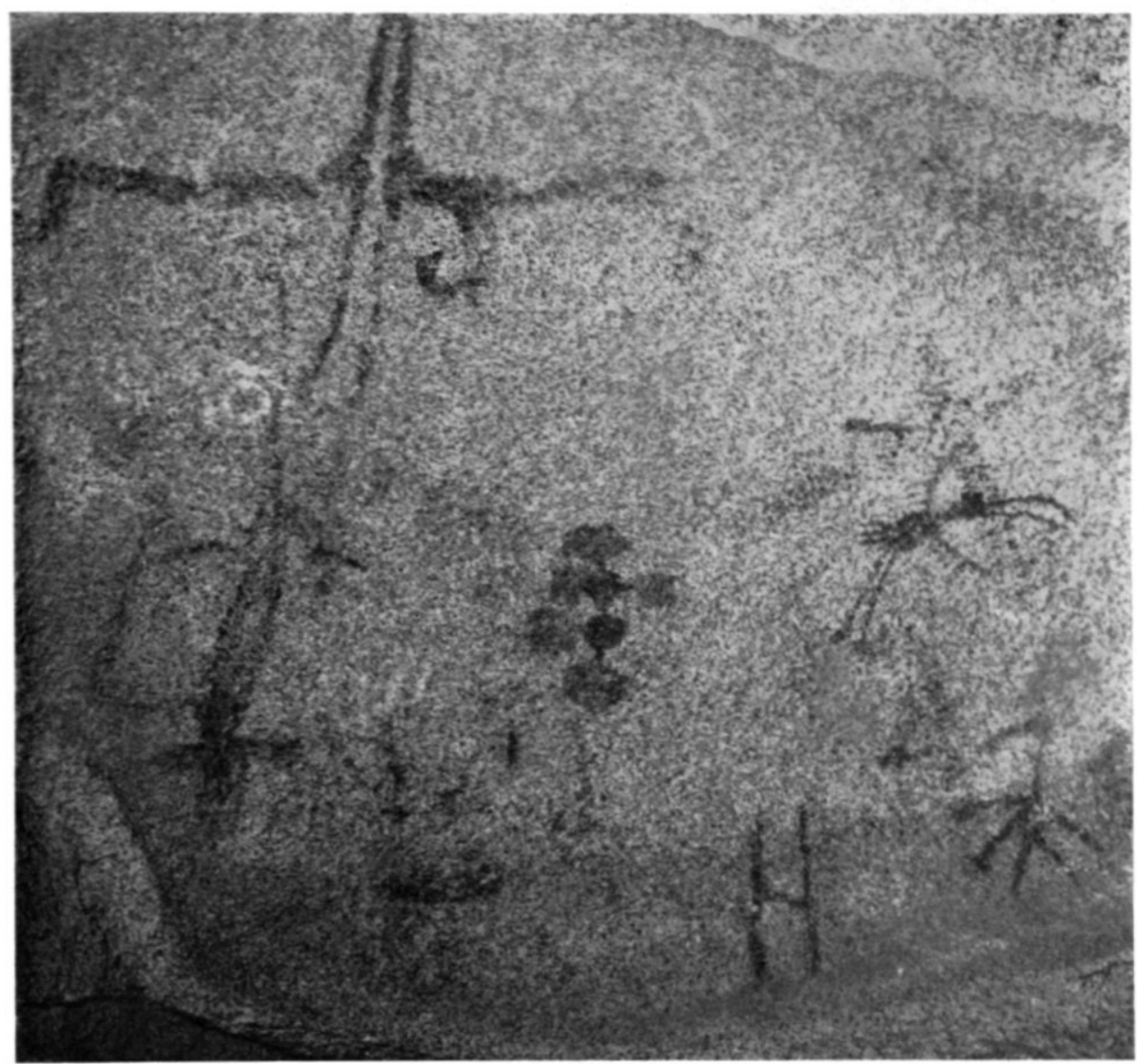

Fig. 39. De tekeningen op het diorietblok van Piedra Plat, Aruba (A 3 ; vgl. Fig. 5).

Fig. 39. The drawings of Piedra Plat (A 3; cf. Fig. 5).

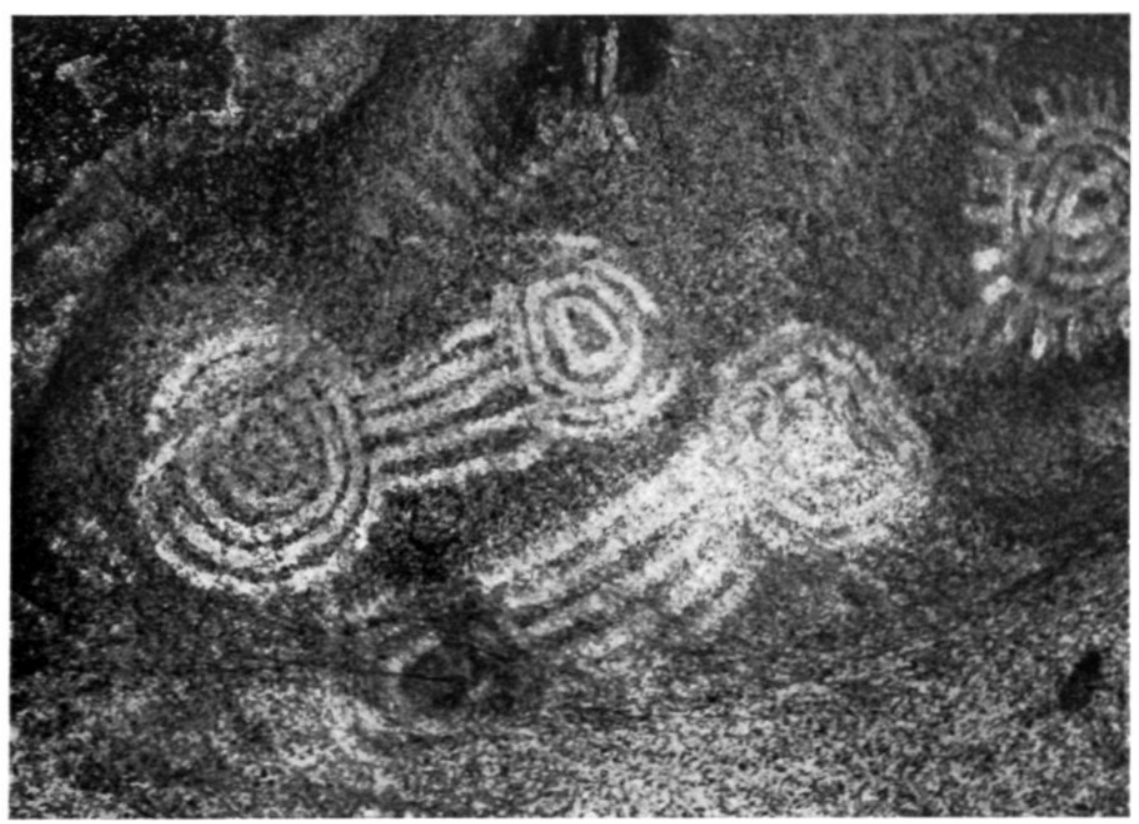

Fig. 40. Witte ornamentale tekeningen bij Rooi Arikok, Aruba (A 7; vgl.

n $\quad \ldots \ldots$ I, fig. $12,34-36) ., \ldots, \ldots, \ldots$ 


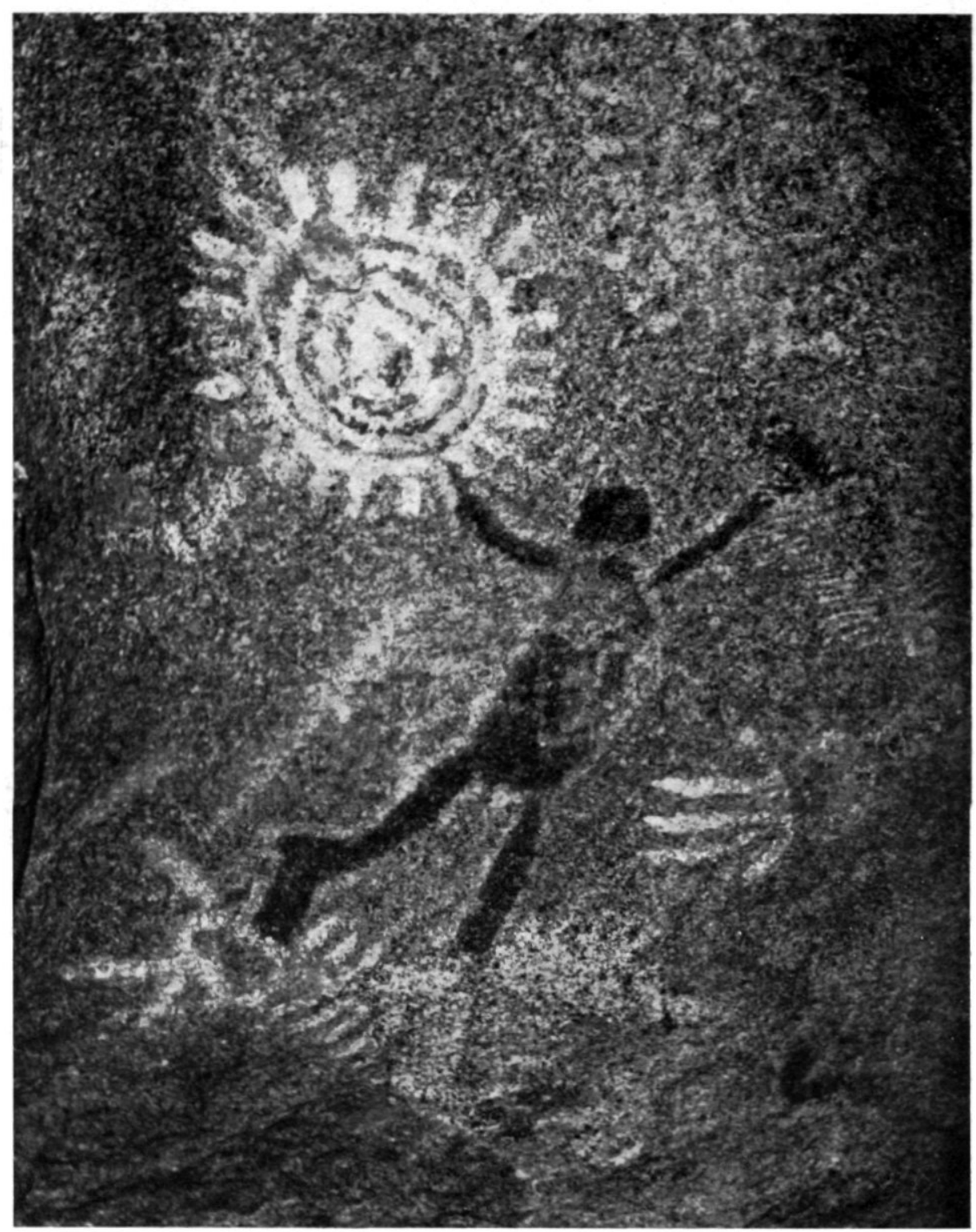

Fig. 4I. Een beschildering in wit (gestippeld) en rood op de holle wand van een groot blok kwartsdioriet bij Rooi Arikok, Aruba (A $7 d-i$; vgl. II, fig. I2, 34-35). De 'rechtervoet' is verdwenen door afschilfering van het gesteente. Fig. 4I. Painting in white and red near Arikok (A $7 d-i$; cf. II, figs. I2, 34-35). The 'right foot' of the 'Amerindian' has vanished because the rock wall has flaked off.

Alle Arubaanse foto's welke in dit artikel zijn gereproduceerd (Fig. 39-6I) werden vervaardigd door IVAN TJON SIE FAT.

All photographs of Aruba rock drawings which are reproduced here (Figs. 39-6I) have been made by I. TJON SIE FAT. 


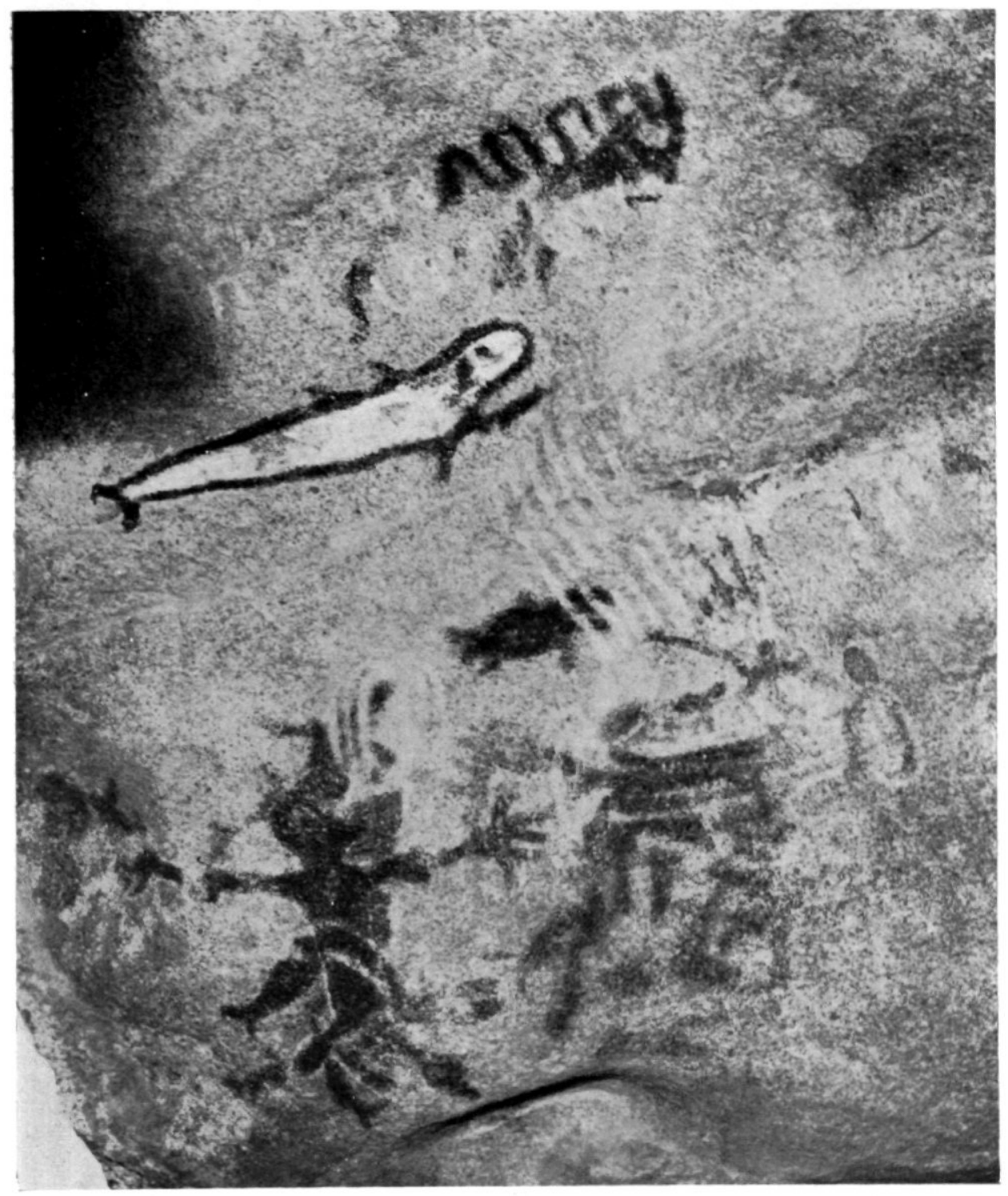

Fig. 42. Tekeningen in wit, roodbruin en bruinachtig rood, naast en over elkaar heen aangebracht op een diorietwand bij Rooi Arikok, Aruba (A 8 I-7; vgl. II, fig. I3-I 4, 37-39); men zou er afbeeldingen van een vis, een schildpad en een mens in kunnen herkennen.

Fig. 42. Paintings in white, reddish brown and brownish red, on a diorite rock wall at Rooi Arikok (A $8{ }_{-7}$; cf. II, figs. 13-14, 37-39); pictures of a fish, a turtle, and a human being may be discerned. 


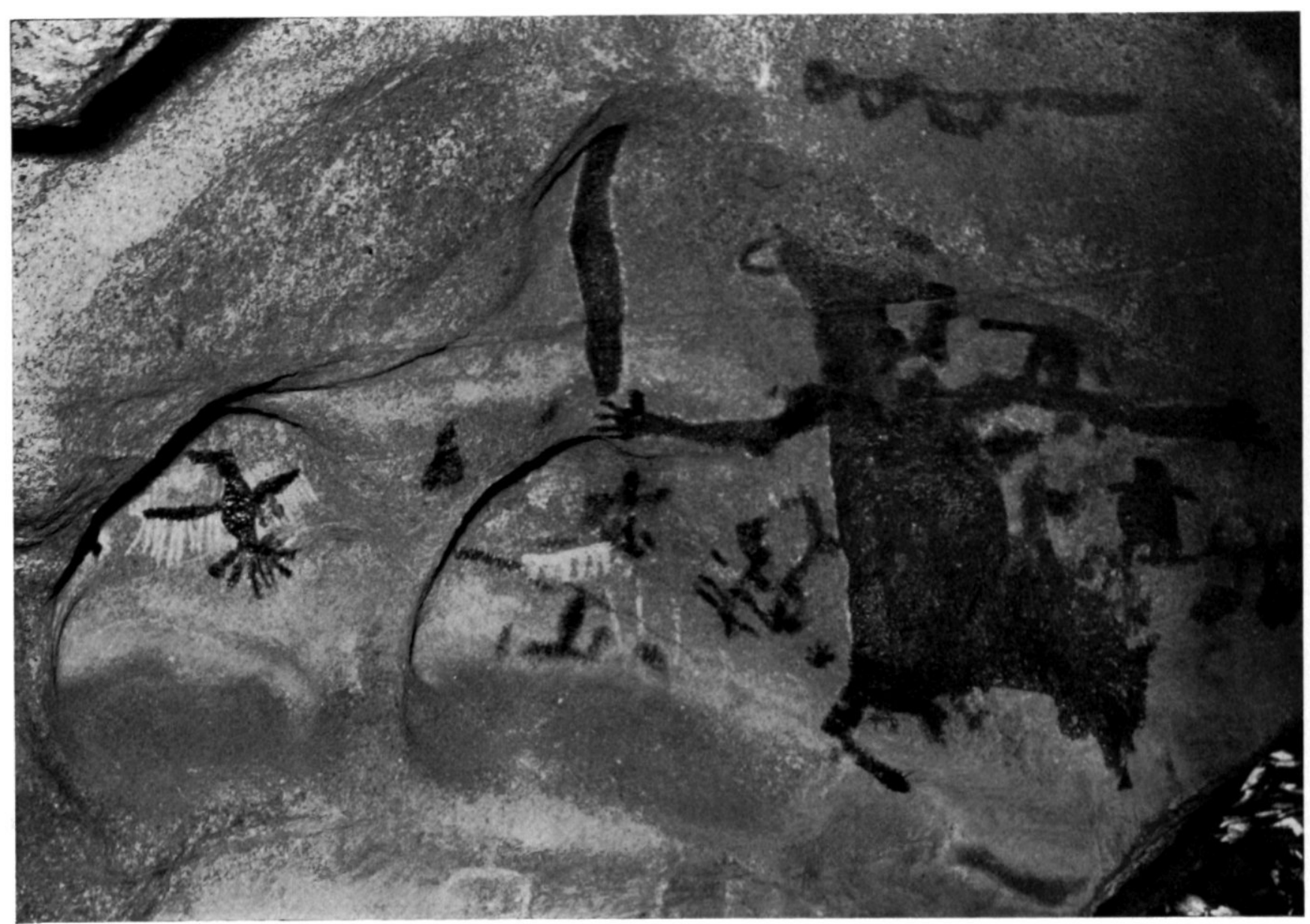

Fig. 43. Opvallende figuren in rood, bruin en wit op een onregelmatig gewelfde wand van een groot, uitgehold diorietblok bij Rooi Arikok, Aruba (A 8 I6-23; vgl. II, fig. 13, I6-18, 33, 40). De vliegende vogel heeft een witomlijnd bruin lichaam, witte vleugelveren en rode staartpennen. Ook de 'met een knots zwaaiende indiaan' was oorspronkelijk witomlijnd; op verscheidene plaatsen is de kleurstof hier echter door afschilfering van het gesteente verdwenen. Zoals op vele andere plaatsen zijn ook hier twee of drie schilderingen over elkaar heen aangebracht.

Fig. 43. Striking remnants of paintings in red, reddish brown and white on a large diorite boulder near Arikok (A 8 I6 23; cf. II, figs. I3, I6-18, 33, 40). The 'duck' has a brown body outlined in white, white wing feathers and reddish, expanded tail feathers. The 'Amerindian with club' has been damaged by weathering of the rock. 


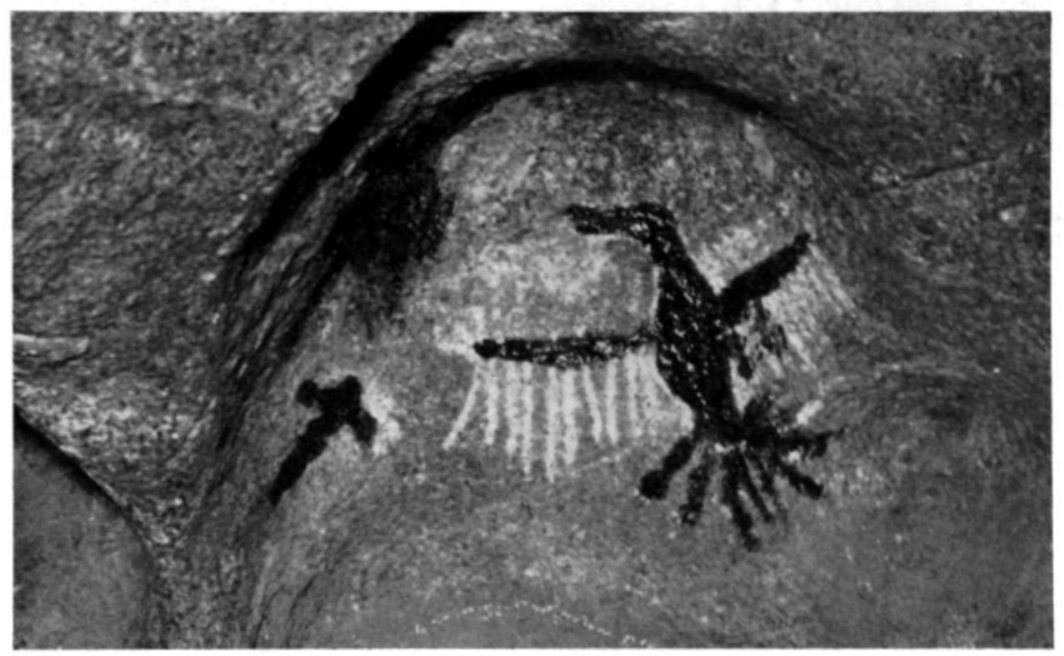

Fig. 44. De 'opvliegende eend' van Arikok, Aruba (A 8 I6; vgl. Fig. 43, en II, fig. 16, 40).

Fig 44. The 'duck taking wing' of Arikok A 8 I6; cf. Fig. 43, and Il, figs, I6, 40).

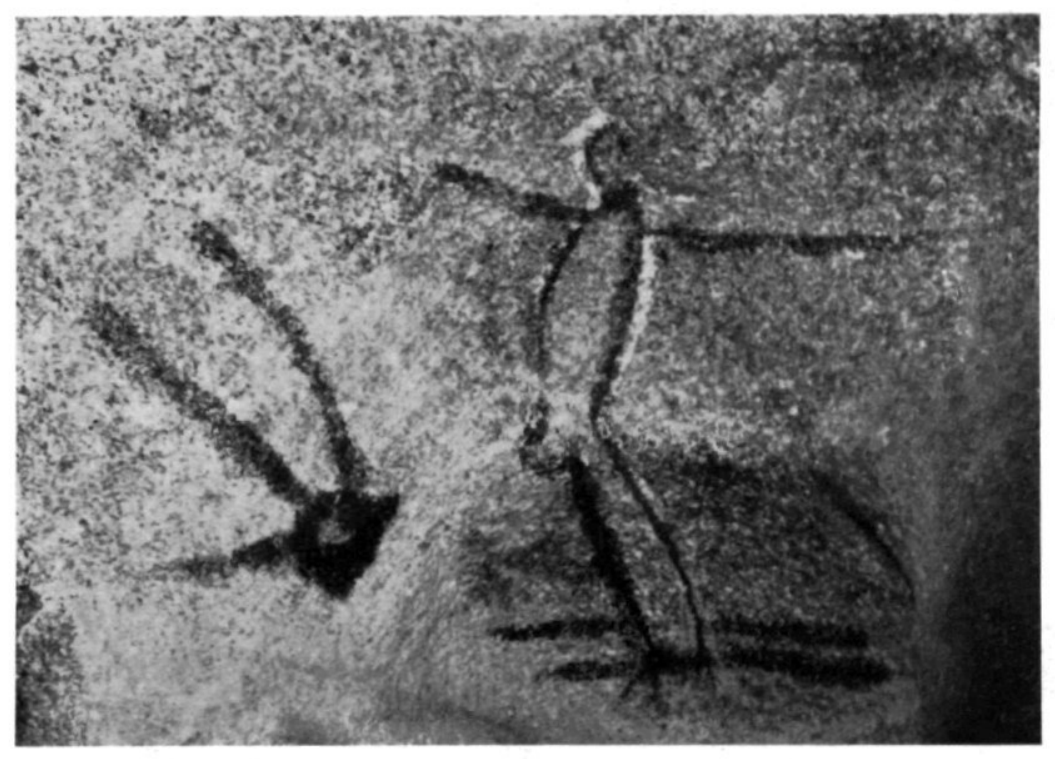

Fig. 45. De 'jabiru' van Arikok (A 88 ; vgl. II, fig. 17, 4I).

Fig. 45. The 'stork-like bird' of Arikok (A 88 ; cf. II, figs. I7, 4I). 


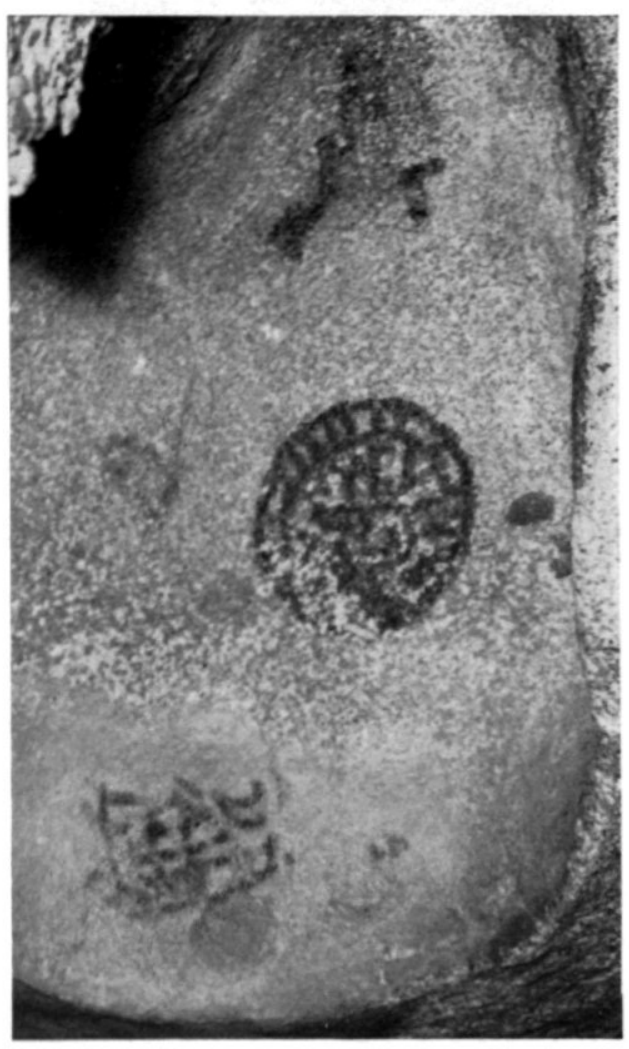

Fig. 46. Bruinachtig rode tekeningen in de holte van een kleiner diorietblok bij Rooi Arikok, Aruba (A 9; vgl. Fig. 6, en II, fig. I9). Fig. 46. Remnants of drawings in brownish red, on a much smaller diorite boulder near Arikok (A 9; cf. Fig. 6, and II, fig. I9).

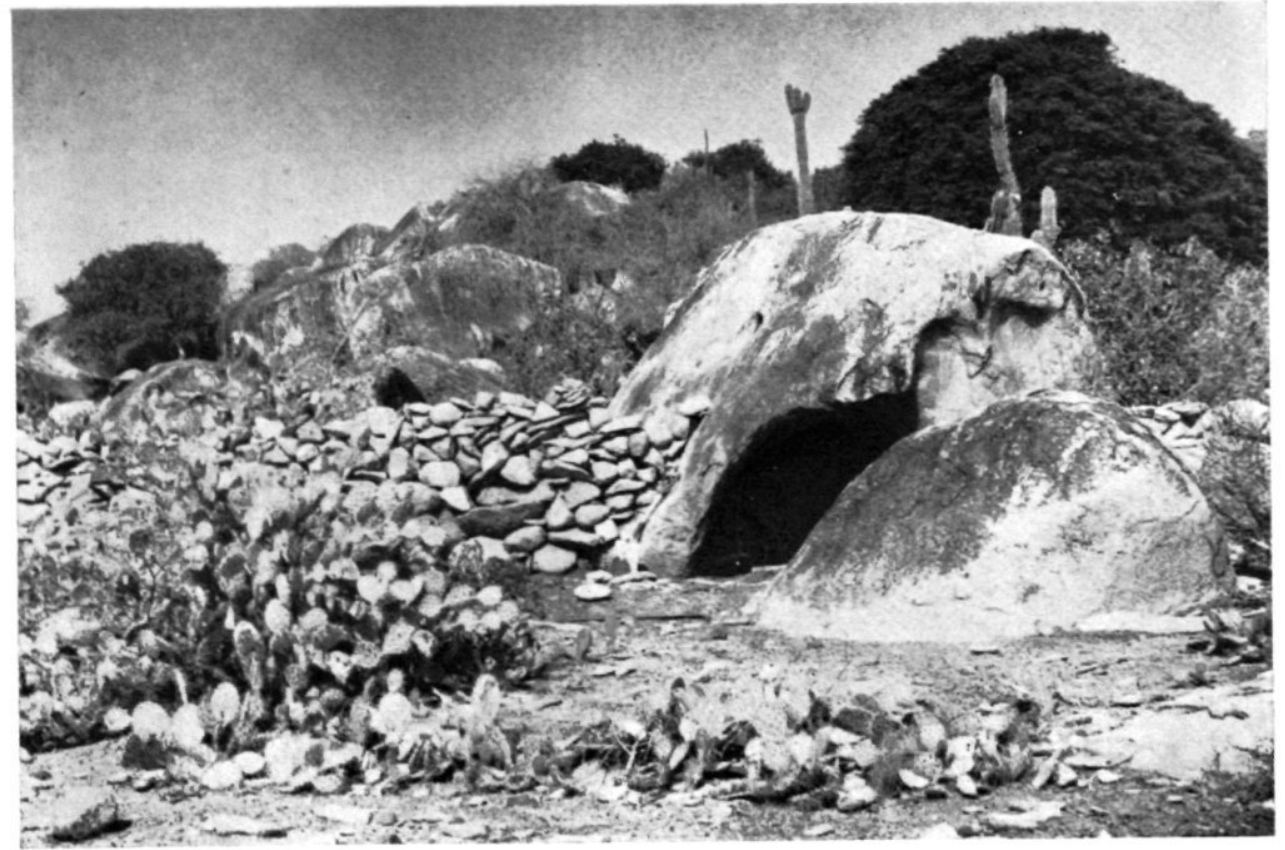

Fig. 47. Klein diorietblok, met verweringsholte op het Westen, in een trankeer bij Arikok, Aruba (A I2). Achter het los gestapelde muurtje ligt het terrein met de grote blokken waar de andere vindplaatsen van Arikok gelegen zijn.

Fig. 47. Small diorite boulder (A I 2), hollowed out on its west side, in a low rock wall behind which the previously-mentioned Arikok localities are situated. 


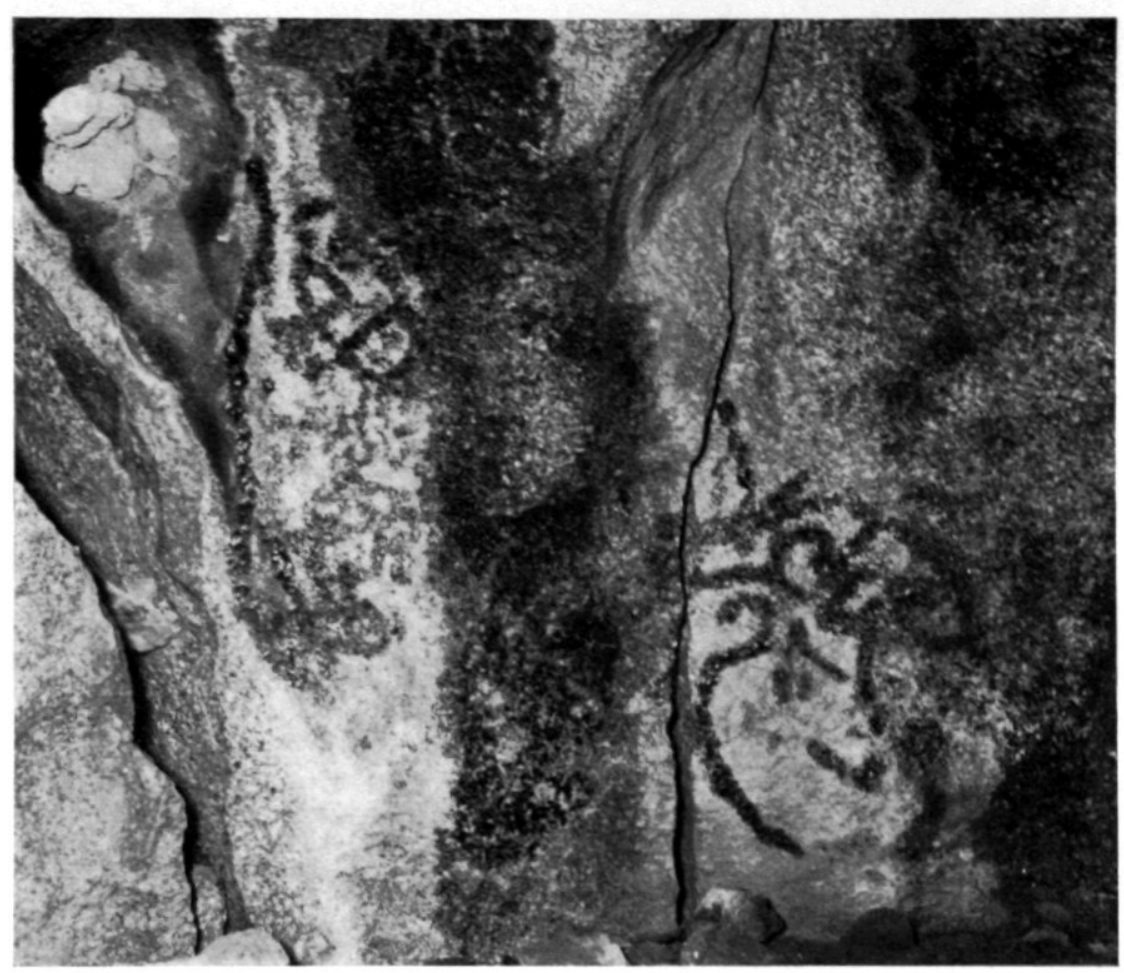

Fig. 48. Resten van bruin-rode rotstekeningen op het hieronder afgebeelde diorietblok van Babijn, Aruba (A I4; vgl. Fig. 9).

Fig. 48. Remnants of drawings in a brownish-red colour in a hollowed boulder at Babijn, reproduced below (A I4; cf. Fig. 9).

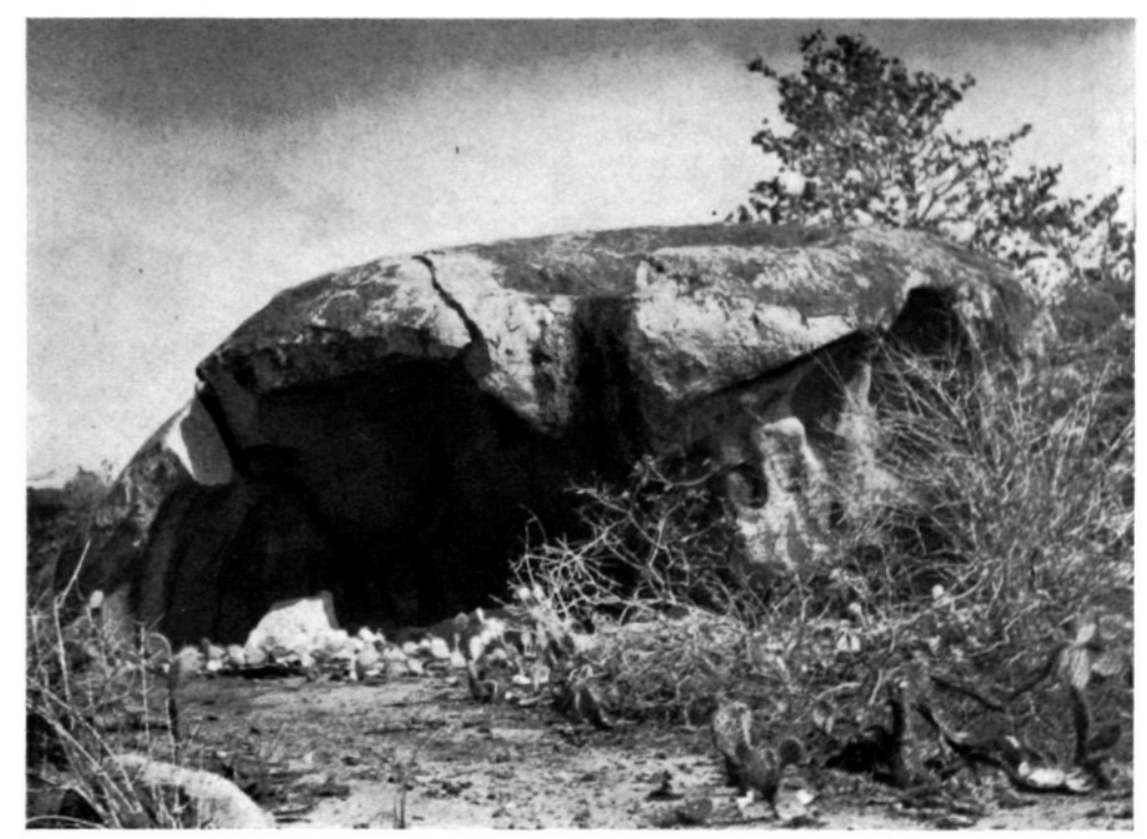

Fig. 49. Het uitgeholde diorietblok van Babijn, Aruba (A I4) waarin de hierboven afgebeelde tekeningen werden gevonden.

Fig. 49. The diorite block of Babijn (A I4), hollowed by weathering, in which the designs shown above are to be found. 


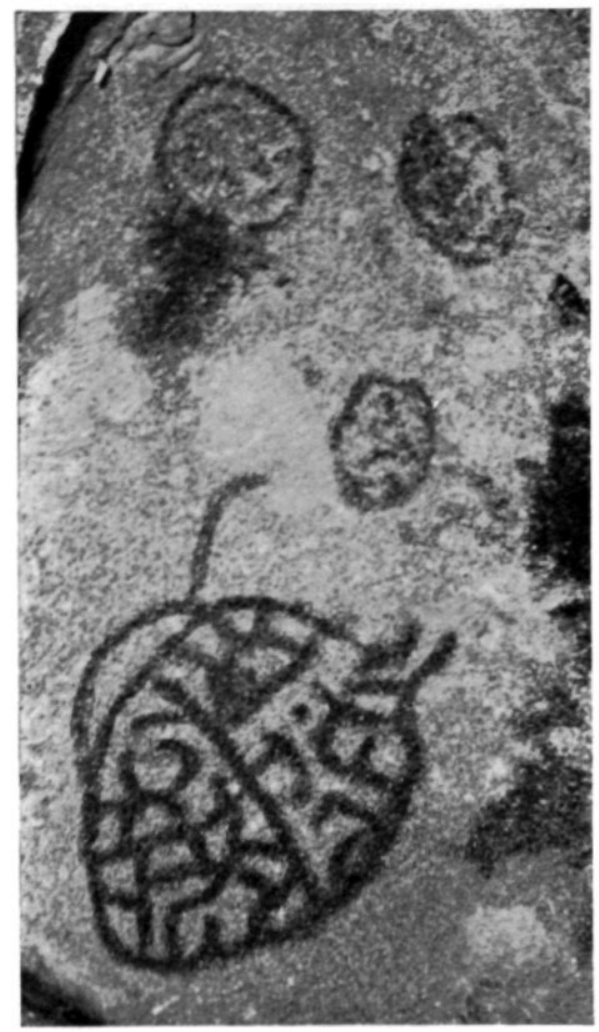

Fig. 5o. Bruin-rode tekeningen in een ondiepe verweringsholte van het hieronder afgebeelde stuk kwartsdioriet bij Paradera, Aruba (A I6; vgl. Fig. II).

Fig. 5o. Remains of linear rock designs in brownish red at the site at Paradera shown below (A I6; cf. Fig. II).

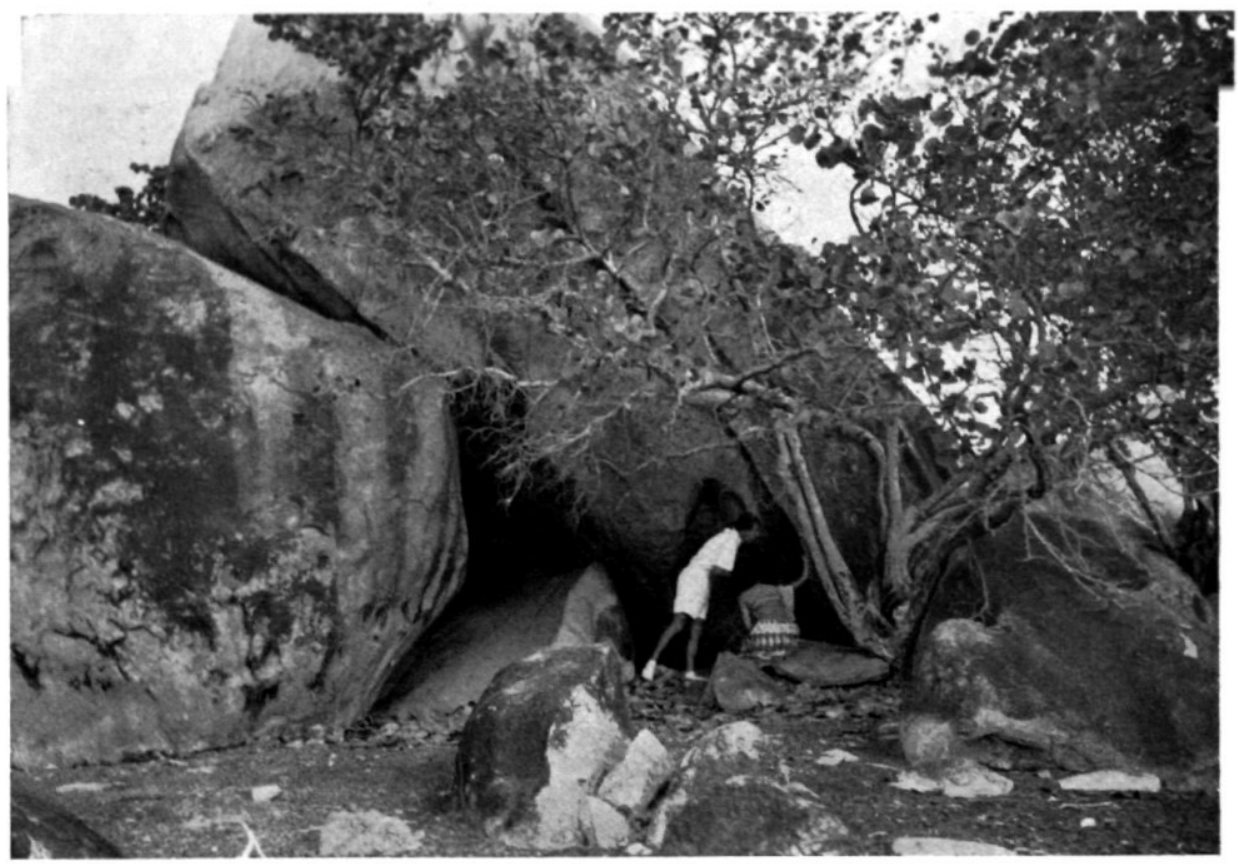

Fig. 5r. Het diorietblok van Paradera, Aruba (A r6). Ad Stenzen kijkt naar de hierboven afgebeelde tekeningen.

Fig. 5I. Admiring the designs on a large piece of quartz diorite at Paradera (A I6), represented in Fig. 5o. 


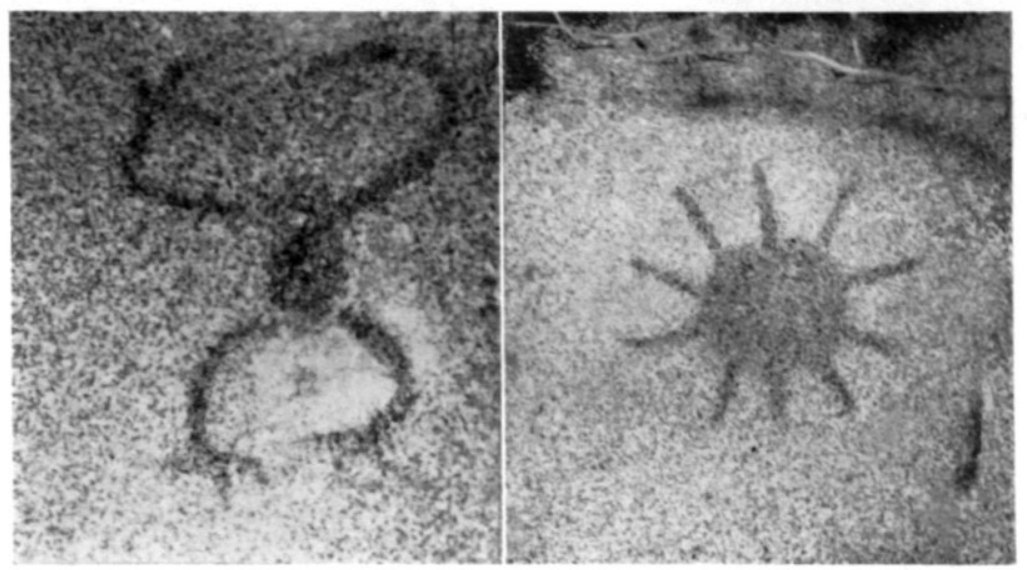

Fig. 52. Figuren in de beschuttende uitholling van een diorietblok bij Paradera, Aruba (A I 8; vgl. Fig. I3): links een 'kikker' waarvan elke poot drie tenen lijkt te hebben (I $8 a$ ); rechts een 'zon' (I $8 c$ ).

Fig. 52. Drawings on diorite at Paradera ( $A_{1} 8$; cf. Fig. 13$)$; the left one is possibly a 'frog' motif in brownish red, apparently with three 'toes' on each foot; right, a 'sun' in orange red.

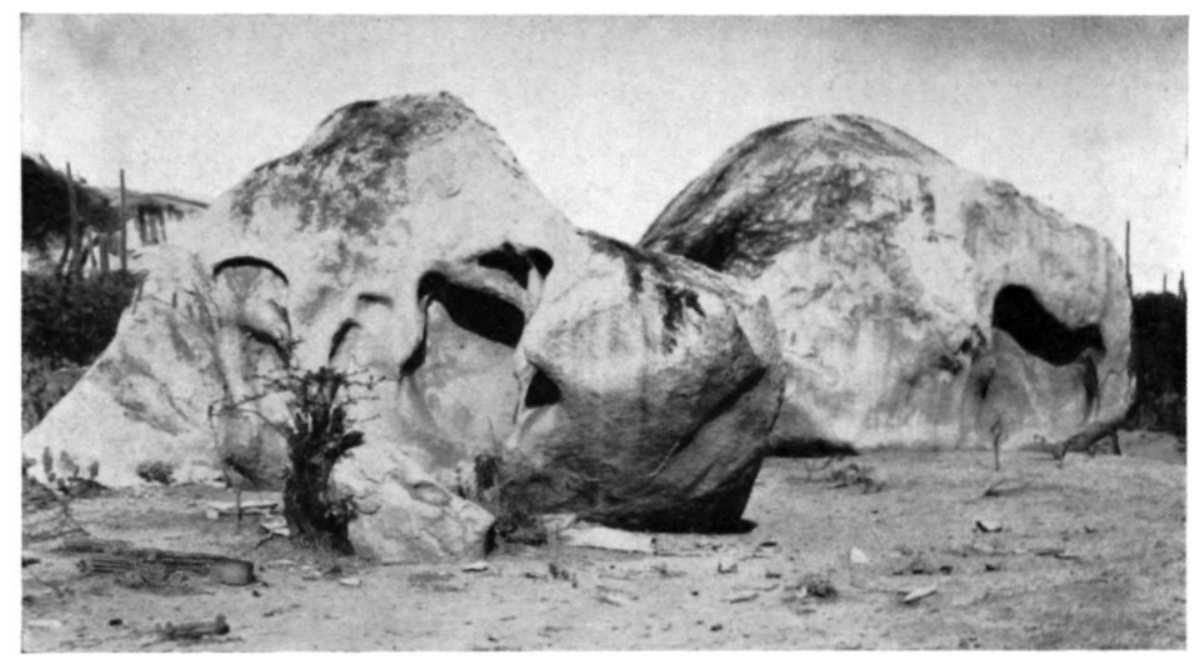

Fig. 53. Twee diorietblokken bij Casibari, Aruba, met verweringsholten aan hun zuidwest-zijde, waarvan de meest rechtse de tekeningen bevat welke op de volgende bladzijde staan afgebeeld $\left(\begin{array}{ll}A & 20\end{array}\right)$.

Fig. 53. Two diorite boulders at Casibari, with their southwestern sides hollowed out by rock weathering. The small cave in the blackground contains the drawings reproduced on the next page (A 20). 


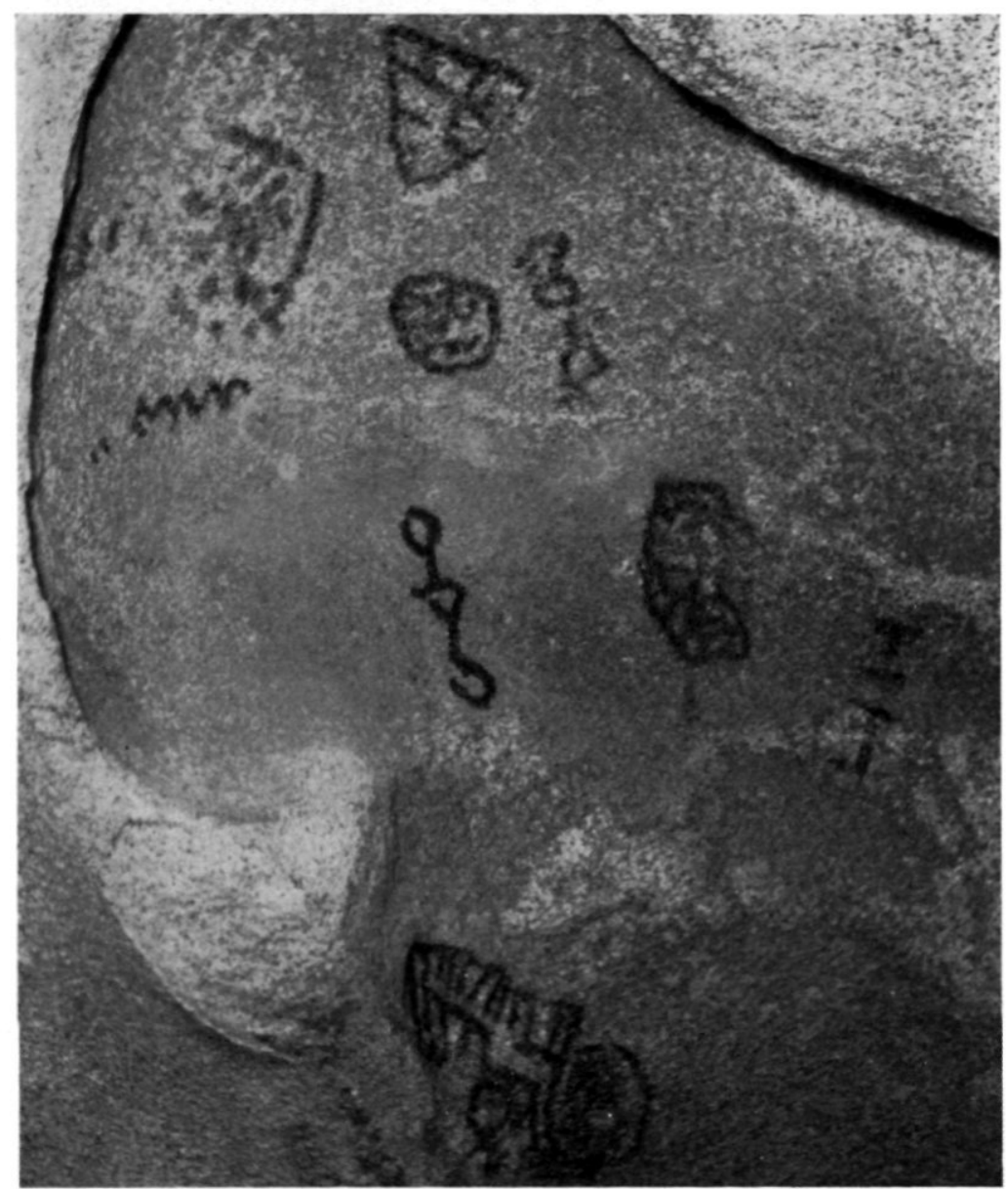

Fig. 54. De roodachtige rotstekeningen uit de verweringsholte van het op de vorige afbeelding voorkomende (achterste) diorietblok van Casibari, Aruba (A 20; vgl. Fig. I6).

Fig. 54. Reddish drawings from the right-hand boulder of the two shown in the previous picture (A 20: cf. Fig. I6). 


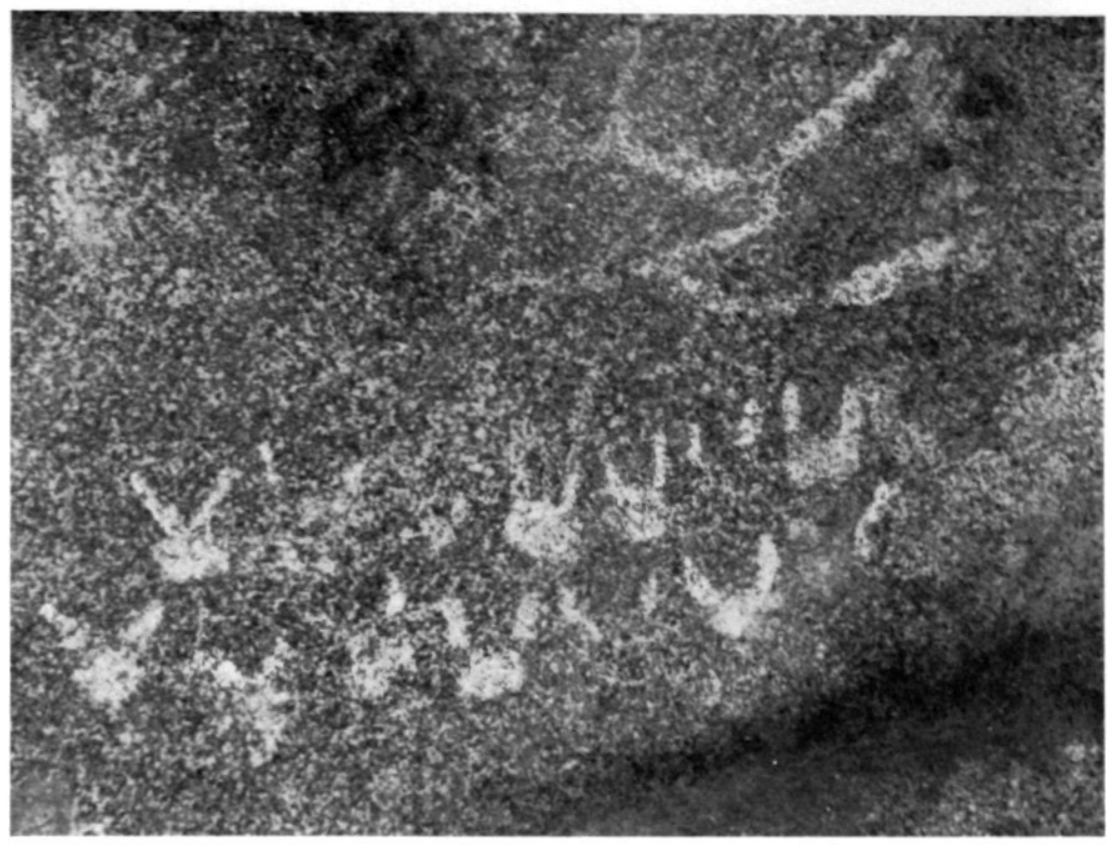

Fig. 55. De witte 'konijnekoppen' van een diorietblok bij Shabururi, Aruba (A 23; vgl. Fig. 17).

Fig. 55. Whitish paintings on diorite, which look like a double row of 'rabbits' heads' near Shabururi (A 23; cf. Fig. I7).

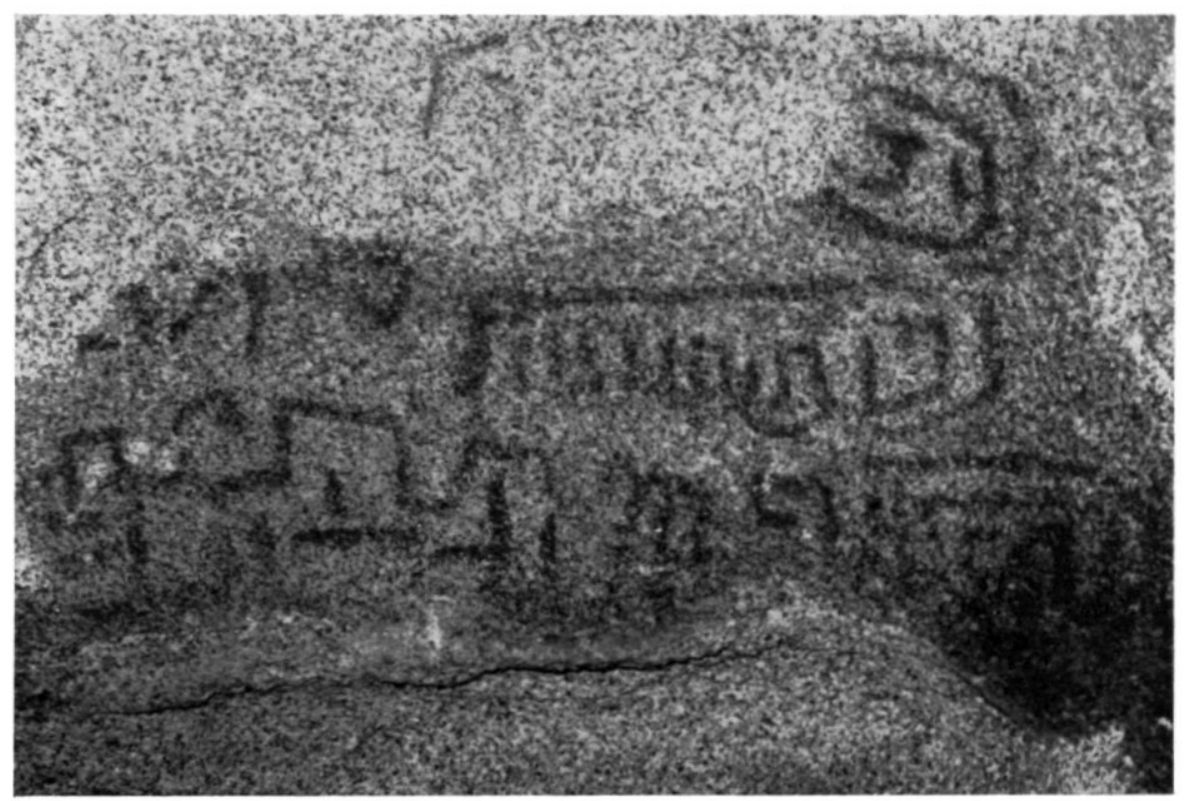

Fig. 56. Roodbruine tekeningen bij Siribana, Aruba (A 26; vgl. Fig. 19), die reeds door PINART (1890) werden geschetst, en in die tijd reeds op eenzelfde wijze waren beschadigd door afschilferen van het diorietgesteente.

Fig. 56. Ornamental design on diorite at Siribana (A 26; cf. Fig. 19), which was sketched by PINART in 1890 and even then was already damaged by desintegration of the rock. 

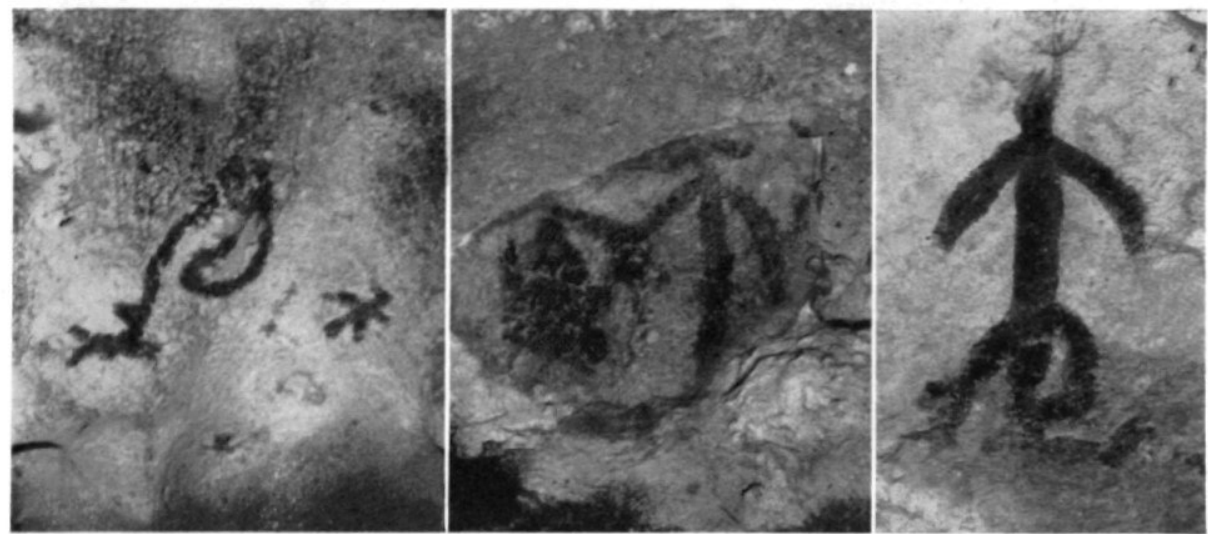

Fig. 57. Enkele roodbruine tekens uit het westelijke deel van een diep abri van het kalksteenterras beoosten de Grot van Quadirikiri, Aruba (A 28 ; vgl.

Fig. $2 \mathbf{I}-22, g, k, i)$.

Fig. 57. Reddish-brown figures from the western part of a limestone abri, east of the cave of Quadirikiri (A 28; cf. Figs. 2I-22, $g, k, j$ ).

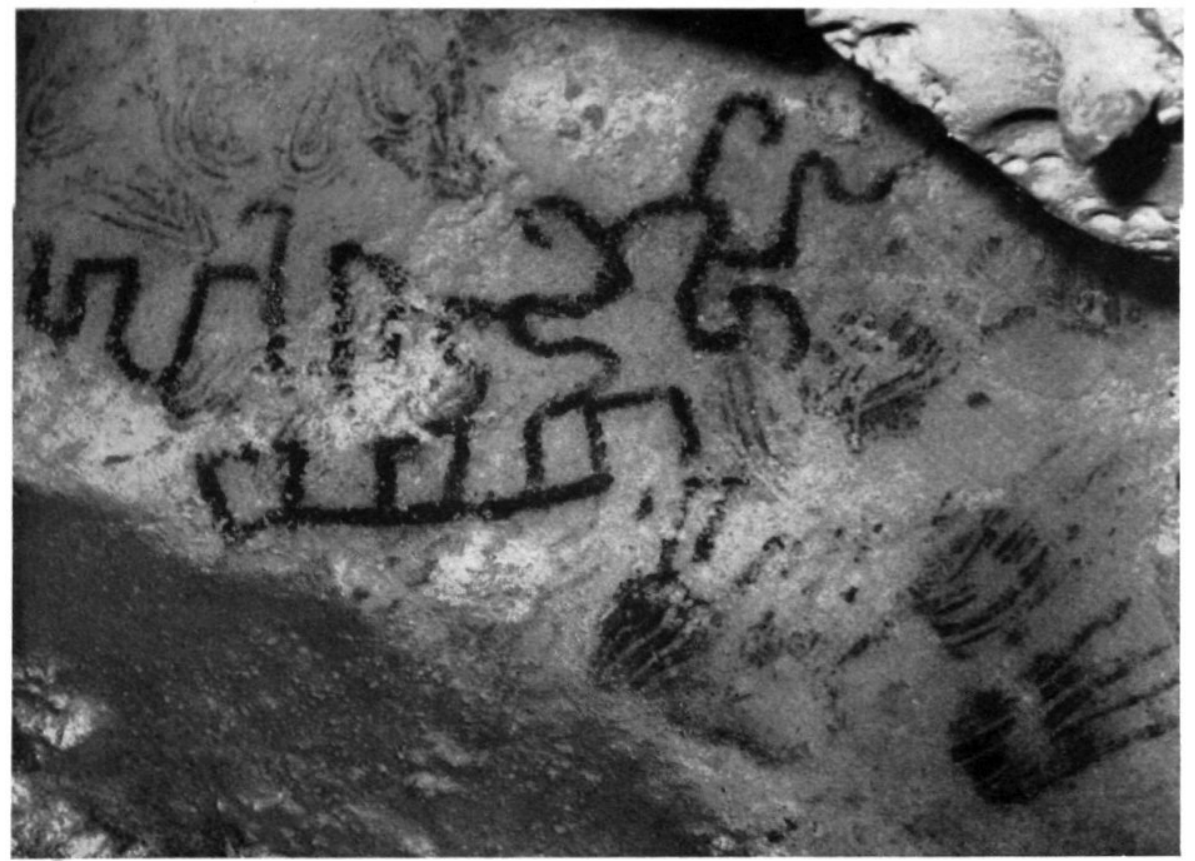

Fig. 58. Roodbruin ornament met handafdrukken en enkele nog onverklaarde afdrukken in het oostelijk deel van een diep abri in het kalksteenterras beoosten de Grot van Quadirikiri, Aruba (A 27 ; vgl. Fig. 20).

Fig. 58. Linear rock drawings, together with prints of hands and some still unexplained marks, from the eastein part of a limestone abri, east of the cave of Quadirikiri (A 27 ; cf. Fig. 20). 


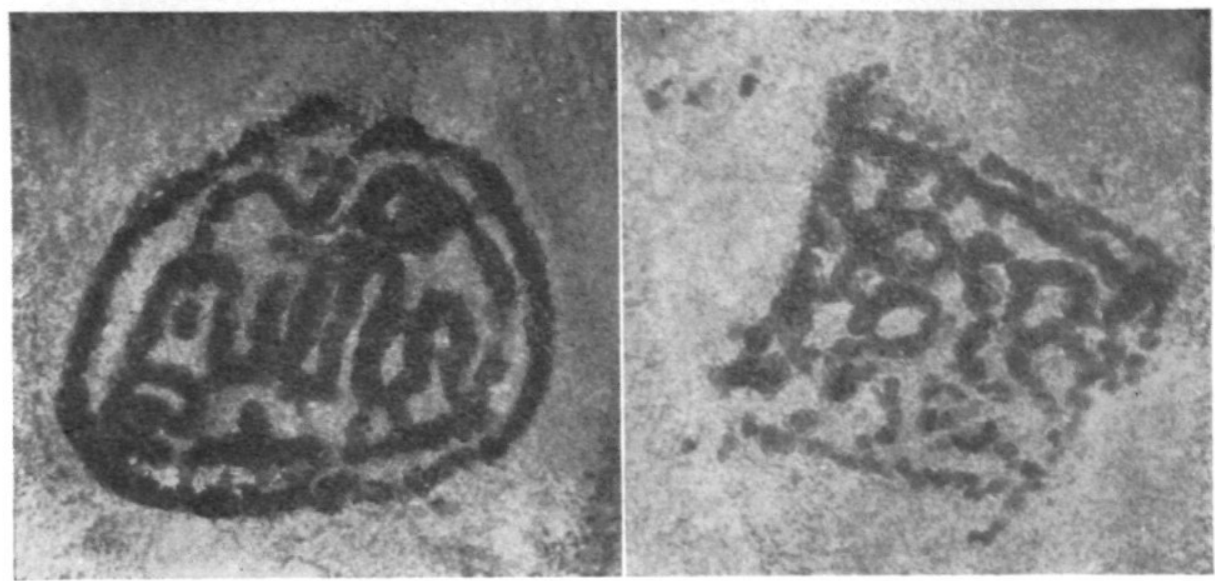

Fig. 59. Tekeningen van een diorietblok van Macuarima, bij Santa Cruz, Aruba (A 29; vgl. Fig. 24).

Fig. 59. Drawings on a diorite boulder at Macuarima, near Santa Cruz (A 29; cf. Fig. 24).

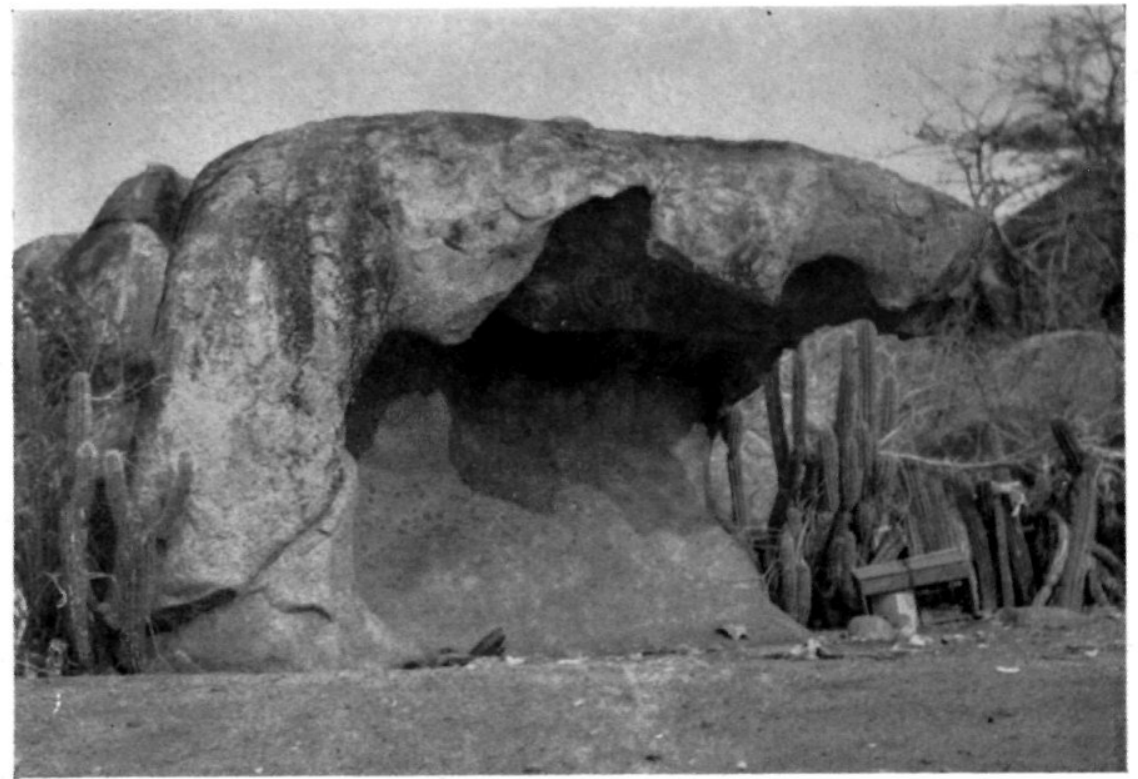

Fig. 6o. Een op het Westen sterk uitgehold diorietblok in de buurtschap Paraguaná, Aruba (A 30), vindplaats van belangwekkende rotstekeningen. Op het dak, vlak boven de ingang ziet men nog sporen van de in Fig. 62 afgebeelde witte ornamenten.

Fig. 6o. A diorite rock at Paraguaná (A 30), which is strongly hollowed out on its west side, where very interesting petrographs have been found (cf. Fig. 62). 


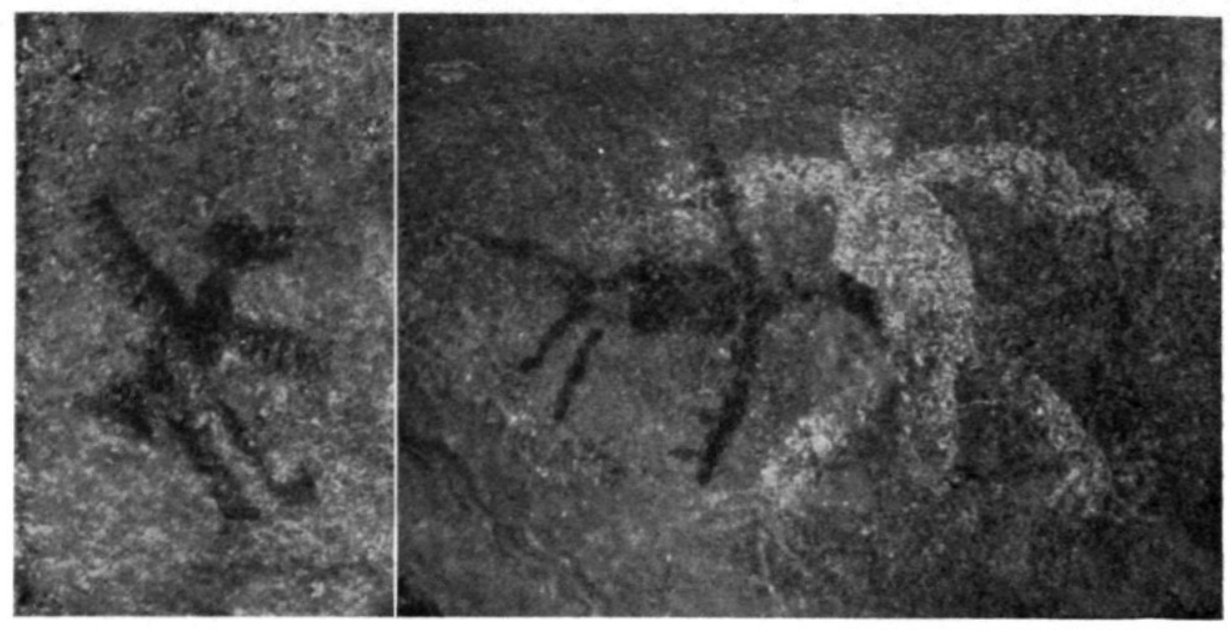

Fig. 6r. Een roodbruine 'vogel', een bruine en witte 'schildpad' of 'leguaan' op het diorietblok van Paraguaná, Aruba (A 30; vgl. Fig. 25).

Fig. 61. A reddish-brown figure of a bird and two drawings of turtles or iguanas, from the site at Paraguaná (A 30; cf. Fig. 25).
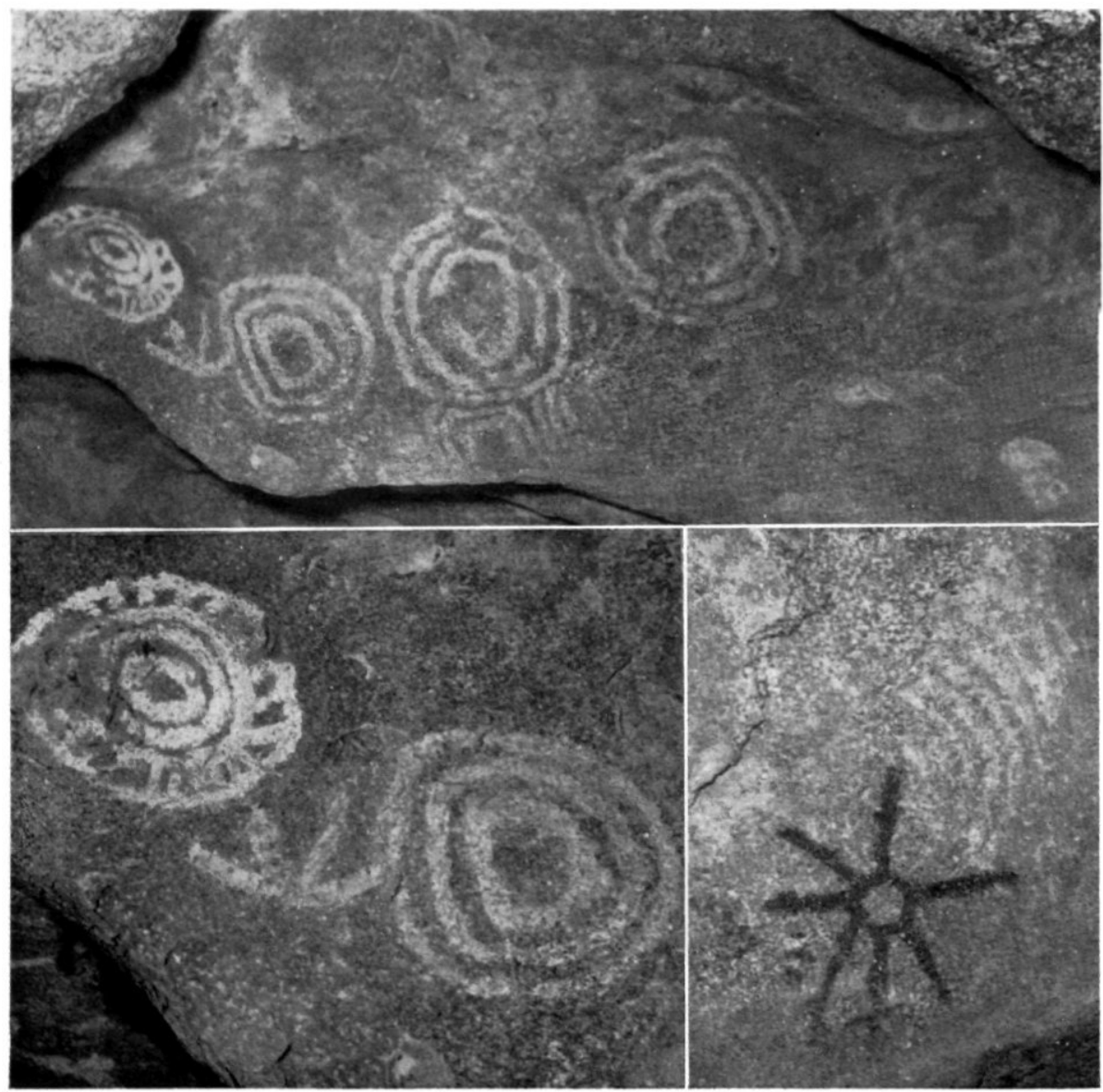

Fig. 62. Witte concentrische versieringen en een roodbruine 'zon' van dezelfde vindplaats te Paraguaná, Aruba (A 30; vgl. Fig. 25-26).

Fig. 62. Decorations in white and reddish brown, from the same site at Paraguaná (A 30; cf. Figs. 25-26). 


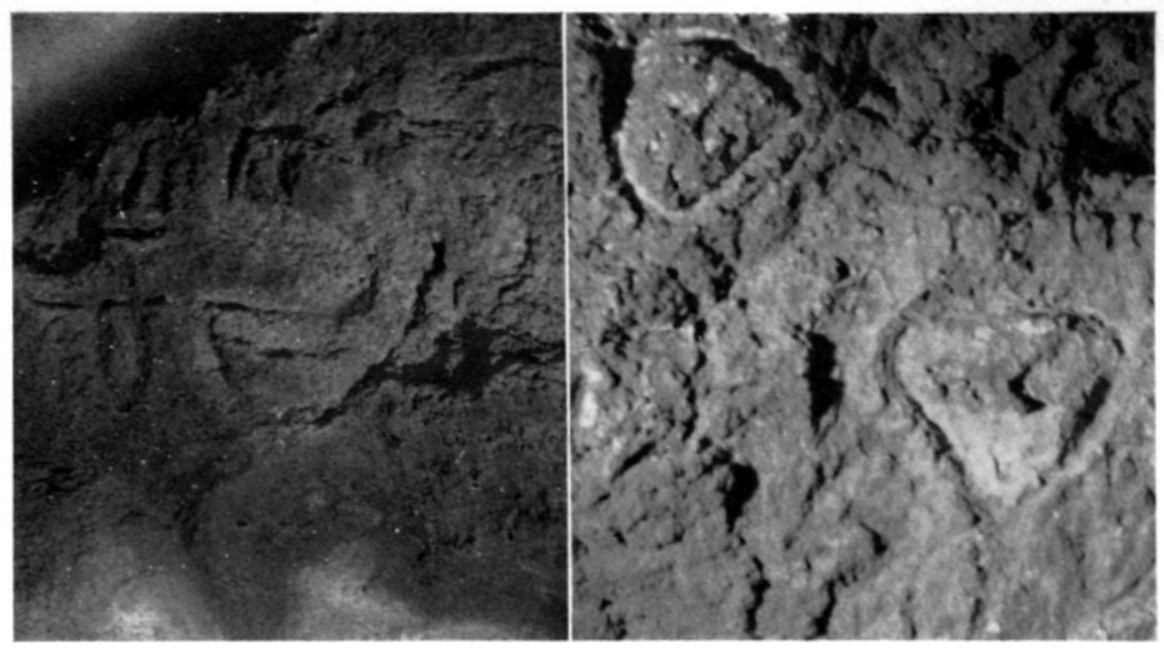

Fig. 63. Onduidelijke reliëfs in verweerde druipsteen van het abri van Hato, Curaçao (C 4 ; vgl. Fig. $27-28,64^{-65}$, en I, fig. 20-2I). Foto P. A. v. D. WERF.

Fig. 63. Petroglyphs in weathered dripstone in the abri of Hato (C 4 : cf. Figs. $27-28,64-65$, and I, figs. 20-2I).
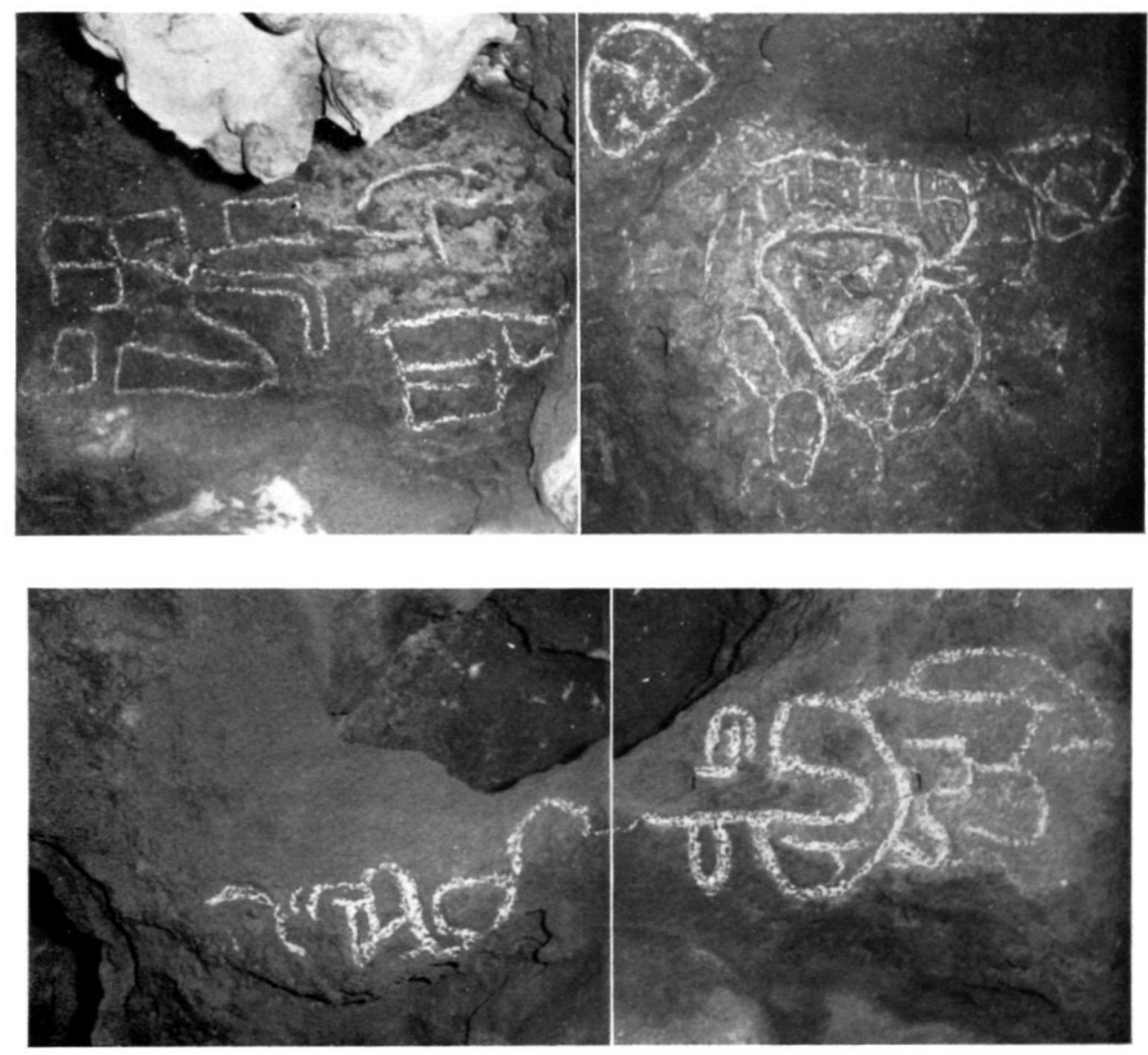

Fig. 64-65. De reliëfs van Hato, Curaçao ( $\mathrm{C}_{4}$ ), besmeerd met krijt om ze beter te kunnen fotograferen (vgl. Fig. 27-28, 63, en I, fig. 20-2I).

Figs. $64-65$. The Hato petroglyphs, traced with chalk to make them more conspicuous (cf. Figs. $27-28,63$, and I, figs. 20-2I). 


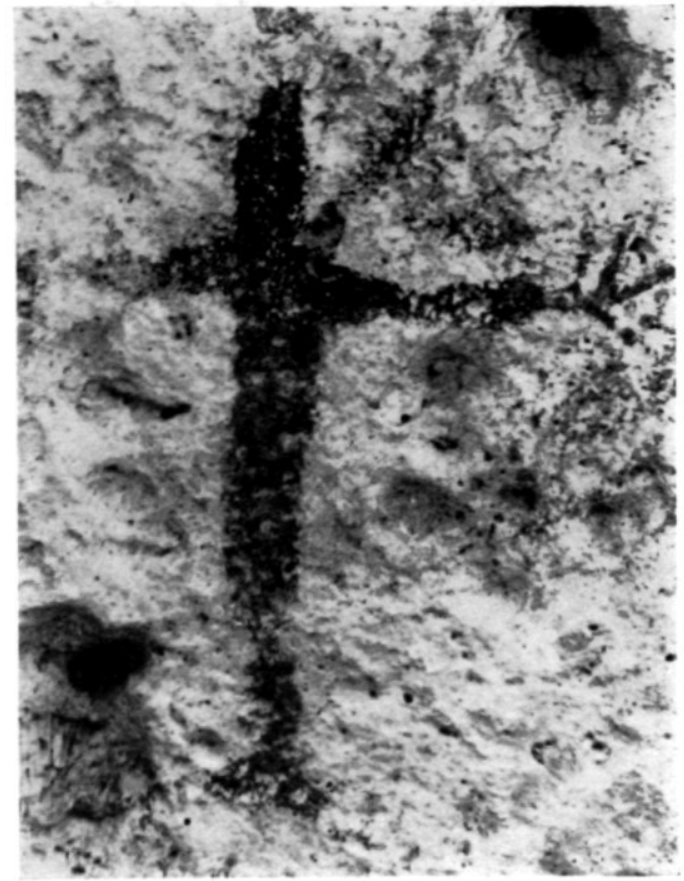

Fig. 66. Rocdbruine petrografie van Santa Martha, Curaçao (C II; vgl. Fig. 33). Foto P. A. VAN DER WERF.

Fig. 66. Reddish-brown petrograph at Santa Martha (C II ; vgl. Fig. 33).

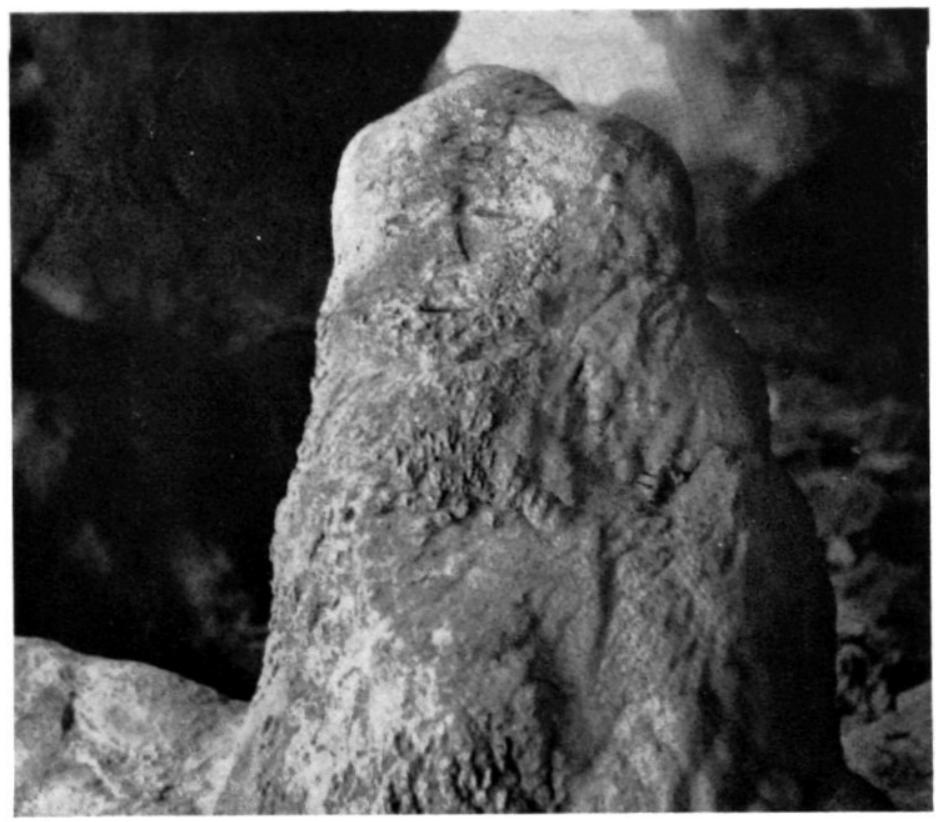

Fig. 67. Petroglyph uit de grot van Koraal Tabak, Curaçao (C I4; vgl. Fig. $38)$ : een verweerde stalagmiet waarin gelaatstrekken met z.g. koffieboonogen zijn uitgehouwen. Het behaarde uiterlijk, met de 'baard' wordt veroorzaakt door het natuurlijk oppervlak van de druipsteen. Foto C. J. DU Ry. Fig. 67. Petroglyph in the cave of Koraal Tabak, Curaçao ( $\mathrm{C}_{14}$; cf. Fig. 38): a weathered stalagmite bearing carved traces of a face with 'coffee-bean eyes'. 
been incorporated in this part, together with a few of the author's own observations.

In 1885 Father van KoolwIJ K wrote (Part I, p. II) that he had already discovered Indian inscriptions in no less than twenty-seven places in Aruba. At first we were inclined to assume that most of these must since have disappeared. But TJON SIE FAT's investigations have shown that such is not the case (see Fig. $\mathbf{r}$ ). His fieldwork yielded more results than we had dared to hope, and is so extremely well documented that a word of tribute must not be omitted here.

In 1958 the Natural Science Study Group issued a birthday calendar, Prenda Antiyano, in which the calendar sheets were decorated with drawings of a large number of petrographs (including some unknown ones from Santa Martha and Spelonk). A survey of the Curaçao rock drawings is given in HARTog's extensive work on Curafao, which appeared a few months ago.

In his report on his archaeological study trips Zwischen Peru und Mexico, published in 1959, HANS FERIZ, honorary associate of the Royal Tropical Institute, Amsterdam, devotes no less than $3^{8}$ pages (and three folding plates) to Aruba and Bonaire. The part of this book relating to the Aruban rock drawings has been included verbatim for completeness' sake, and without comments, in the present publication (p. 84-91, Figs. 2-4). FERIz's ready interpretations will undoubtedly be more to the taste of many people than the cautious reserve which the compiler of this record has deemed advisable up till now with regard to the petrographs of the Netherlands Antilles.

SITES IN ARUBA (A)

Piedra Plat (3) and Arikok (7-12)

TJON SIE FAT took photographs using red-insensitive film, whereby he obtained pictures of the rock drawings which were clearer than those obtained hitherto. Furthermore, some new discoveries were made at the locality of Arikok.

Babijn (13-14), Paradera (16-19), Casibari (20), Seroe Noka (21), Shabururi (22, 23), Siribana (24-26), Macuarima (29) and Paraguaná (30)

Careful examination of the cavities produced by weathering in the boulders strewn over the diorite landscape yielded a remarkable series of drawings in the form of both purely ornamental decorations and figures which might be interpreted as symbols, and representations of animals. Many of these have been badly damaged by desquamation of the rock; in fact, it may be assumed that what we now see are the last remains of pictures on a much larger scale, which must formerly have covered the rocks in many places.

Here again it was possible to perceive that at sundry points various drawings - perhaps dating from different times - have been executed beside or on top of each other.

Especially striking are the white figures of Shabururi, which resemble rabbits' heads (23 c), the frog motif of Paradera (18 a), the upraised arms of Siribana $(25 d)$, the red-brown and white animal figures of Paraguaná (3० $a-c)$, and the other drawings in white at this last site. 
Boca Grandi (15) and Quadirikiri (27-28)

Of the drawings which were found outside the quartz-diorite area, some figures in two deep abris east of the well-known cave of Quadirikiri are particularly worthy of attention.

SITES IN CURAÇAO (c)

Hato (4)

The petroglyphs of Hato have proved to be much more numerous than was suspected. They are engraved in (now weathered) dripstone (i.e., not in hard limestone). The 'face with headdress' strikes us as being a not wholly convincing representation; the nose and mouth depend largely on the imagination of the beholder, and the eyes are holes which make an impression of not being entirely artificial.

Santa Martha (1 1-12) and St. Jan (13)

The first rock drawings found on the southwest coast of Curaçao were discovered by Messrs. G. H. Barneveld and J. G. DE Jong in the elevated abris hollowed by the surf in the limestone terrace on both sides of Santa Martha Bay. These discoveries were soon followed by that of the paintings in the abri of St. Jan, all the details of which are given here on the authority of J. G. DE JONG.

Koraal Tabak (14)

Finally, Mrs. J. G. DE JoNG made the very unexpected discovery, in a small cave devoid of drawings near the entrance to St. Joris Bay, of a weathered stalagmite in which a distinct mouth, a nose, and 'coffee-bean eyes' had been cut. Despite its 'modern' characteristics, the entire piece of 'sculpture' gives the impression of also having been made by the former Indian inhabitants of Curaçao. 